\title{
Which Type of Pincer Complexes is Thermodynamically More Stable? \\ Understanding the Structures and Relative Bond Strengths of Group 10 Metal Complexes Supported by Benzene-Based PYCYP Pincer Ligands
}

Fei Fang, ${ }^{\dagger, \S}$ Jia-Xin Kang, ${ }^{\dagger, \S}$ Cong-Qiao Xu, Jiarui Chang, ${ }^{\dagger}$ Jie Zhang, ${ }^{, \dagger}$ Shujun Li, ${ }^{\dagger}$ and Xuenian Chen ${ }^{*}, \dagger$

\begin{abstract}
${ }^{\dagger}$ Henan Key Laboratory of Boron Chemistry and Advanced Energy Materials, Key Laboratory of Green Chemical Media and Reactions, Ministry of Education, Collaborative Innovation Centre of Henan Province for Green Manufacturing of Fine Chemicals, School of Chemistry and Chemical Engineering, Henan Normal University, Xinxiang, Henan 453007, China. *E-mail: jie.zhang@htu.edu.cn, xnchen@htu.edu.cn.

'Department of Chemistry, Southern University of Science and Technology, Shenzhen, Guangdong, 518055, China.

${ }^{\star}$ College of Chemistry and Molecular Engineering, Zhengzhou University Zhengzhou, Henan 450001, China.

${ }^{\S}$ These authors contributed equally to this work.
\end{abstract}

\section{Table of Contents}

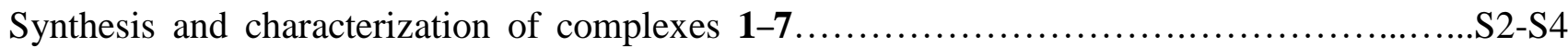

NMR and IR spectra of complexes 1-7 (Figures S1-S24) ................................S5-S16

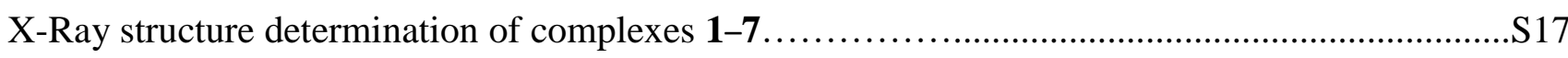

Thermal ellipsoid plots of complexes 1-7 (Figures S25-S31) .............................. 20

Summary of crystal data and structure refinement for complexes 1-7 (Tables S1 and S2).....S21-S22

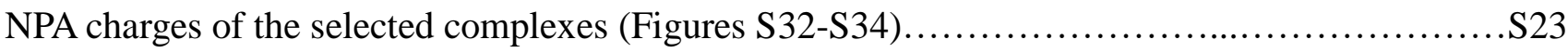

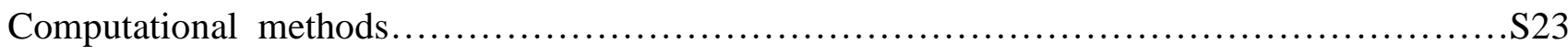

Electron density and potential energy density at bond critical point for selected complexes.......S24

Views of molecular structure for some selected complexes.........................S25-S34

The Cartesian Coordinates of Optimized Structures................................ S35-S49

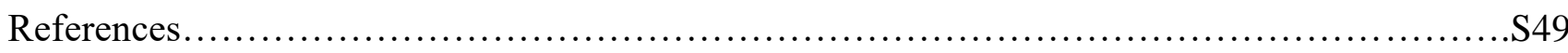


Synthesis and characterization $\left[2,6-\left(\mathrm{R}_{2} \mathrm{PNH}\right)_{2} \mathrm{C}_{6} \mathrm{H}_{3}\right] \mathrm{MX}\left(\mathrm{M}=\mathrm{Ni}, \mathrm{Pd} ; \mathrm{R}={ }^{\mathrm{t} B u},{ }^{\mathrm{i}} \mathrm{Pr} ; \mathrm{X}=\mathrm{SH}, \mathrm{SPh}\right.$, SBn)

\section{General Information}

All of the synthesis and manipulations were performed under a nitrogen atmosphere. Solvents were degassed and dried before use. NMR spectra were recorded on Bruker Advance spectrometers (600 or $400 \mathrm{MHz}$ ). Chemical shift values were referenced internally to the residual solvent resonances for ${ }^{1} \mathrm{H}$ and ${ }^{13} \mathrm{C}\left\{{ }^{1} \mathrm{H}\right\}$ NMR spectra; chemical shift values of ${ }^{31} \mathrm{P}\left\{{ }^{1} \mathrm{H}\right\}$ NMR spectra were referenced externally to $85 \% \mathrm{H}_{3} \mathrm{PO}_{4}(0 \mathrm{ppm})$. The starting nickel and palladium complexes $\left[2,6-\left({ }^{\mathrm{t}} \mathrm{Bu}{ }_{2} \mathrm{PNH}\right)_{2} \mathrm{C}_{6} \mathrm{H}_{3}\right] \mathrm{NiCl}, \quad\left[2,6-\left({ }^{\mathrm{t}} \mathrm{Bu}{ }_{2} \mathrm{PNH}\right)_{2} \mathrm{C}_{6} \mathrm{H}_{3}\right] \mathrm{PdCl}, \quad$ and $\quad\left[2,6-\left({ }^{\mathrm{i}} \mathrm{Pr}_{2} \mathrm{PNH}\right)_{2} \mathrm{C}_{6} \mathrm{H}_{3}\right] \mathrm{NiCl}$ were prepared by following the published procedures. ${ }^{\mathrm{S} 1}$

Synthesis of $\left[2,6-\left({ }^{t} \mathrm{Bu}{ }_{2} \mathrm{PNH}\right)_{2} \mathrm{C}_{6} \mathrm{H}_{3}\right] \mathrm{NiSH}(\mathbf{1})$

A mixture of $\left[2,6-\left({ }^{\mathrm{t}} \mathrm{Bu}_{2} \mathrm{PNH}\right)_{2} \mathrm{C}_{6} \mathrm{H}_{3}\right] \mathrm{NiCl}(490 \mathrm{mg}, 1 \mathrm{mmol}), \mathrm{NaSH}(280 \mathrm{mg}, 5 \mathrm{mmol}), \mathrm{THF}(20$ $\mathrm{mL})$ and methyl alcohol $(5 \mathrm{~mL})$ was stirred under a reflux condition for $12 \mathrm{~h}$. Upon cooling to room temperature, the volatiles were removed under vacuum. The residue was extracted with toluene $(3 \times$ $10 \mathrm{~mL}$ ) and filtered through a pad of Celite. The combined filtrates was concentrated to $10 \mathrm{~mL}$ and crystallized at room temperature to produce complex $\mathbf{1}$ as an orange solid (424 $\mathrm{mg}, 87 \%$ yield). ${ }^{1} \mathrm{H}$ NMR (600 MHz, DMSO-d6, $\delta$ ): 6.48 (t, 1H, ArH, $\left.J_{\mathrm{H}-\mathrm{H}}=7.6 \mathrm{~Hz}\right), 6.27$ (s, 2H, NH), 5.95 (d, 2H, ArH, $\left.J_{\mathrm{H}-\mathrm{H}}=7.6 \mathrm{~Hz}\right), 1.35-1.37\left(\mathrm{~m}, 36 \mathrm{H}, \mathrm{C}\left(\mathrm{CH}_{3}\right) 3\right),-1.79\left(\mathrm{t}, 1 \mathrm{H}, \mathrm{S} H, J_{\mathrm{H}-\mathrm{P}}=17.9 \mathrm{~Hz}\right) .{ }^{13} \mathrm{C}\left\{{ }^{1} \mathrm{H}\right\} \mathrm{NMR}(151$ MHz, DMSO-d6, $\delta$ ): 160.0 (t, $\left.\operatorname{ArC}, J_{\mathrm{C}-\mathrm{P}}=13.9 \mathrm{~Hz}\right), 125.9(\mathrm{~s}, \mathrm{ArC}), 99.7(\mathrm{~s}, \operatorname{Ar} C), 37.7\left(\mathrm{t}, C\left(\mathrm{CH}_{3}\right) 3\right.$, $\left.J_{\mathrm{C}-\mathrm{P}}=8.9 \mathrm{~Hz}\right), 28.5\left(\mathrm{~s}, \mathrm{C}\left(\mathrm{CH}_{3}\right) 3\right) .{ }^{31} \mathrm{P}\left\{{ }^{1} \mathrm{H}\right\}$ NMR $(243 \mathrm{MHz}$, benzene-d6, $\delta): 119.0$ (s). FTIR $(\mathrm{KBr}$ disc): $3330\left(\mathrm{~s}, v_{\mathrm{N}-\mathrm{H}}\right), 2608\left(\mathrm{w}, v_{\mathrm{S}-\mathrm{H}}\right) \mathrm{cm}^{-1}$. Anal. Calcd for $\mathrm{C}_{22} \mathrm{H}_{42} \mathrm{~N}_{2} \mathrm{NiP}_{2} \mathrm{~S}: \mathrm{C}, 54.23 ; \mathrm{H}, 8.69$. Found: C, 54.29; H, 8.54.

Synthesis of [2,6-( $\left.\left.{ }^{\mathrm{B}} \mathrm{Bu}{ }_{2} \mathrm{PNH}\right)_{2} \mathrm{C}_{6} \mathrm{H}_{3}\right] \mathrm{NiSPh}(2)$

Complex 2 was synthesized similarly by reacting $\left[2,6-\left({ }^{\mathrm{t}} \mathrm{Bu}_{2} \mathrm{PNH}\right)_{2} \mathrm{C}_{6} \mathrm{H}_{3}\right] \mathrm{NiCl}$ with 3 equiv. of $\mathrm{NaSPh}$ in THF/MeOH (4:1). The reaction mixture was refluxed for $20 \mathrm{~h}$. Complex 2 was isolated as a red solid in $82 \%$ yield. ${ }^{1} \mathrm{H}$ NMR $\left(600 \mathrm{MHz}\right.$, methanol- $\left.d_{4}, \delta\right): 7.45-7.46(\mathrm{~m}, 2 \mathrm{H}, \mathrm{Ar} H), 6.92-6.94$ $(\mathrm{m}, 2 \mathrm{H}, \operatorname{Ar} H), 6.81-6.84(\mathrm{~m}, 1 \mathrm{H}, \operatorname{ArH}), 6.61-6.63(\mathrm{~m}, 1 \mathrm{H}, \operatorname{Ar} H), 5.99\left(\mathrm{~d}, 2 \mathrm{H}, \operatorname{Ar} H, J_{\mathrm{H}-\mathrm{H}}=7.7 \mathrm{~Hz}\right)$, 
1.38-1.41 (m, 36H, C(CH3)3). ${ }^{13} \mathrm{C}\left\{{ }^{1} \mathrm{H}\right\} \mathrm{NMR}\left(151 \mathrm{MHz}\right.$, methanol- $\left.d_{4}, \delta\right): 162.0\left(\mathrm{t}, \quad \operatorname{Ar} C, J_{\mathrm{C}-\mathrm{P}}=13.9\right.$ $\mathrm{Hz}), 148.8\left(\mathrm{t}, \operatorname{Ar} C, J_{\mathrm{C}-\mathrm{P}}=3.0 \mathrm{~Hz}\right), 135.4(\mathrm{~s}, \operatorname{Ar} C), 128.5(\mathrm{~s}, \operatorname{Ar} C), 128.3(\mathrm{~s}, \operatorname{Ar} C), 122.6(\mathrm{~s}, \operatorname{Ar} C)$, $122.0\left(\mathrm{t}, \quad \operatorname{ArC}, J_{\mathrm{C}-\mathrm{P}}=18.6 \mathrm{~Hz}\right), 100.8\left(\mathrm{t}, \operatorname{Ar} C, J_{\mathrm{C}-\mathrm{P}}=6.5 \mathrm{~Hz}\right), 39.2\left(\mathrm{t}, C\left(\mathrm{CH}_{3}\right) 3, J_{\mathrm{C}-\mathrm{P}}=8.7 \mathrm{~Hz}\right), 29.5(\mathrm{t}$, $\left.\mathrm{C}\left(\mathrm{CH}_{3}\right)_{3}, J_{\mathrm{C}-\mathrm{P}}=2.8 \mathrm{~Hz}\right) .{ }^{31} \mathrm{P}\left\{{ }^{1} \mathrm{H}\right\} \mathrm{NMR}\left(243 \mathrm{MHz}\right.$, methanol- $\left.d_{4}, \delta\right): 110.2$ (s). Anal. Calcd for $\mathrm{C}_{28} \mathrm{H}_{46} \mathrm{~N}_{2} \mathrm{NiP}_{2} \mathrm{~S}:$ C, 59.69; H, 8.23. Found: C, 59.80; H, 8.21.

Synthesis of [2,6-( $\left.\left.{ }^{\mathrm{B}} \mathrm{Bu} \mathrm{P}_{2} \mathrm{PNH}\right)_{2} \mathrm{C}_{6} \mathrm{H}_{3}\right] \mathrm{NiSBn}(3)$

Complex 3 was synthesized similarly by reacting [2,6-( $\left.\left.{ }^{\mathrm{t}} \mathrm{Bu}{ }_{2} \mathrm{PNH}\right)_{2} \mathrm{C}_{6} \mathrm{H}_{3}\right] \mathrm{NiCl}$ with 3 equiv. of $\mathrm{NaSBn}$ in THF/MeOH (4:1). The reaction mixture was refluxed for $12 \mathrm{~h}$. Complex 3 was isolated as a red solid in $79 \%$ yield. ${ }^{1} \mathrm{H}$ NMR $\left(600 \mathrm{MHz}\right.$, methanol- $\left.d_{4}, \delta\right): 7.25-7.26(\mathrm{~m}, 2 \mathrm{H}, \mathrm{Ar} H), 7.18-7.20$ (m, 2H, ArH), 7.09-7.11 (m, 1H, ArH), 6.61-6.64 (m, 1H, ArH), 5.99 (d, 2H, ArH, JH-H = 7.7 Hz), $5.73(\mathrm{~s}, 2 \mathrm{H}, \mathrm{NH}), 3.46(\mathrm{~s}, 2 \mathrm{H}, \mathrm{SCH}), 1.51-1.54\left(\mathrm{~m}, 36 \mathrm{H}, \mathrm{C}\left(\mathrm{CH}_{3}\right) 3\right) .{ }^{13} \mathrm{C}\left\{{ }^{1} \mathrm{H}\right\} \mathrm{NMR}(151 \mathrm{MHz}$, methanol- $\left.d_{4}, \delta\right): 161.9\left(\mathrm{t}, \operatorname{ArC}, J_{\mathrm{C}-\mathrm{P}}=13.9 \mathrm{~Hz}\right), 146.7(\mathrm{~s}, \operatorname{Ar} C), 129.5(\mathrm{~s}, \operatorname{Ar} C), 129.2(\mathrm{~s}, \operatorname{ArC}), 128.9$

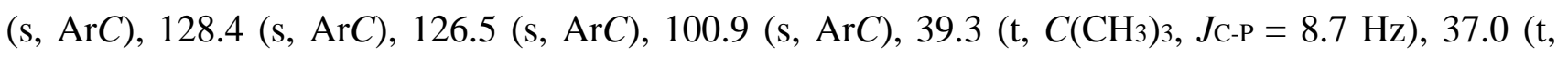
$\left.\mathrm{SCH}_{2}, J_{\mathrm{C}-\mathrm{P}}=3.3 \mathrm{~Hz}\right), 29.7\left(\mathrm{t}, \mathrm{C}\left(\mathrm{CH}_{3}\right) 3, J_{\mathrm{C}-\mathrm{P}}=2.7 \mathrm{~Hz}\right) .{ }^{31} \mathrm{P}\left\{{ }^{1} \mathrm{H}\right\}$ NMR $(243 \mathrm{MHz}$, benzene-d6, $\delta)$ : 112.6 (s). Anal. Calcd for $\mathrm{C}_{29} \mathrm{H}_{48} \mathrm{~N}_{2} \mathrm{NiP}_{2} \mathrm{~S}$ : C, 60.32; H, 8.38. Found: C, 60.50; H, 8.47.

\section{Synthesis of $\left[2,6-\left({ }^{t} \mathrm{Bu}{ }_{2} \mathrm{PNH}\right)_{2} \mathrm{C}_{6} \mathrm{H}_{3}\right] \mathrm{PdSH}(4)$}

Complex 4 was synthesized similarly by reacting [2,6-( $\left.\left.{ }^{\mathrm{t}} \mathrm{Bu}{ }_{2} \mathrm{PNH}\right)_{2} \mathrm{C}_{6} \mathrm{H}_{3}\right] \mathrm{PdCl}$ with 5 equiv. of $\mathrm{NaSH}$ in $\mathrm{THF} / \mathrm{MeOH}$ (4:1). The reaction mixture was stirred at room temperature for $2 \mathrm{~h}$. Complex 4 was isolated as a luminous yellow solid in $88 \%$ yield. ${ }^{1} \mathrm{H} \mathrm{NMR}\left(600 \mathrm{MHz}, \mathrm{CD}_{3} \mathrm{CN}, \delta\right): 6.64(\mathrm{t}, 1 \mathrm{H}$, $\left.\operatorname{Ar} H, J_{\mathrm{H}-\mathrm{H}}=7.8 \mathrm{~Hz}\right), 6.16\left(\mathrm{~d}, 2 \mathrm{H}, \operatorname{ArH}, J_{\mathrm{H}-\mathrm{H}}=7.8 \mathrm{~Hz}\right), 5.09(\mathrm{~s}, 2 \mathrm{H}, \mathrm{NH}), 1.34-1.36(\mathrm{~m}, 36 \mathrm{H}$, $\left.\mathrm{C}\left(\mathrm{CH}_{3}\right)_{3}\right),-1.53\left(\mathrm{t}, 1 \mathrm{H}, \mathrm{SH}, J_{\mathrm{H}-\mathrm{P}}=9.9 \mathrm{~Hz}\right) .{ }^{13} \mathrm{C}\left\{{ }^{1} \mathrm{H}\right\} \mathrm{NMR}\left(151 \mathrm{MHz}, \mathrm{CD}_{3} \mathrm{CN}, \delta\right): 158.9\left(\mathrm{t}, \quad \operatorname{ArC}, J_{\mathrm{C}-\mathrm{P}}\right.$ $=11.3 \mathrm{~Hz}), 131.3(\mathrm{~s}, \operatorname{ArC}), 127.2(\mathrm{~s}, \operatorname{Ar} C), 101.8\left(\mathrm{t}, \operatorname{Ar} C, J_{\mathrm{C}-\mathrm{P}}=8.8 \mathrm{~Hz}\right), 39.1\left(\mathrm{t}, C\left(\mathrm{CH}_{3}\right) 3, J_{\mathrm{C}-\mathrm{P}}=9.4\right.$ $\mathrm{Hz}), 28.7$ (t, $\left.\mathrm{C}\left(\mathrm{CH}_{3}\right) 3, J_{\mathrm{C}-\mathrm{P}}=3.5 \mathrm{~Hz}\right) .{ }^{31} \mathrm{P}\left\{{ }^{1} \mathrm{H}\right\} \mathrm{NMR}\left(243 \mathrm{MHz}, \mathrm{CD}_{3} \mathrm{CN}, \delta\right.$ ): 124.0 (s). Anal. Calcd for $\mathrm{C}_{22} \mathrm{H}_{42} \mathrm{~N}_{2} \mathrm{P}_{2} \mathrm{PdS}$ : C, 49.39; H, 7.91. Found: C, 49.48; H, 8.00.

\section{Synthesis of [2,6-( $\left.\left.{ }^{t} \mathrm{Bu} \mathrm{u}_{2} \mathrm{PNH}\right)_{2} \mathrm{C}_{6} \mathrm{H}_{3}\right] \mathrm{PdSPh}(5)$}

Complex 5 was synthesized similarly by reacting [2,6-( $\left.\left.{ }^{\mathrm{t}} \mathrm{Bu}_{2} \mathrm{PNH}\right)_{2} \mathrm{C}_{6} \mathrm{H}_{3}\right] \mathrm{PdCl}$ with 3 equiv. of $\mathrm{NaSPh}$ in $\mathrm{THF} / \mathrm{MeOH}(4: 1)$. The reaction mixture was stirred at room temperature for $2 \mathrm{~h}$. Complex 5 was isolated was isolated as a yellow solid in $80 \%$ yield. ${ }^{1} \mathrm{H}$ NMR $\left(600 \mathrm{MHz}\right.$, methanol- $\left.d_{4}, \delta\right): 7.44$ 
$\left(\mathrm{d}, 2 \mathrm{H}, \quad \operatorname{Ar} H, J_{\mathrm{H}-\mathrm{H}}=8.0 \mathrm{~Hz}\right), 6.94\left(\mathrm{t}, 2 \mathrm{H}, \mathrm{ArH}, J_{\mathrm{H}-\mathrm{H}}=7.7 \mathrm{~Hz}\right), 6.82\left(\mathrm{t}, 1 \mathrm{H}, \operatorname{ArH}, J_{\mathrm{H}-\mathrm{H}}=7.3 \mathrm{~Hz}\right), 6.69$ $\left(\mathrm{t}, 1 \mathrm{H}, \mathrm{ArH}, J_{\mathrm{H}-\mathrm{H}}=7.7 \mathrm{~Hz}\right), 6.18\left(\mathrm{~d}, 2 \mathrm{H}, \mathrm{ArH}, J_{\mathrm{H}-\mathrm{H}}=8.0 \mathrm{~Hz}\right), 5.92(\mathrm{~s}, 2 \mathrm{H}, \mathrm{NH}), 1.34-1.37(\mathrm{~m}, 36 \mathrm{H}$,

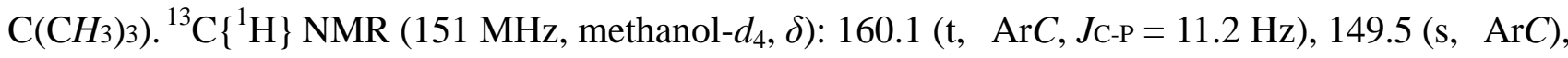
$134.9(\mathrm{~s}, \operatorname{ArC}), 129.2\left(\mathrm{t}, \operatorname{Ar} C, J_{\mathrm{C}-\mathrm{P}}=11.0 \mathrm{~Hz}\right), 128.3(\mathrm{~s}, \operatorname{Ar} C), 128.0(\mathrm{~s}, \operatorname{ArC}), 122.4(\mathrm{~s}, \operatorname{Ar} C), 101.8$ $\left(\mathrm{t}, \operatorname{ArC}, J_{\mathrm{C}-\mathrm{P}}=8.8 \mathrm{~Hz}\right), 39.6\left(\mathrm{t}, C\left(\mathrm{CH}_{3}\right) 3, J_{\mathrm{C}-\mathrm{P}}=9.0 \mathrm{~Hz}\right), 29.2\left(\mathrm{t}, \mathrm{C}\left(\mathrm{CH}_{3}\right)_{3}, J_{\mathrm{C}-\mathrm{P}}=3.2 \mathrm{~Hz}\right) .{ }^{31} \mathrm{P}\left\{{ }^{1} \mathrm{H}\right\}$ NMR $\left(243 \mathrm{MHz}\right.$, methanol- $\left.d_{4}, \delta\right)$ : 118.1 (s). Anal. Calcd for $\mathrm{C}_{28} \mathrm{H}_{46} \mathrm{~N}_{2} \mathrm{P}_{2} \mathrm{PdS}$ : C, 55.03; H, 7.59. Found: C, 54.90; H, 7.44.

\section{Synthesis of $\left[2,6-\left({ }^{t} \mathrm{Bu} u_{2} \mathrm{PNH}\right)_{2} \mathrm{C}_{6} \mathrm{H}_{3}\right] \mathrm{PdSBn}(\mathbf{6})$}

Complex 6 was synthesized similarly from the reaction of $\left[2,6-\left({ }^{\mathrm{t}} \mathrm{Bu}_{2} \mathrm{PNH}\right)_{2} \mathrm{C}_{6} \mathrm{H}_{3}\right] \mathrm{PdCl}$ with 3 equiv. of NaSBn in THF/MeOH (4:1). The reaction mixture was stirred at room temperature for $2 \mathrm{~h}$. Complex 6 was isolated as a red solid in $84 \%$ yield. ${ }^{1} \mathrm{H}$ NMR $\left(600 \mathrm{MHz}\right.$, methanol- $\left.d_{4}, \delta\right): 7.29-7.31$ (m, 2H, ArH), 7.17-7.20 (m, 2H, ArH), 7.07-7.09 (m, 1H, ArH), 6.64-6.67 (m, 1H, ArH), 6.16 (d, $\left.2 \mathrm{H}, \mathrm{ArH}, J_{\mathrm{H}-\mathrm{H}}=7.7 \mathrm{~Hz}\right), 3.67(\mathrm{~s}, 2 \mathrm{H}, \mathrm{SCH}), 1.44-1.46(\mathrm{~m}, 36 \mathrm{H}, \mathrm{C}(\mathrm{CH}) 3) .{ }^{13} \mathrm{C}\left\{{ }^{1} \mathrm{H}\right\} \mathrm{NMR}(151$ MHz, methanol- $\left.d_{4}, \delta\right): 160.0\left(\mathrm{t}, \operatorname{Ar} C, J_{\mathrm{C}-\mathrm{P}}=11.2 \mathrm{~Hz}\right), 147.3(\mathrm{~s}, \operatorname{Ar} C), 130.0(\mathrm{~s}, \operatorname{Ar} C), 129.6(\mathrm{~s}, \operatorname{Ar} C)$, $128.9(\mathrm{~s}, \operatorname{ArC}), 127.9(\mathrm{~s}, \operatorname{Ar} C), 126.4(\mathrm{~s}, \operatorname{Ar} C), 101.8\left(\mathrm{t}, \operatorname{ArC}, J_{\mathrm{C}-\mathrm{P}}=8.2 \mathrm{~Hz}\right), 39.7\left(\mathrm{t}, C\left(\mathrm{CH}_{3}\right) 3, J_{\mathrm{C}-\mathrm{P}}=\right.$ $10.0 \mathrm{~Hz}$ ), 36.9 (s, SCH2), 29.3 (t, $\left.\mathrm{C}\left(\mathrm{CH}_{3}\right) 3, J_{\mathrm{C}-\mathrm{P}}=3.4 \mathrm{~Hz}\right) .{ }^{31} \mathrm{P}\left\{{ }^{1} \mathrm{H}\right\} \mathrm{NMR}\left(243 \mathrm{MHz}\right.$, methanol- $d_{4}, \delta$ ): 118.9(s). Anal. Calcd for $\mathrm{C}_{29} \mathrm{H}_{48} \mathrm{~N}_{2} \mathrm{PdP}_{2} \mathrm{~S}$ : C, 55.72; H, 7.74. Found: C, 55.91; H, 7.75.

\section{Synthesis of [2,6-( $\left.\left.{ }^{i} \mathrm{Pr}_{2} \mathrm{PNH}\right)_{2} \mathrm{C}_{6} \mathrm{H}_{3}\right] \mathrm{PdSH}$ (7)}

Complex 7 was synthesized similarly from the reaction of $\left[2,6-\left({ }^{\mathrm{i}} \mathrm{Pr}_{2} \mathrm{PNH}\right)_{2} \mathrm{C}_{6} \mathrm{H}_{3}\right] \mathrm{PdCl}$ with 5 equiv. of $\mathrm{NaSH}$ in THF. The reaction mixture was refluxed for $12 \mathrm{~h}$. Complex 7 was isolated as a colorless solid in 91\% yield. ${ }^{1} \mathrm{H}$ NMR (600 MHz, DMSO-d6, $\left.\delta\right): 6.54\left(\mathrm{t}, 1 \mathrm{H}, \mathrm{ArH}, J_{\mathrm{H}-\mathrm{H}}=7.6 \mathrm{~Hz}\right)$, $6.34(\mathrm{~s}, 2 \mathrm{H}, \mathrm{NH}), 6.04\left(\mathrm{~d}, 2 \mathrm{H}, \mathrm{ArH}, J_{\mathrm{H}-\mathrm{H}}=7.7 \mathrm{~Hz}\right), 2.18-2.22\left(\mathrm{~m}, 4 \mathrm{H}, \mathrm{CH}\left(\mathrm{CH}_{3}\right)_{2}\right), 1.10-1.18(\mathrm{~m}$, 24H, $\left.\mathrm{CH}\left(\mathrm{CH}_{3}\right)_{2}\right),-1.95\left(\mathrm{t}, 1 \mathrm{H}, J_{\mathrm{H}-\mathrm{P}}=11.1 \mathrm{~Hz}\right) .{ }^{1} \mathrm{H}$ NMR $(600 \mathrm{MHz}$, benzene-d6, $\delta): 7.02(\mathrm{t}, 1 \mathrm{H}, \mathrm{ArH}$, $\left.J_{\mathrm{H}-\mathrm{H}}=7.7 \mathrm{~Hz}\right), 6.23\left(\mathrm{~d}, 2 \mathrm{H}, \mathrm{ArH}, J_{\mathrm{H}-\mathrm{H}}=7.7 \mathrm{~Hz}\right), 3.30(\mathrm{~s}, 2 \mathrm{H}, \mathrm{NH}), 1.82-1.89\left(\mathrm{~m}, 4 \mathrm{H}, \mathrm{CH}\left(\mathrm{CH}_{3}\right) 2\right)$, 1.25-1.29 (m, 12H, $\left.\mathrm{CH}\left(\mathrm{CH}_{3}\right) 2\right), 0.88-0.92\left(\mathrm{~m}, 12 \mathrm{H}, \quad \mathrm{CH}\left(\mathrm{CH}_{3}\right) 2\right),-1.21\left(\mathrm{t}, 1 \mathrm{H}, J_{\mathrm{H}-\mathrm{P}}=11.5 \mathrm{~Hz}\right) .{ }^{13} \mathrm{C}$ NMR (151 MHz, DMSO-d6, $\delta): 157.5$ (t, $\left.\operatorname{Ar} C, J_{\mathrm{C}-\mathrm{P}}=12.9 \mathrm{~Hz}\right), 132.0(\mathrm{~s}, \operatorname{Ar} C), 125.7(\mathrm{~s}, \operatorname{Ar} C)$, $100.9\left(\mathrm{t}, \quad \operatorname{Ar} C, J_{\mathrm{C}-\mathrm{P}}=9.0 \mathrm{~Hz}\right), 26.7\left(\mathrm{t}, \quad \mathrm{CH}\left(\mathrm{CH}_{3}\right)_{2}, J_{\mathrm{C}-\mathrm{P}}=13.4 \mathrm{~Hz}\right), 17.8\left(\mathrm{t}, \mathrm{CH}\left(\mathrm{CH}_{3}\right)_{2}, J_{\mathrm{C}-\mathrm{P}}=3.0 \mathrm{~Hz}\right)$, 16.9 (s, $\left.\mathrm{CH}\left(\mathrm{CH}_{3}\right)_{2}\right) .{ }^{31} \mathrm{P}\left\{{ }^{1} \mathrm{H}\right\}$ NMR $(243 \mathrm{MHz}$, benzene- $d 6, \delta): 116.6$ (s). FTIR (KBr disc): 3383 (m, $\left.v_{\mathrm{N}-\mathrm{H}}\right), 2560\left(\mathrm{w}, v_{\mathrm{S}-\mathrm{H}}\right) \mathrm{cm}^{-1}$. Anal. Calcd for $\mathrm{C}_{18} \mathrm{H}_{34} \mathrm{~N}_{2} \mathrm{P}_{2} \mathrm{PdS}: \mathrm{C}, 45.14 ; \mathrm{H}, 7.16$. Found: C, 45.16; H, 7.23 . 


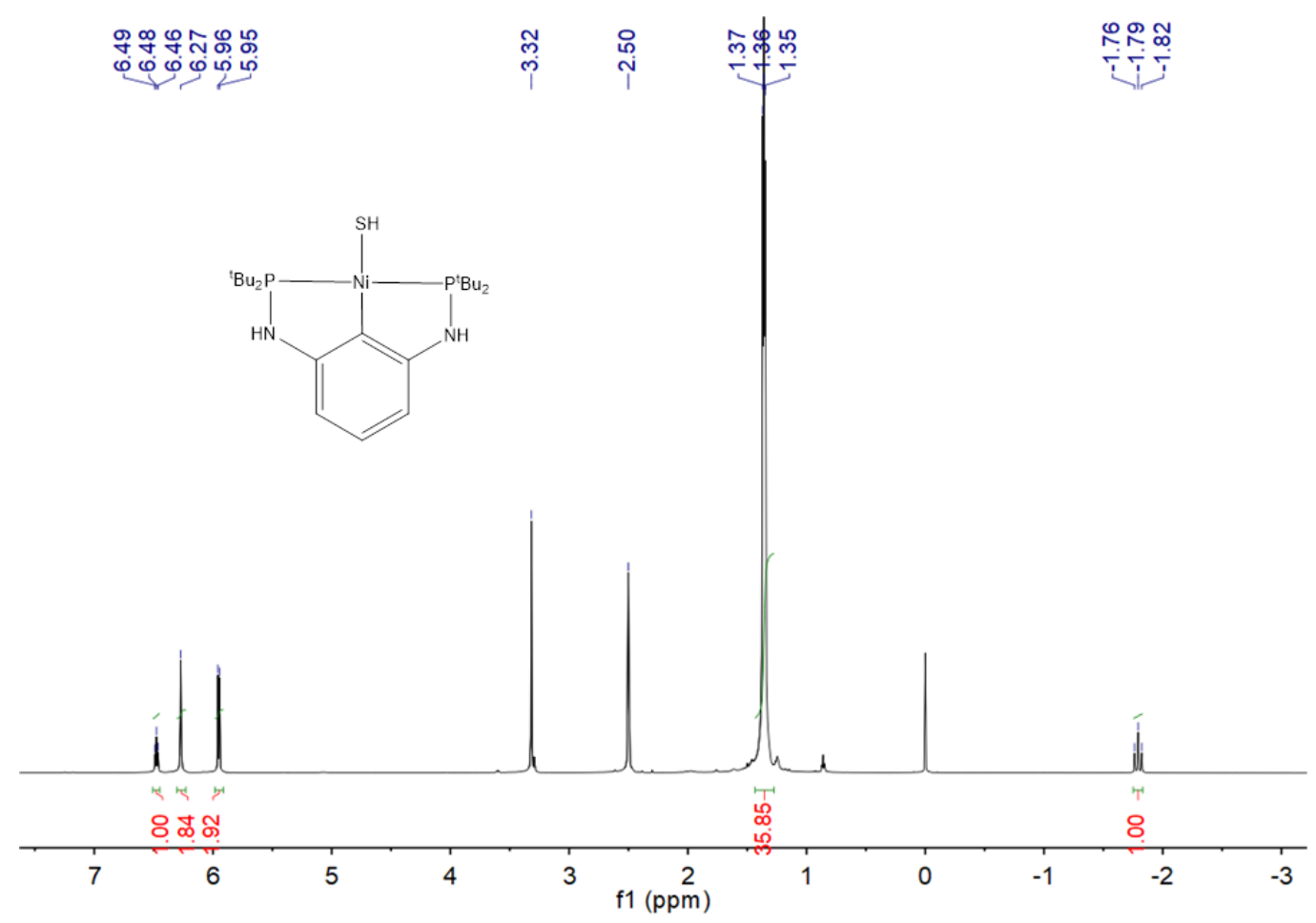

Figure S1. ${ }^{1} \mathrm{H}$ NMR spectrum of complex 1 (600 MHz, DMSO- $d_{6}$ )

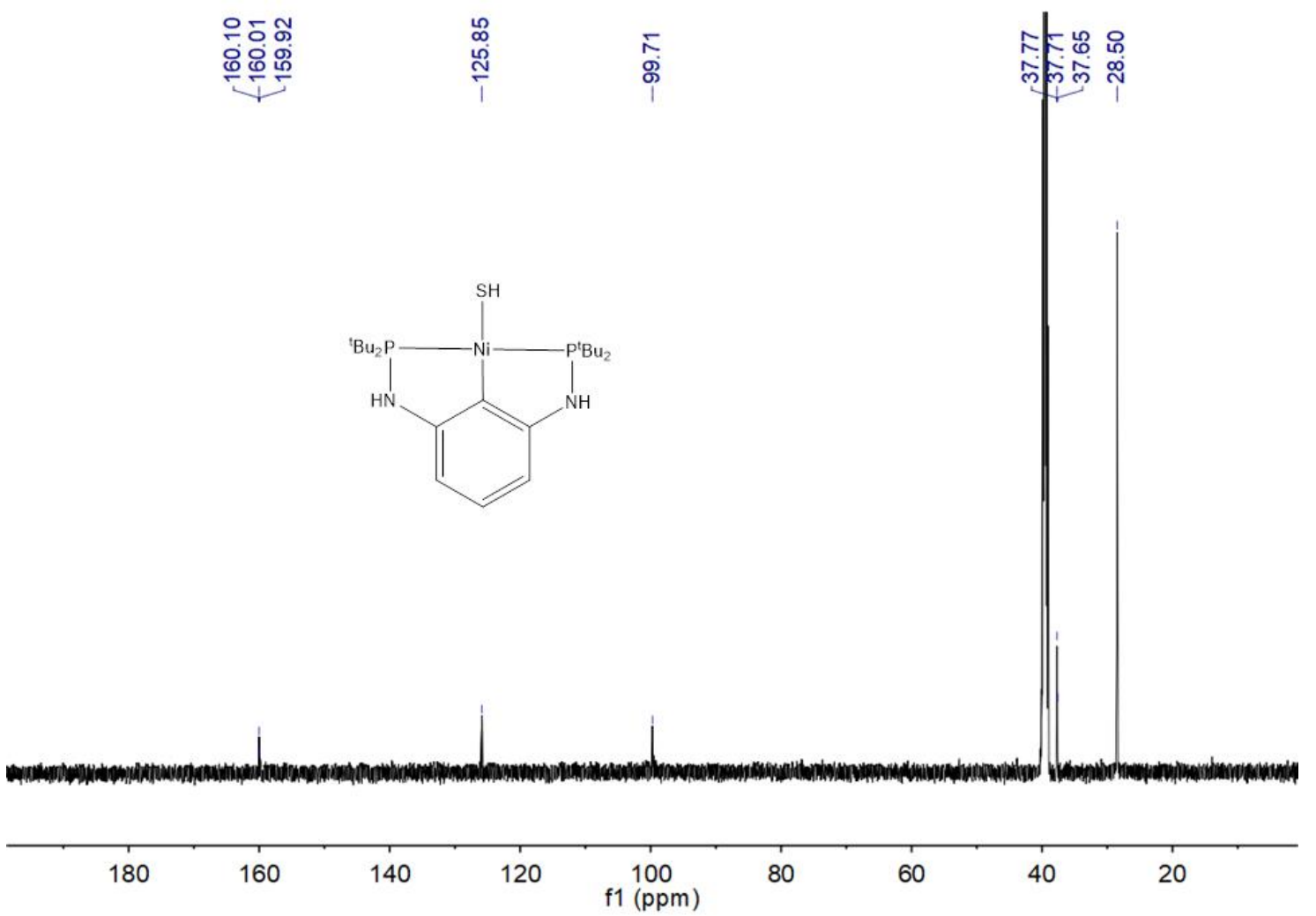

Figure S2. ${ }^{13} \mathrm{C}\left\{{ }^{1} \mathrm{H}\right\}$ NMR spectrum of complex $\mathbf{1}\left(151 \mathrm{MHz}, \mathrm{DMSO}-d_{6}\right)$ 


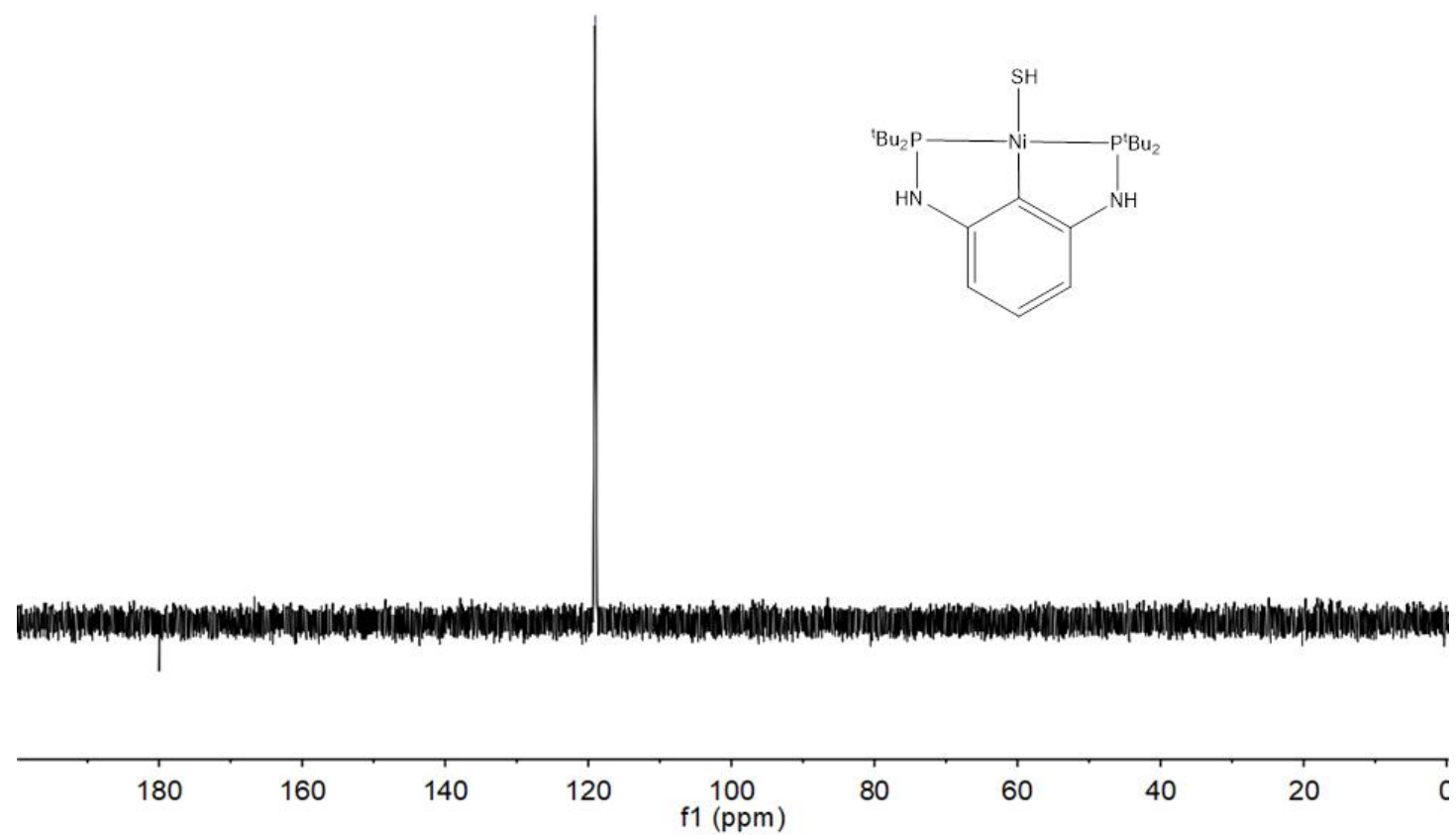

Figure S3. ${ }^{31} \mathrm{P}\left\{{ }^{1} \mathrm{H}\right\}$ NMR spectrum of complex $1(243 \mathrm{~Hz}$, benzene- $d 6)$

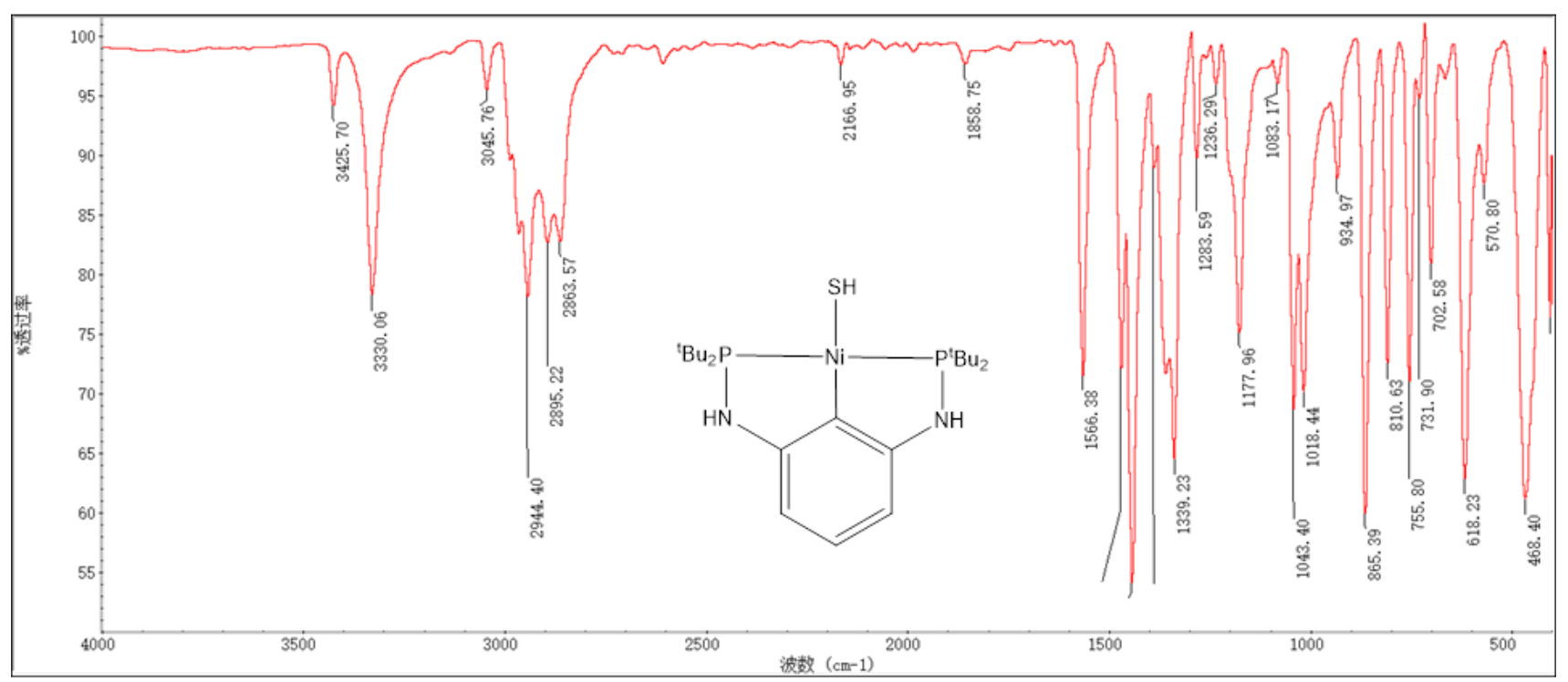

Figure S4. FTIR spectrum of complex 1 ( $\mathrm{KBr}$ disc) 


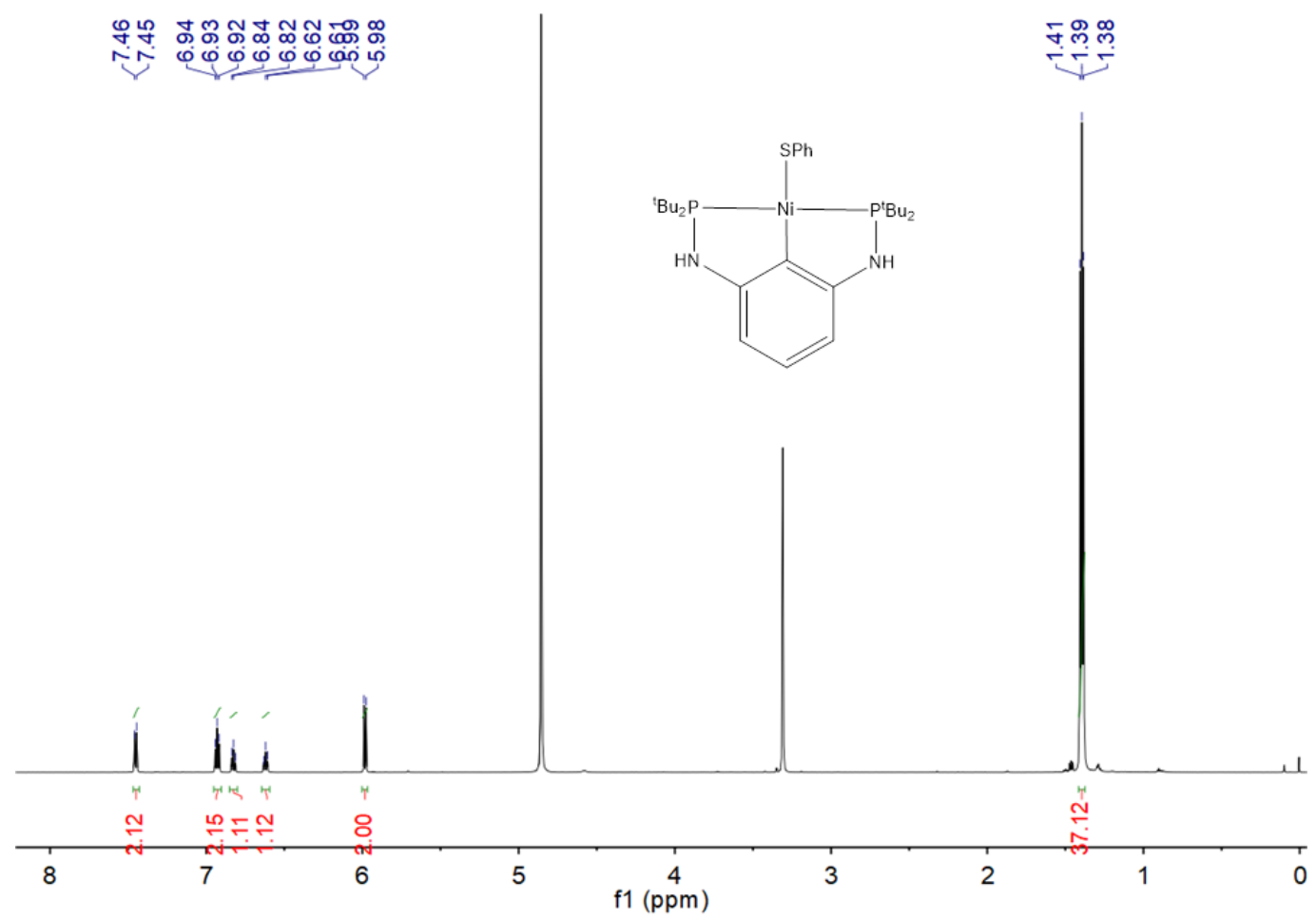

Figure S5. ${ }^{1} \mathrm{H}$ NMR spectrum of complex $2\left(600 \mathrm{MHz}\right.$, methanol- $\left.d_{4}\right)$

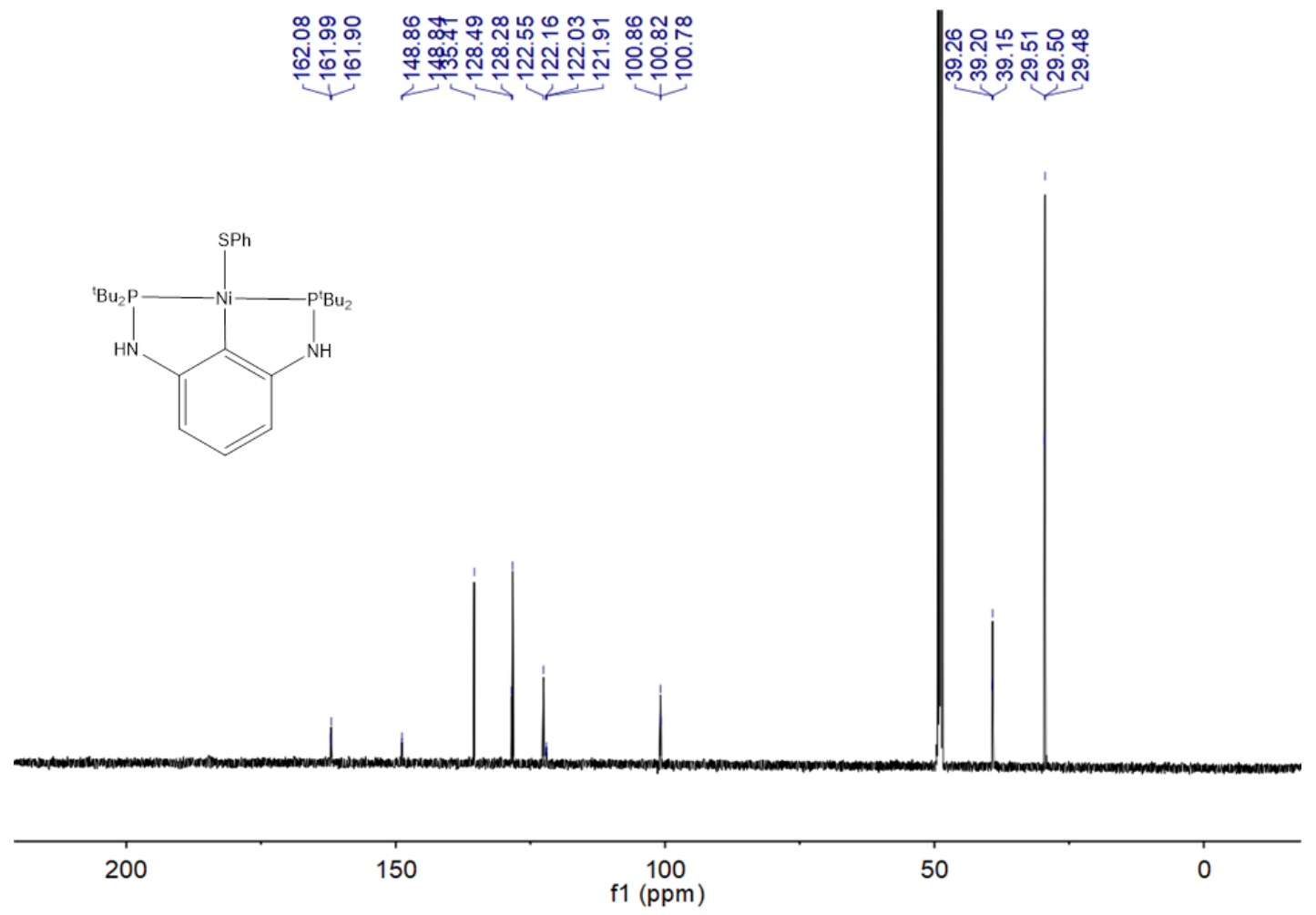

Figure S6. ${ }^{13} \mathrm{C}\left\{{ }^{1} \mathrm{H}\right\}$ NMR spectrum of complex $2\left(151 \mathrm{MHz}\right.$, methanol- $\left.d_{4}\right)$ 


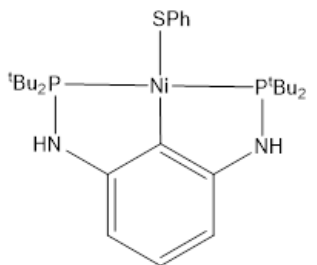

200

150

f1 (ppm)

100

50

Figure S7. ${ }^{31} \mathrm{P}\left\{{ }^{1} \mathrm{H}\right\}$ NMR spectrum of complex $2\left(243 \mathrm{~Hz}\right.$, methanol- $\left.d_{4}\right)$

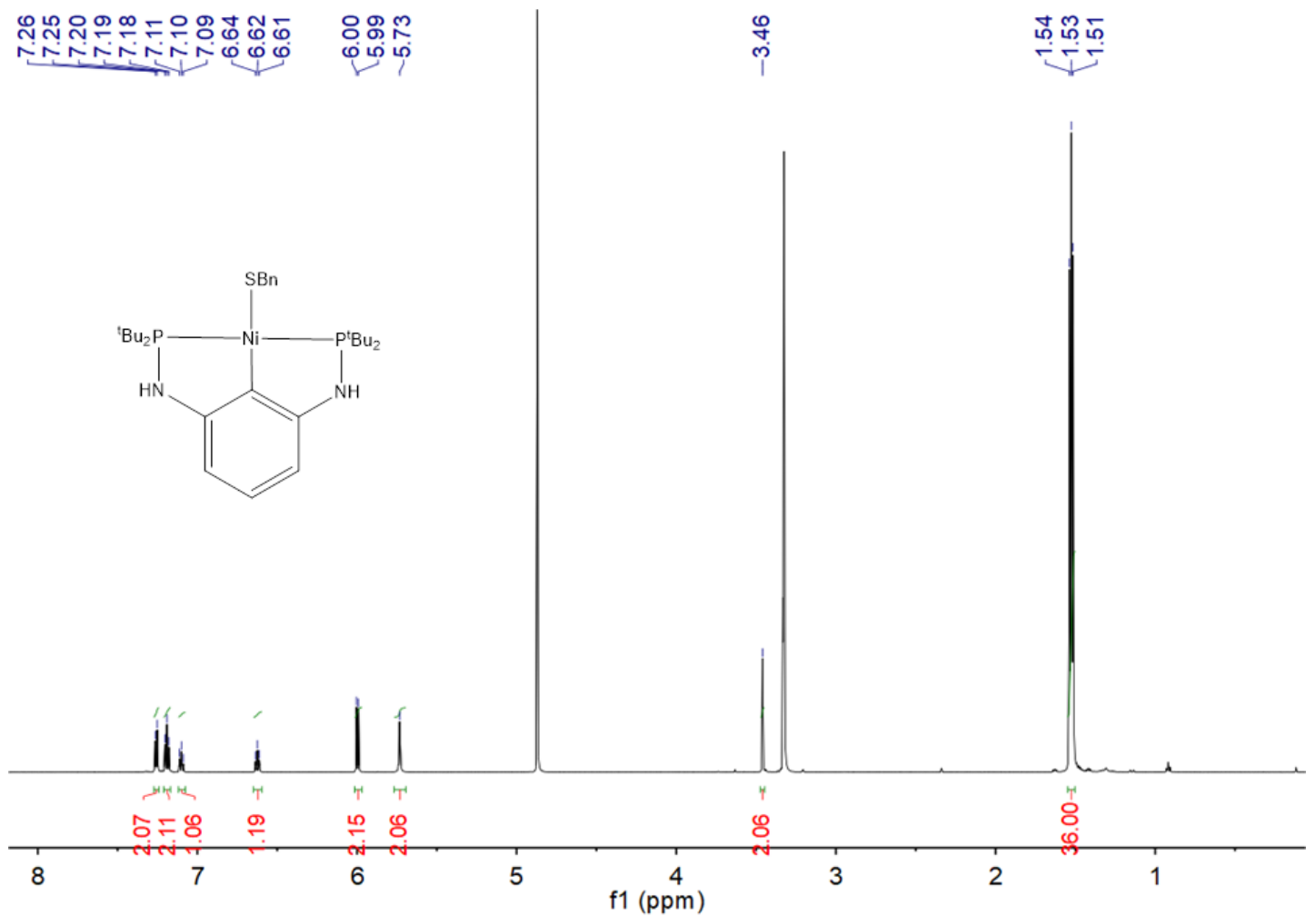

Figure S8. ${ }^{1} \mathrm{H}$ NMR spectrum of complex $3\left(600 \mathrm{MHz}\right.$, methanol- $\left.d_{4}\right)$ 


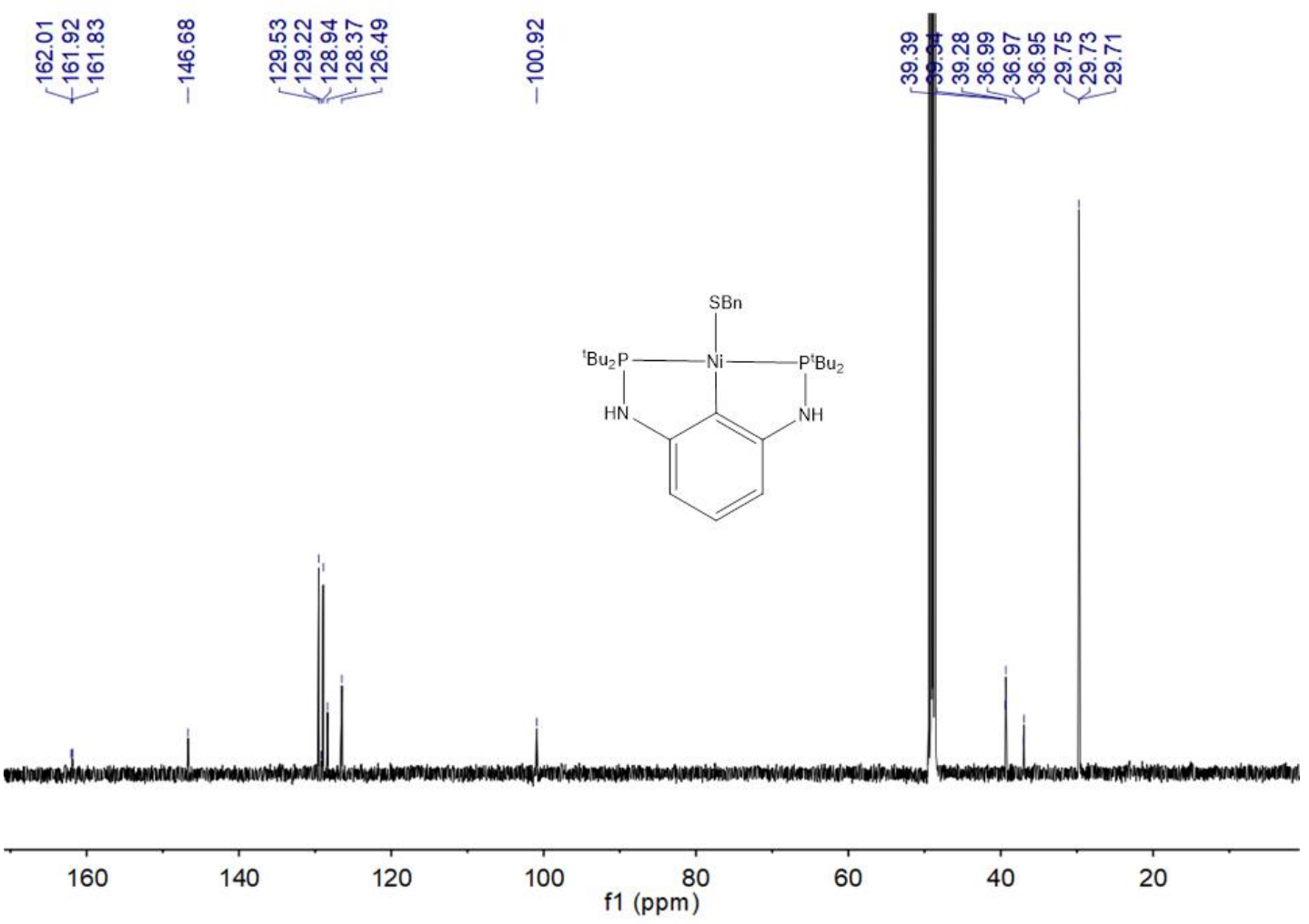

Figure S9. ${ }^{13} \mathrm{C}\left\{{ }^{1} \mathrm{H}\right\}$ NMR spectrum of complex $3\left(151 \mathrm{MHz}\right.$, methanol- $\left.d_{4}\right)$

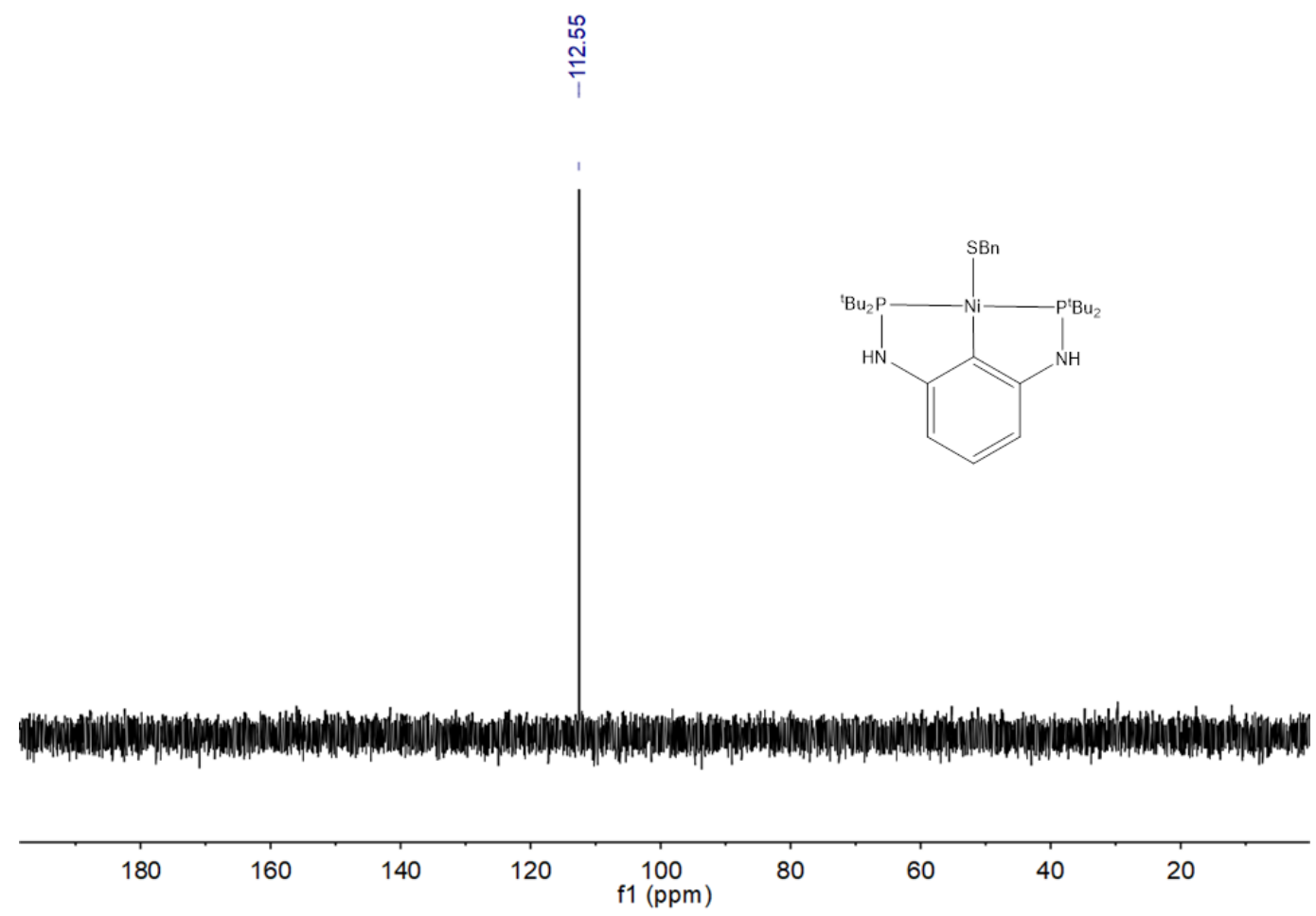

Figure S10. ${ }^{31} \mathrm{P}\left\{{ }^{1} \mathrm{H}\right\}$ NMR spectrum of complex $3\left(243 \mathrm{MHz}, \mathrm{C}_{6} \mathrm{D}_{6}\right)$ 


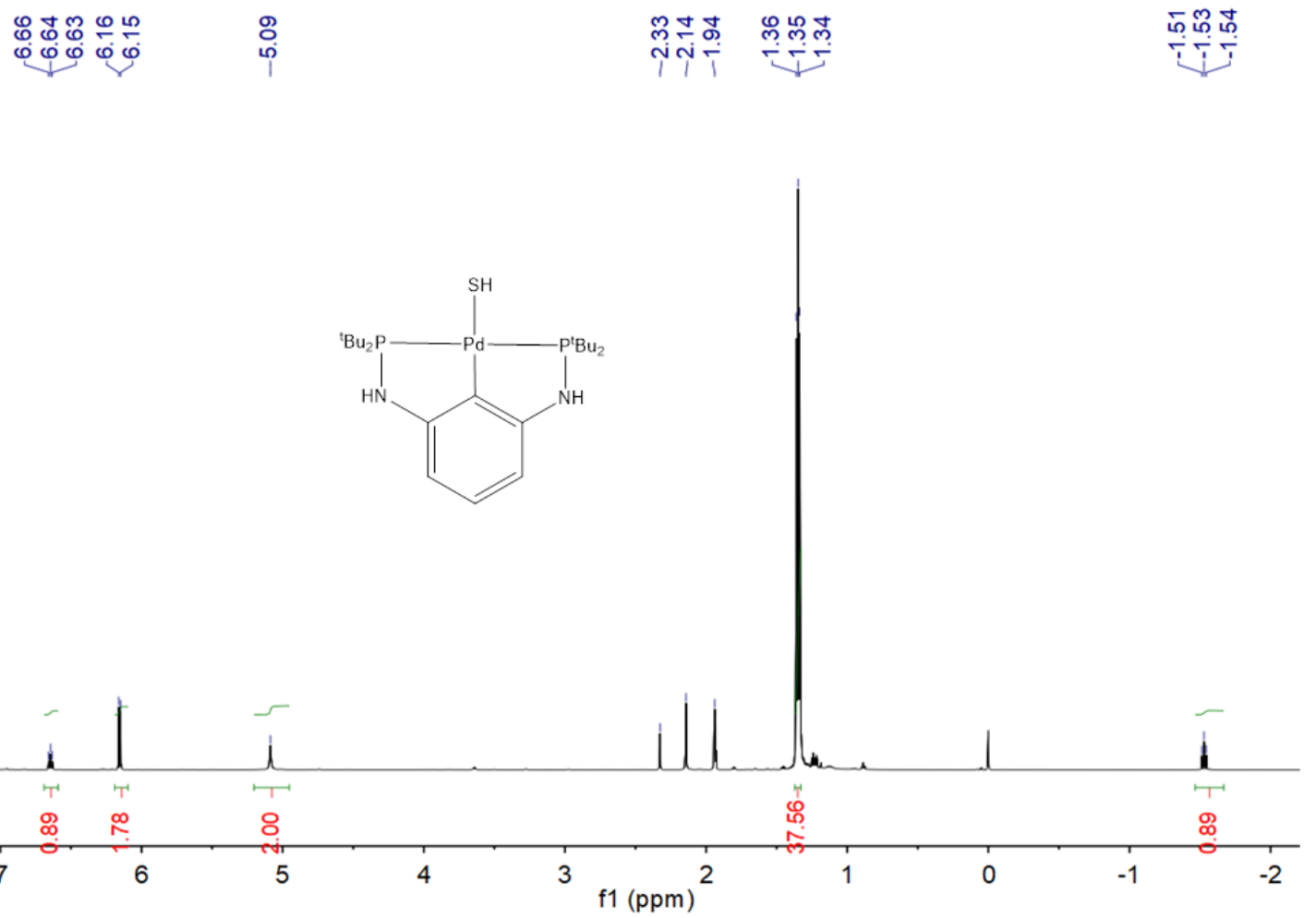

Figure S11. ${ }^{1} \mathrm{H}$ NMR spectrum of complex $4\left(600 \mathrm{MHz}, \mathrm{CD}_{3} \mathrm{CN}\right)$

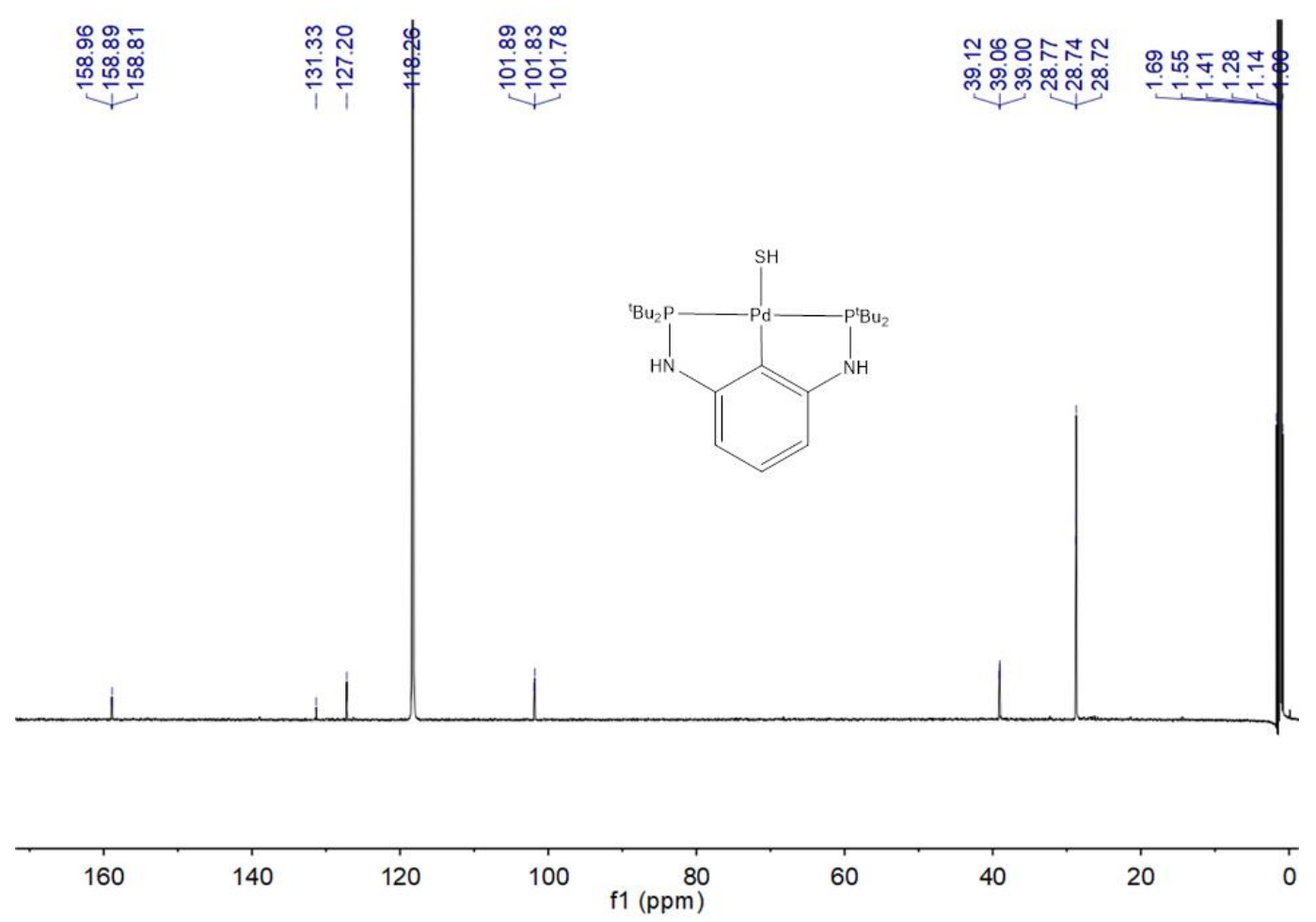

Figure S12. ${ }^{13} \mathrm{C}\left\{{ }^{1} \mathrm{H}\right\}$ NMR spectrum of complex $4\left(151 \mathrm{MHz}, \mathrm{CD}_{3} \mathrm{CN}\right)$ 


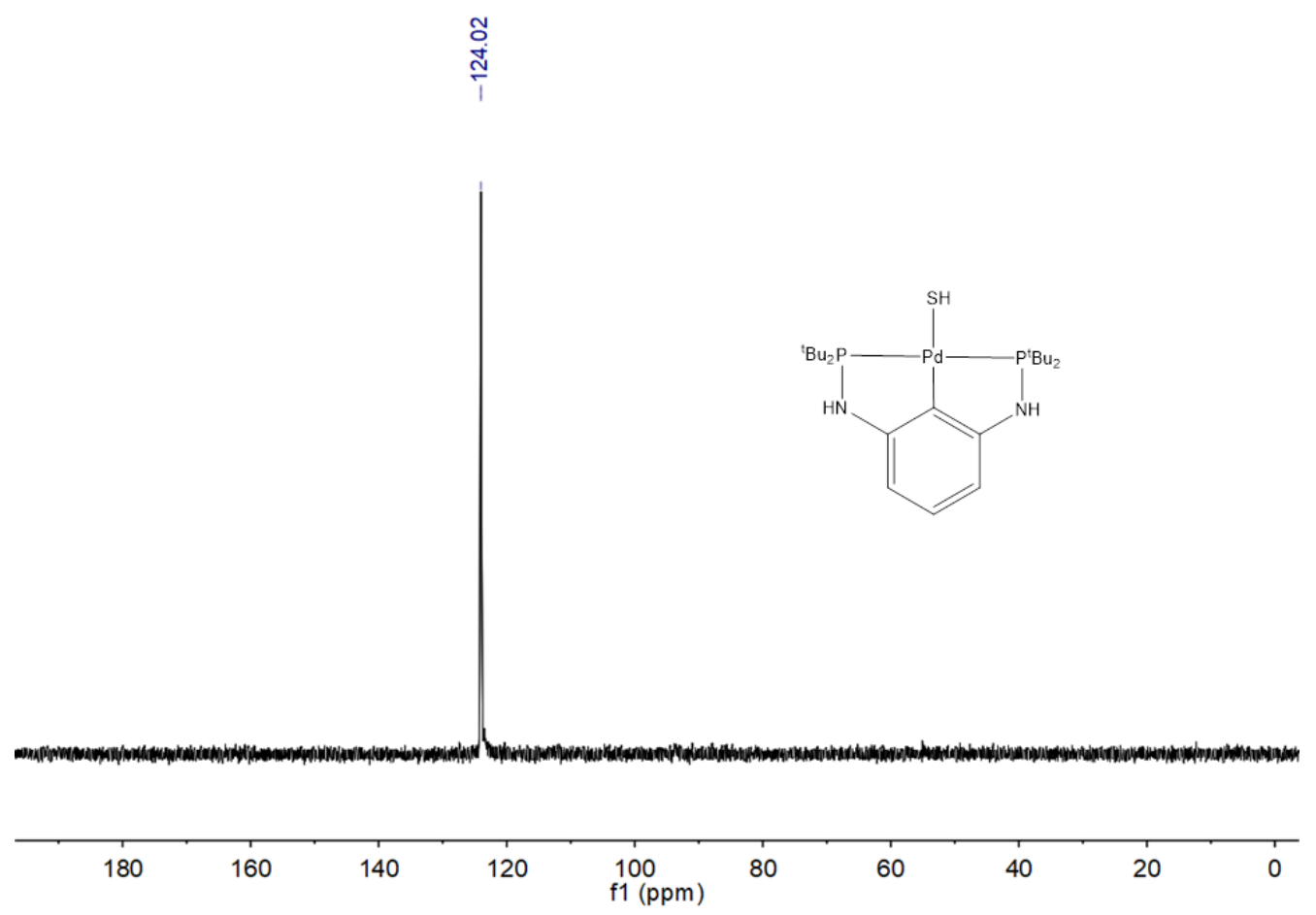

Figure S13. ${ }^{31} \mathrm{P}\left\{{ }^{1} \mathrm{H}\right\}$ NMR spectrum of complex $4\left(243 \mathrm{MHz}, \mathrm{CD}_{3} \mathrm{CN}\right)$

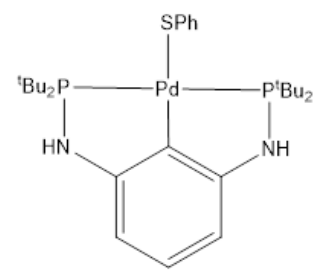

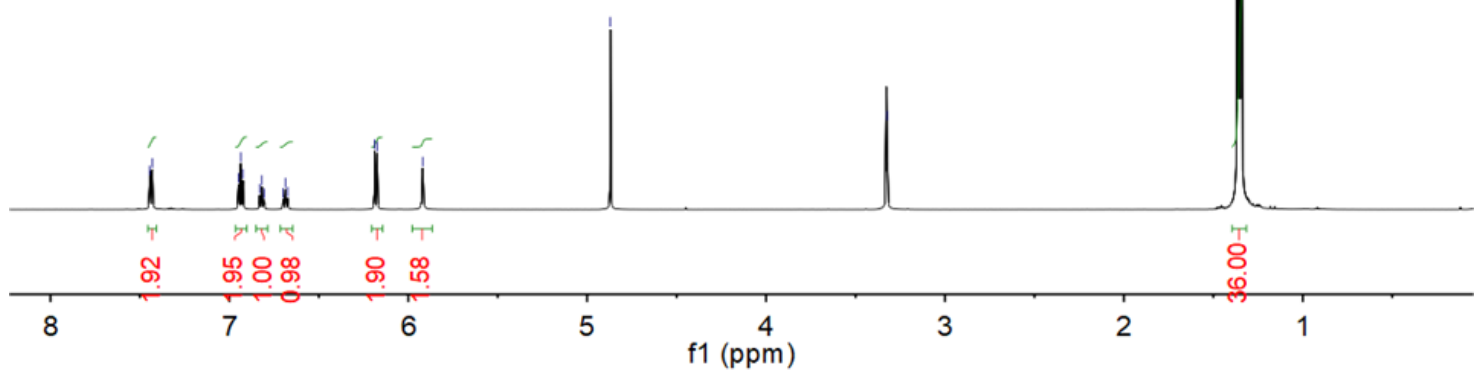

Figure S14. ${ }^{1} \mathrm{H}$ NMR spectrum of complex $5\left(600 \mathrm{MHz}\right.$, methanol- $\left.d_{4}\right)$ 


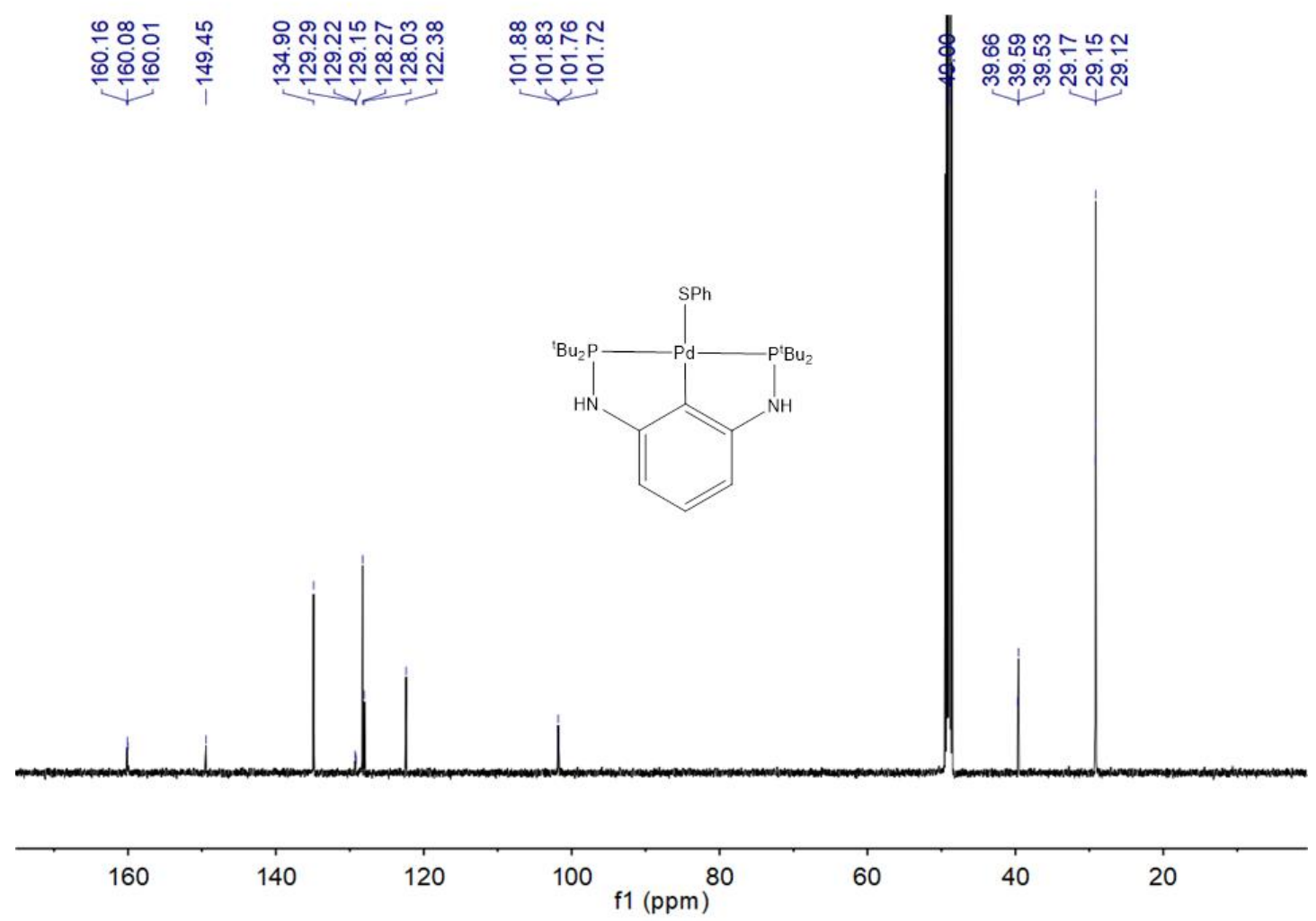

Figure S15. ${ }^{13} \mathrm{C}\left\{{ }^{1} \mathrm{H}\right\}$ NMR spectrum of complex $5\left(151 \mathrm{MHz}\right.$, methanol- $\left.d_{4}\right)$

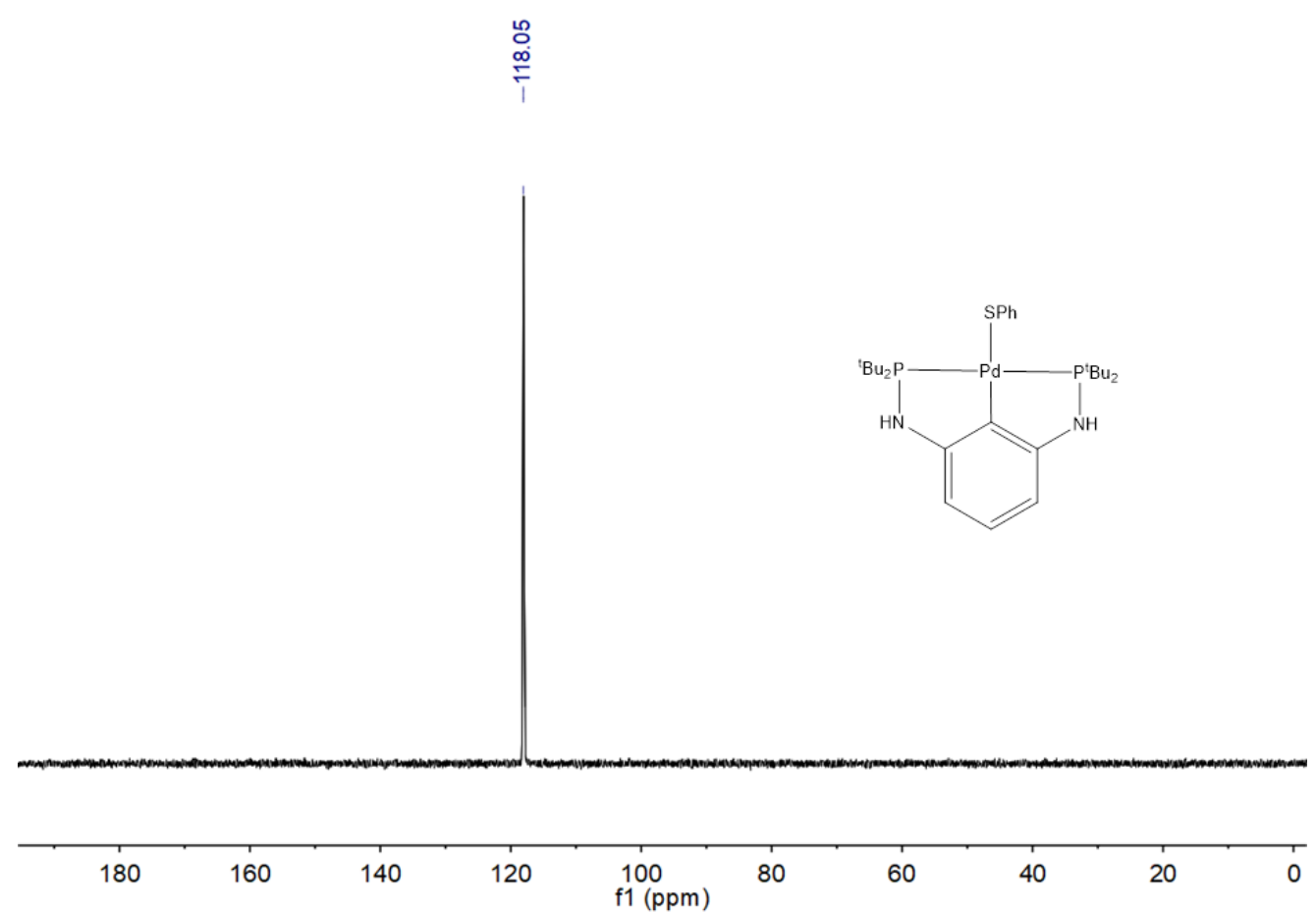

Figure S16. ${ }^{31} \mathrm{P}\left\{{ }^{1} \mathrm{H}\right\}$ NMR spectrum of complex $5\left(243 \mathrm{MHz}\right.$, methanol- $\left.d_{4}\right)$ 


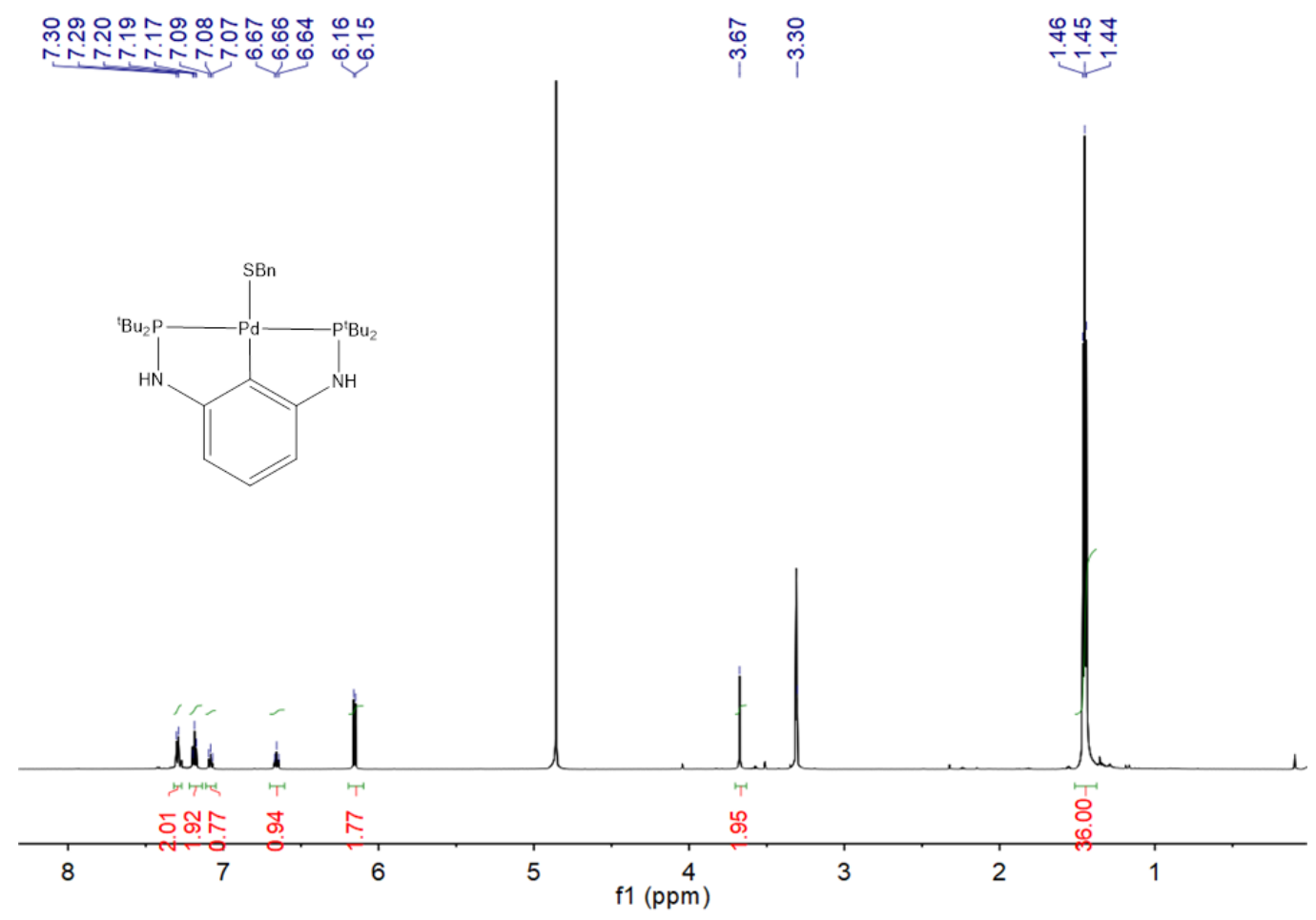

Figure S17. ${ }^{1} \mathrm{H}$ NMR spectrum of complex $6\left(600 \mathrm{MHz}\right.$, methanol- $\left.d_{4}\right)$

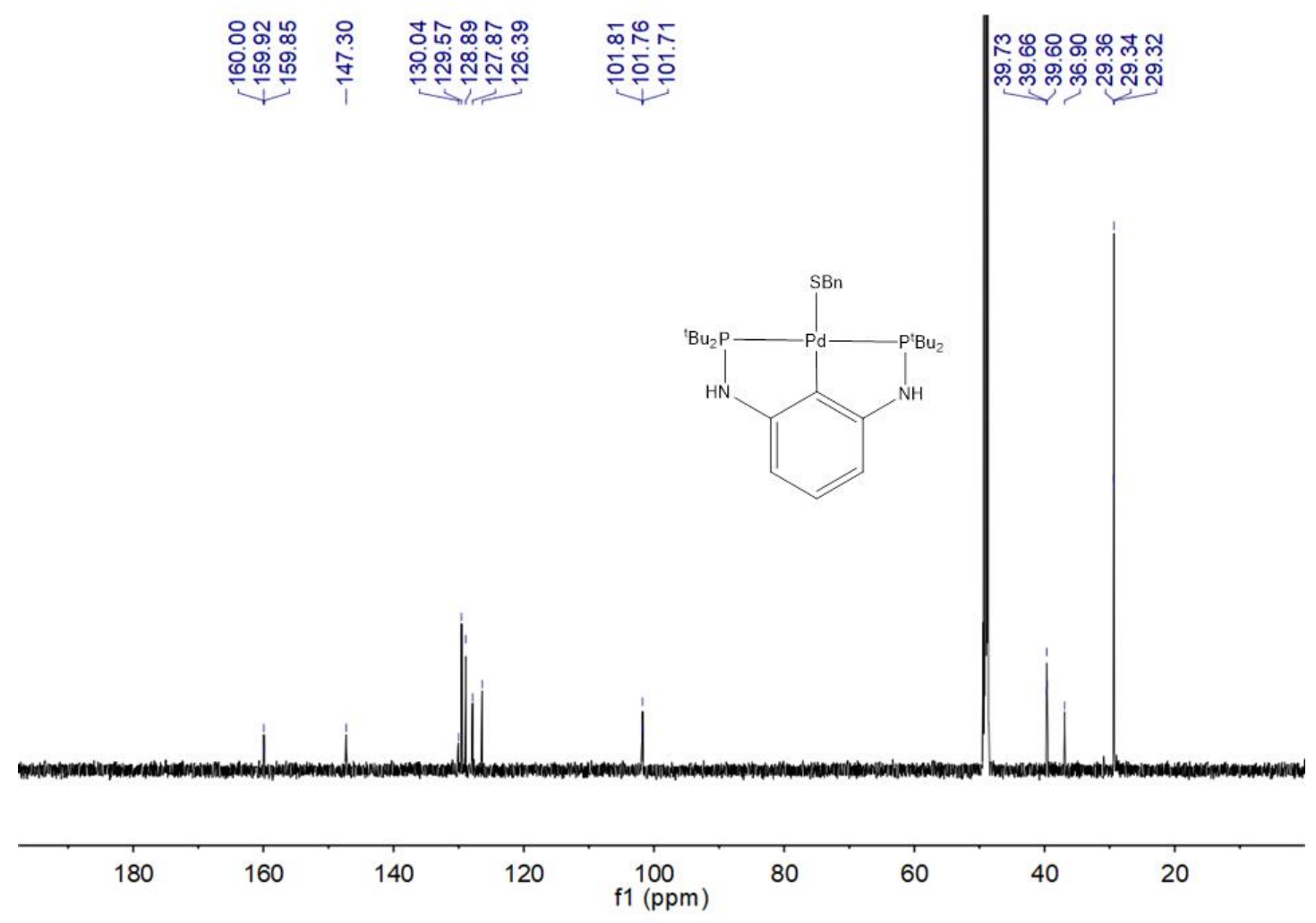

Figure S18. ${ }^{13} \mathrm{C}\left\{{ }^{1} \mathrm{H}\right\}$ NMR spectrum of complex $6\left(151 \mathrm{MHz}\right.$, methanol- $\left.d_{4}\right)$ 


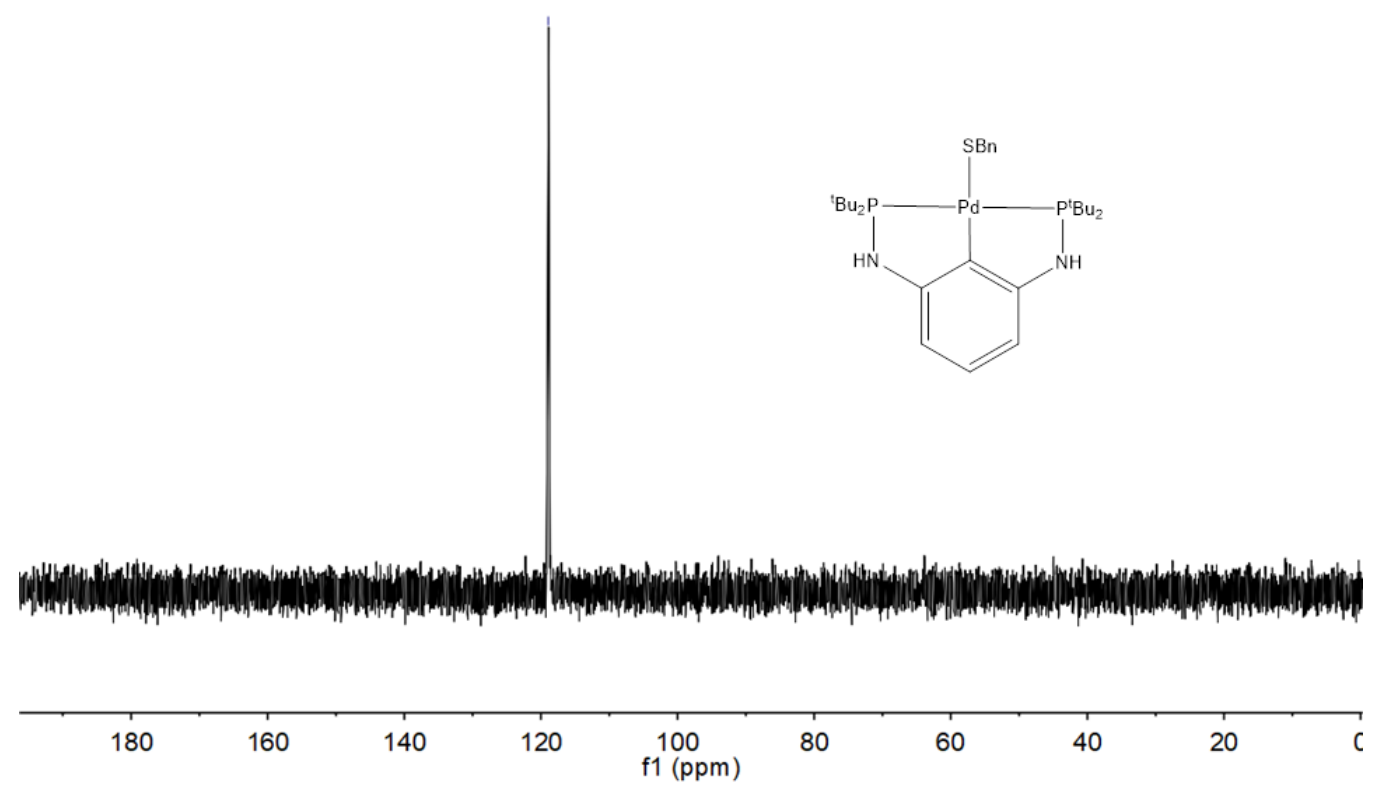

Figure S19. ${ }^{31} \mathrm{P}\left\{{ }^{1} \mathrm{H}\right\}$ NMR spectrum of complex 6 (243 MHz, methanol- $\left.d_{4}\right)$

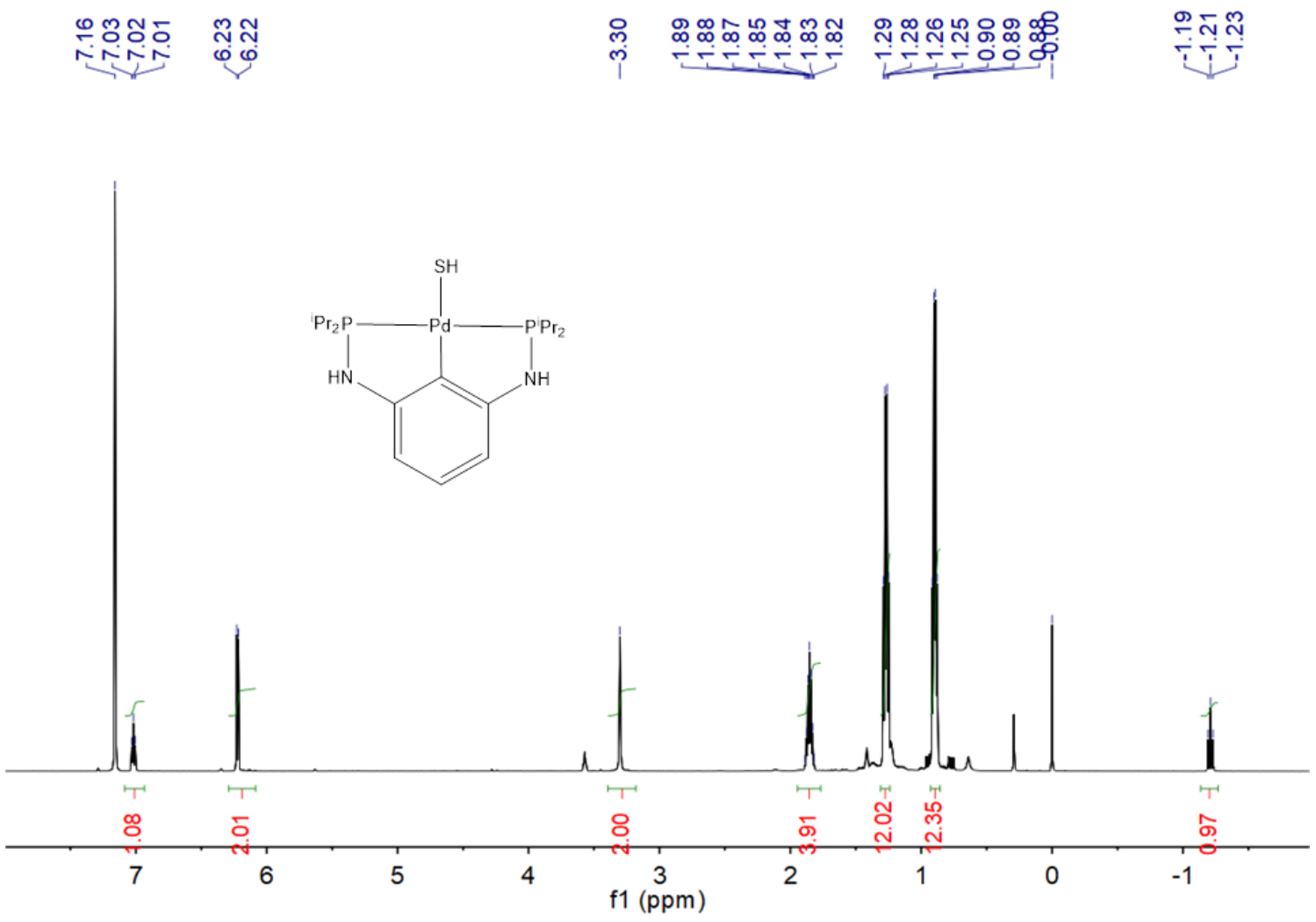

Figure S20. ${ }^{1} \mathrm{H}$ NMR spectrum of complex $7\left(600 \mathrm{MHz}, \mathrm{C}_{6} \mathrm{D}_{6}\right)$ 


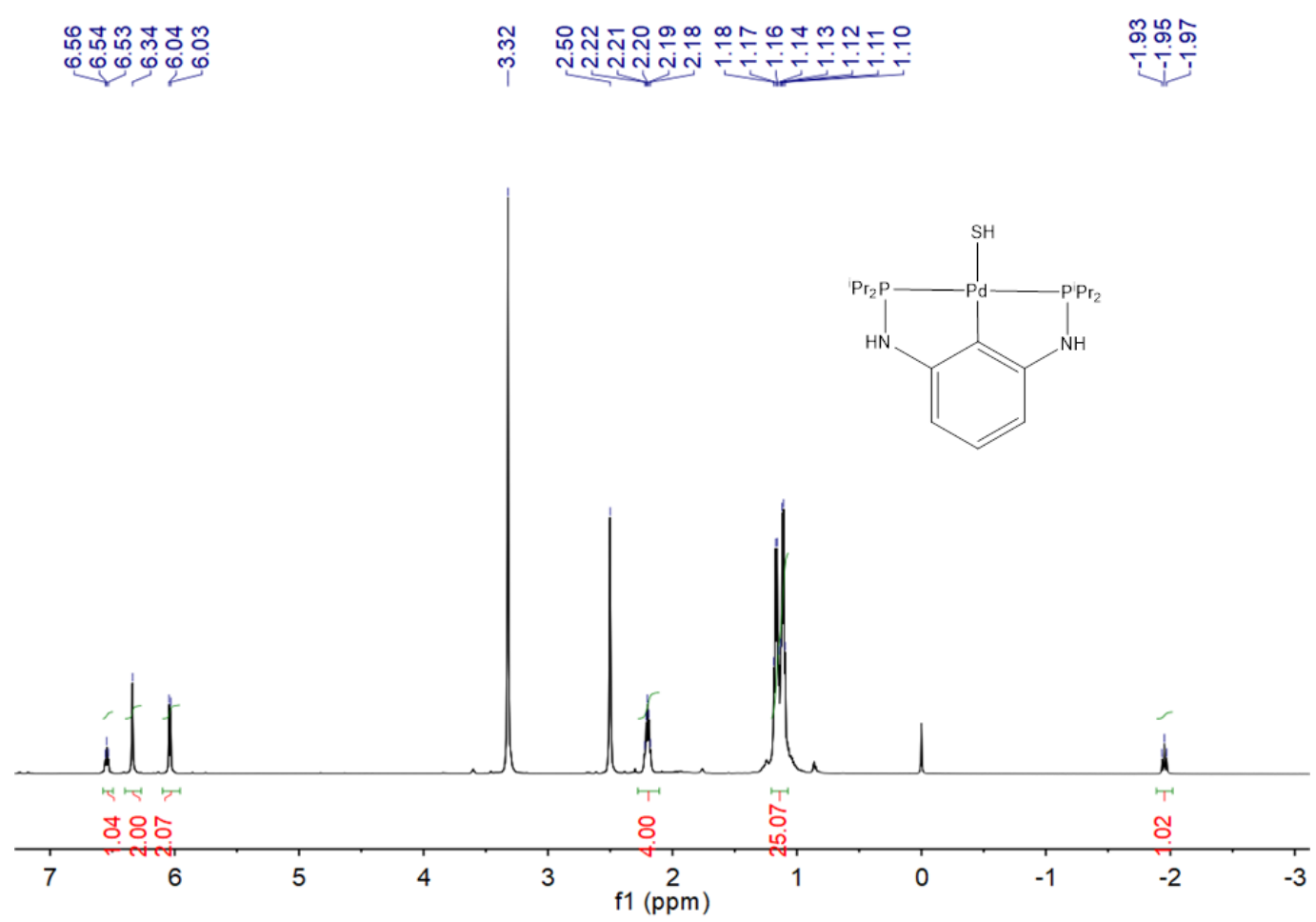

Figure S21. ${ }^{1} \mathrm{H}$ NMR spectrum of complex $7\left(600 \mathrm{MHz}\right.$, DMSO- $\left.d_{6}\right)$

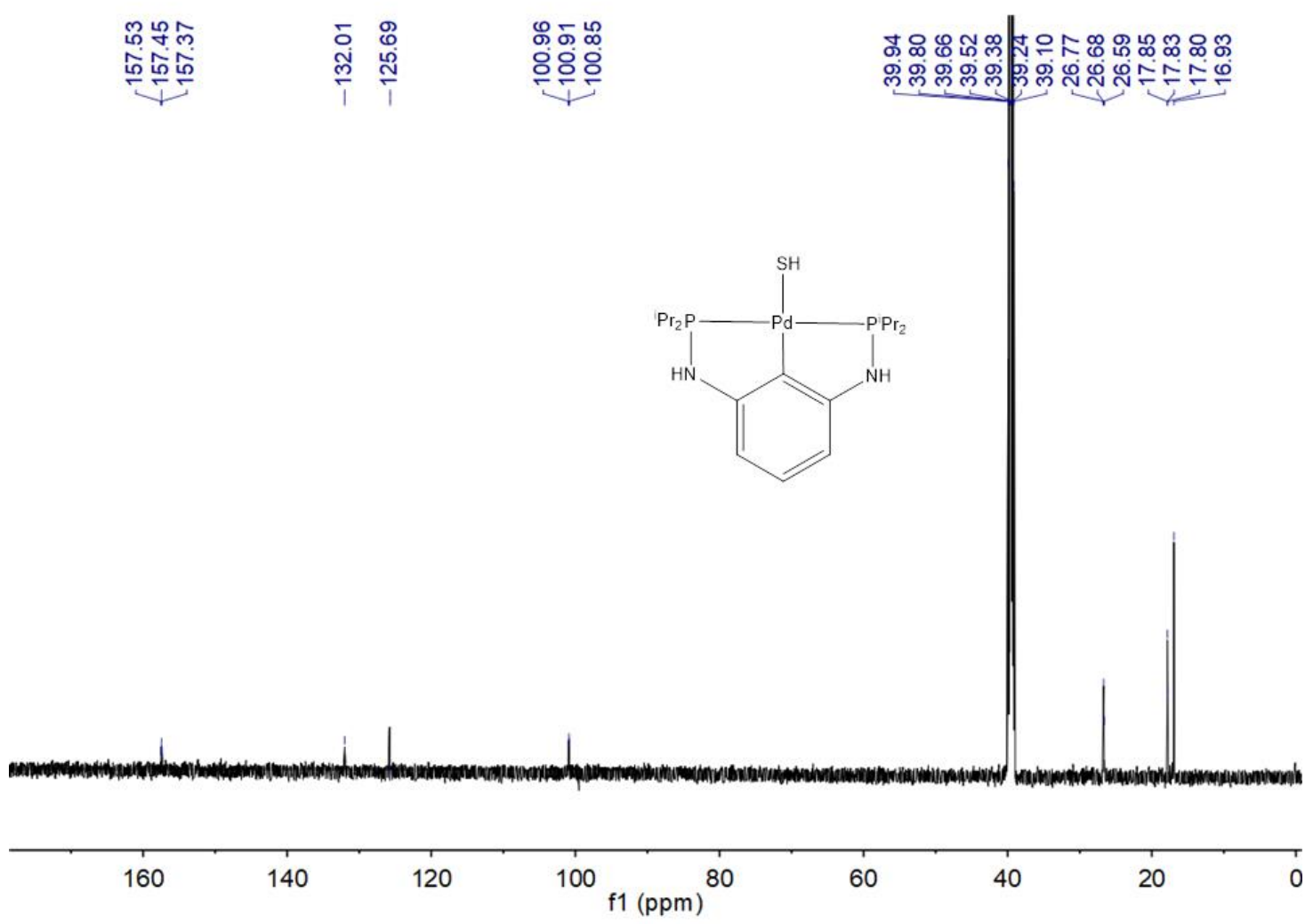

Figure S22. ${ }^{13} \mathrm{C}\left\{{ }^{1} \mathrm{H}\right\}$ NMR spectrum of complex $7\left(151 \mathrm{MHz}\right.$, DMSO- $\left.d_{6}\right)$ 


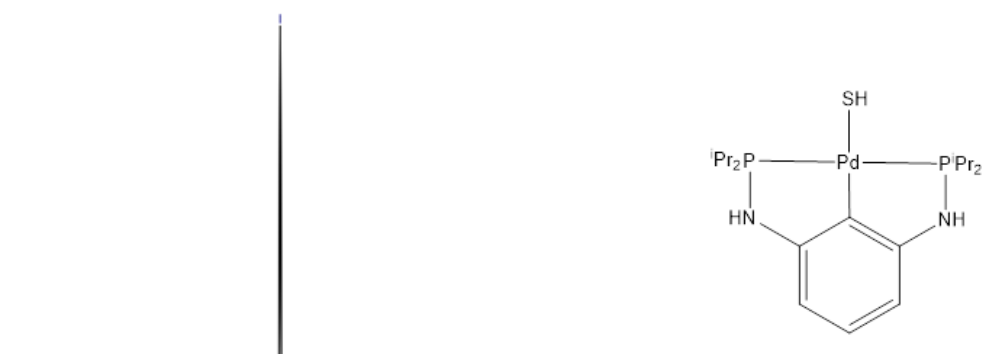

\begin{tabular}{|c|c|c|c|c|c|}
\hline 140 & 120 & 100 & 80 & 6 & 0 \\
\hline
\end{tabular}

Figure S23. ${ }^{31} \mathrm{P}\left\{{ }^{1} \mathrm{H}\right\}$ NMR spectrum of complex $7\left(243 \mathrm{MHz}, \mathrm{C}_{6} \mathrm{D}_{6}\right)$

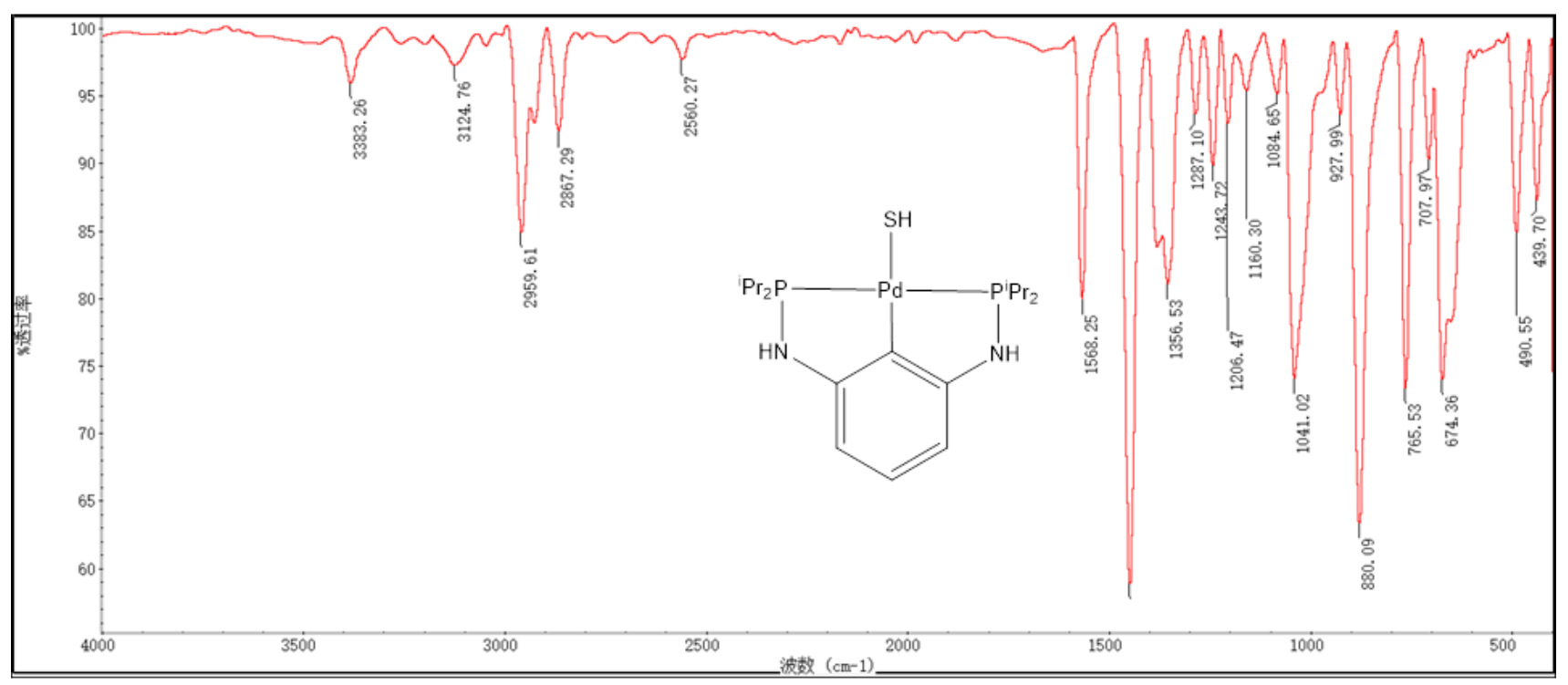

Figure S24. FTIR spectrum of complex 7 (KBr disc) 


\section{X-Ray Structure Determination}

The single crystal X-ray diffraction experiments were carried out on a SuperNova diffractrometer (Oxford Diffraction). The intensity data were collected at 150-298 K using monochromated $\mathrm{Cu}-\mathrm{K} \alpha$ radiation $(\lambda=1.54184 \AA)$. The frames were integrated with the Bruker APEX2 software package using a narrow-frame algorithm. The data were corrected for decay, Lorentz, and polarization effects as well as absorption and beam corrections based on the multi-scan technique. The structures were solved by a combination of direct methods in SHELXTL and the difference Fourier techniques and refined by full-matrix least-squares procedures interfaced with the program $\mathrm{OLEX}_{2} .{ }^{\mathrm{S} 2}$ Non-hydrogen atoms were refined with anisotropic displacement parameters. The $\mathrm{H}$-atoms were either located or calculated and subsequently treated with a riding model. Crystals suitable for X-ray diffraction analysis were obtained at room temperature in $\mathrm{THF} /$ cyclohexane solution for complex $\mathbf{7}$ and toluene/cyclohexane solutions for other complexes. Complex 4 co-crystallized with a toluene molecule; complex 7 co-crystallized with a THF molecule; complex 5 co-crystallized with a toluene molecule and an unidentified solvent molecule which is not included in the structure. Complex $\mathbf{5}$ crystallized as three independent molecules in the lattice. The molecular structures of complexes 1-7 are shown in Figures S26-S32 along with selected bond lengths and angles. Summaries of the crystallographic data and structure refinement for these complexes are presented in Tables $\mathrm{S} 1$ and $\mathrm{S} 2$.

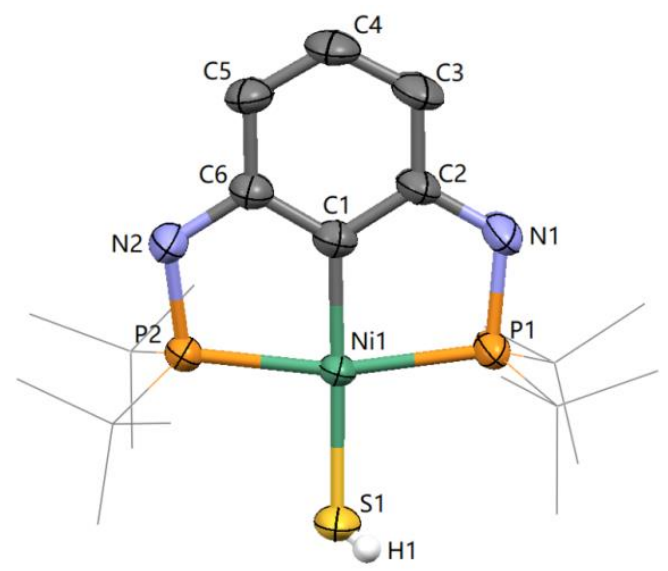

Figure S25. Thermal ellipsoid plots of complex 1 at the 50\% probability level (for clarity, hydrogen atoms except that attached to the $\mathrm{S}$ atom have been omitted and the tert-butyl groups have been simplified). Selected bond lengths $(\AA)$ and angles $\left({ }^{\circ}\right)$ : Ni1-C1, 1.918(4); Ni1-P1, 2.2016(11); Ni1-P2, 2.1926(10); Ni1-S1, 2.2199(13); P1-Ni1-P2, 166.48(5); C1-Ni1-S1, 177.82(14); P1-Ni1-S1, 97.47(5); P2-Ni1-S1, 95.80(5); P1-Ni1-C1, 83.75(13); P2-Ni1-C1, 83.07(13). 


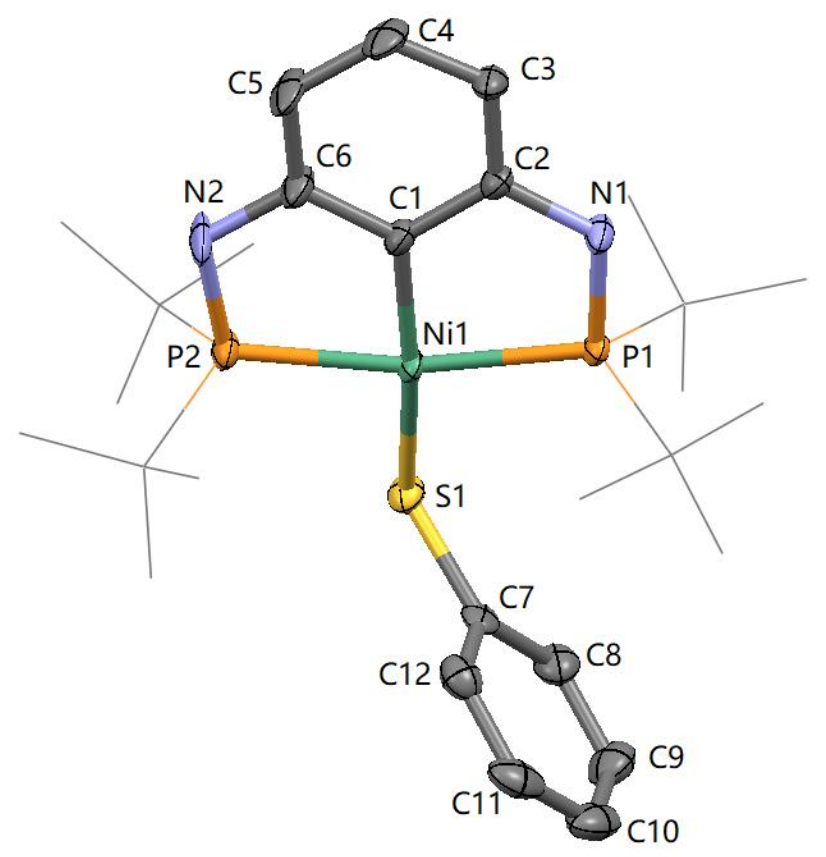

Figure S26. Thermal ellipsoid plots of complex 2 at the 50\% probability level (for clarity, hydrogen atoms have been omitted and the tert-butyl groups have been simplified). Selected bond lengths $(\AA)$ and angles $\left({ }^{\circ}\right)$ : Ni1-C1, 1.913(6); Ni1-P1, 2.2402(18); Ni1-P2, 2.2019(18); Ni1-S1, 2.2427(18); P1-Ni1-P2, 166.93(7); C1-Ni1-S1, 168.51(19); P1-Ni1-S1, 102.40(6); P2-Ni1-S1, 90.59(7); P1-Ni1-C1, 83.6(2); P2-Ni1-C1, 83.4(2).

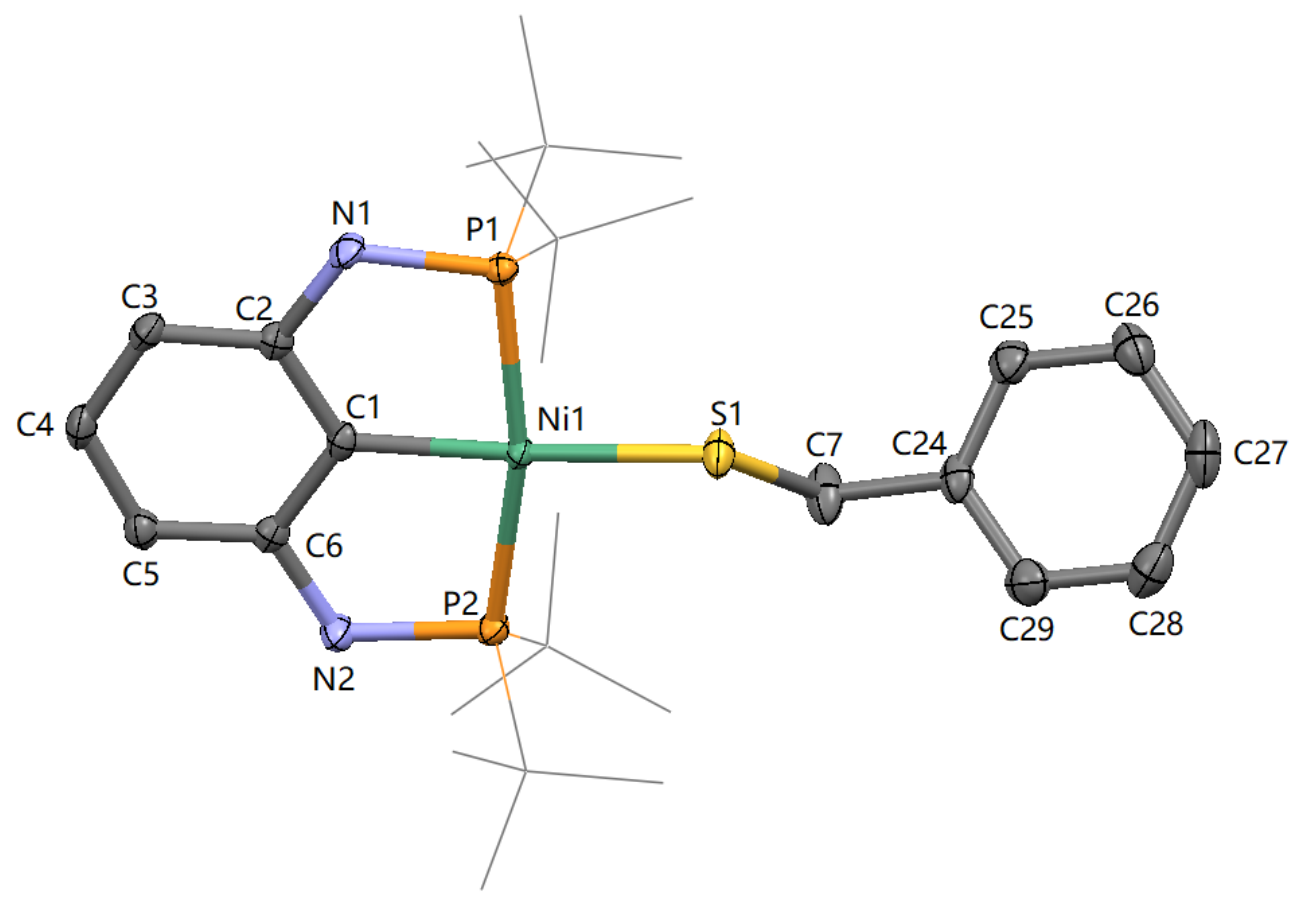

Figure S27. Thermal ellipsoid plots of complex 3 at the 50\% probability level (for clarity, hydrogen atoms have been omitted and the tert-butyl groups have been simplified). Selected bond lengths $(\AA)$ and angles $\left({ }^{\circ}\right)$ : Ni1-C1, 1.9254(15); Ni1-P1, 2.1781(4); Ni1-P2, 2.2188(5); Ni1-S1, 2.2337(5); P1-Ni1-P2, 166.179(19); C1-Ni1-S1, 167.85(5); P1-Ni1-S1, 89.150(17); P2-Ni1-S1, 104.431(18); P1-Ni1-C1, 83.09(5); P2-Ni1-C1, 83.90(5). 


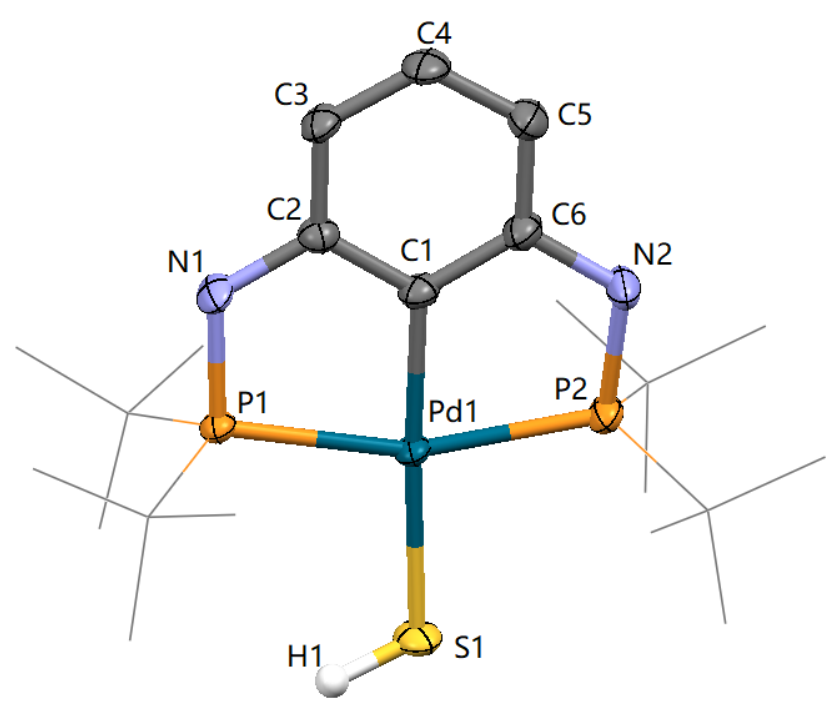

Figure S28. Thermal ellipsoid plots of complex 4 at the 50\% probability level (for clarity, hydrogen atoms except that attached to the $\mathrm{S}$ atom and a solvent molecule have been omitted and the tert-butyl groups have been simplified). Selected bond lengths $(\AA)$ and angles ( ${ }^{\circ}$ ): Pd1-C1, 2.025(3); Pd1-P1, 2.3247(8); Pd1-P2, 2.2980(9); Pd1-S1, 2.3837(8); P1-Pd1-P2, 162.47(3); C1-Pd1-S1, 176.65(10); P1-Pd1-S1, 101.53(3); P2-Pd1-S1, 95.55(3); P1-Pd1-C1, 81.79(11); P2-Ni1-C1, 81.17(11).

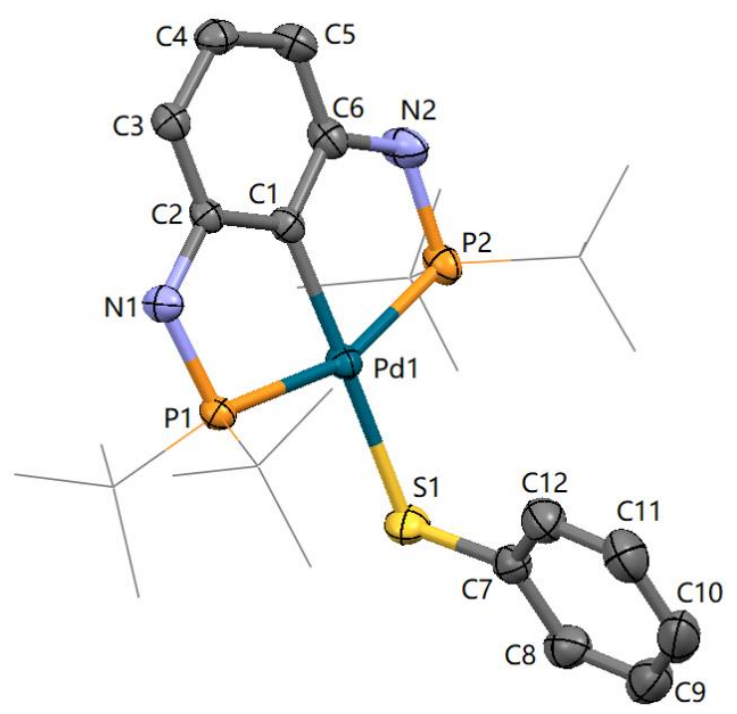

Figure S29. Thermal ellipsoid plots of complex $\mathbf{5}$ at the 50\% probability level (three independent molecules were found in the lattice, only one is shown here; for clarity, hydrogen atoms and a solvent molecule have been omitted and the tert-butyl groups have been simplified). Selected bond lengths ( $\AA$ ) and angles ( ${ }^{\circ}$ ): Pd1-C1, 2.033(4); Pd1-P1, 2.3259(11); Pd1-P2, 2.3196(12); Pd1-S1, 2.4382(12); P1-Pd1-P2, 161.98(4); C1-Pd1-S1, 176.33(12); P1-Pd1-S1, 99.52(4); P2-Pd1-S1, 97.84(5); P1-Pd1-C1, 81.56(12); P2-Ni1-C1, 80.82(13). 


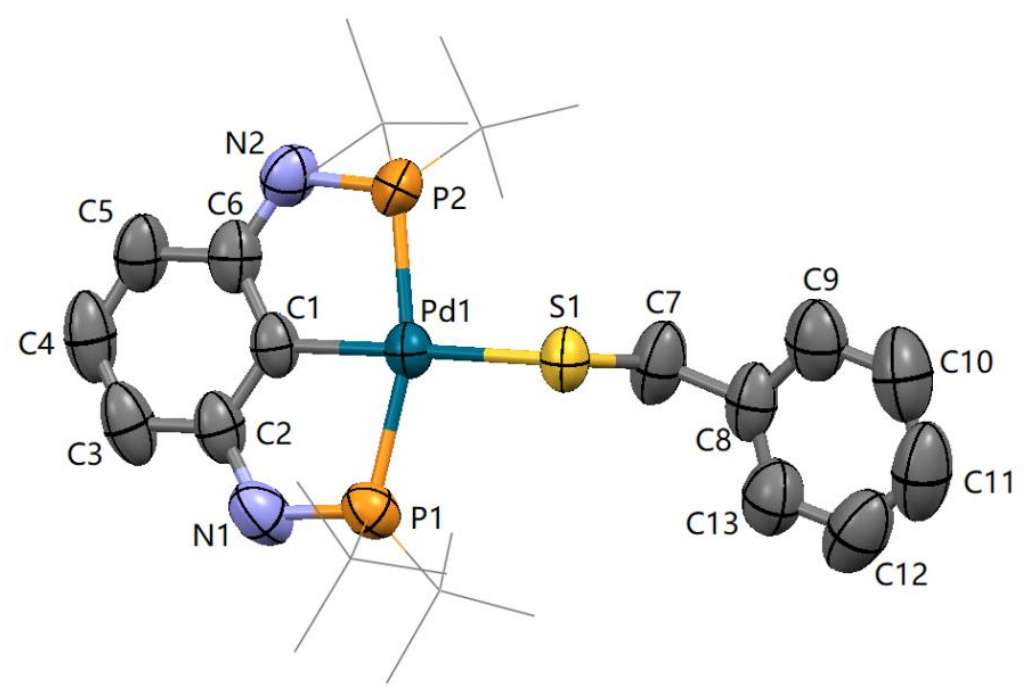

Figure S30. Thermal ellipsoid plots of complex 6 at the 50\% probability level (or clarity, hydrogen atoms have been omitted and the tert-butyl groups have been simplified). Selected bond lengths $(\AA)$ and angles $\left({ }^{\circ}\right)$ : Pd1-C1, 2.029(6); Pd1-P1, 2.304(2); Pd1-P2, 2.297(2); Pd1-S1, 2.4350(16); P1-Pd1-P2, 162.21(7); C1-Pd1-S1, 176.51(18); P1-Pd1-S1, 97.46(7); P2-Pd1-S1, 99.95(7); P1-Pd1-C1, 81.1(2); P2-Ni1-C1, 81.3(2).

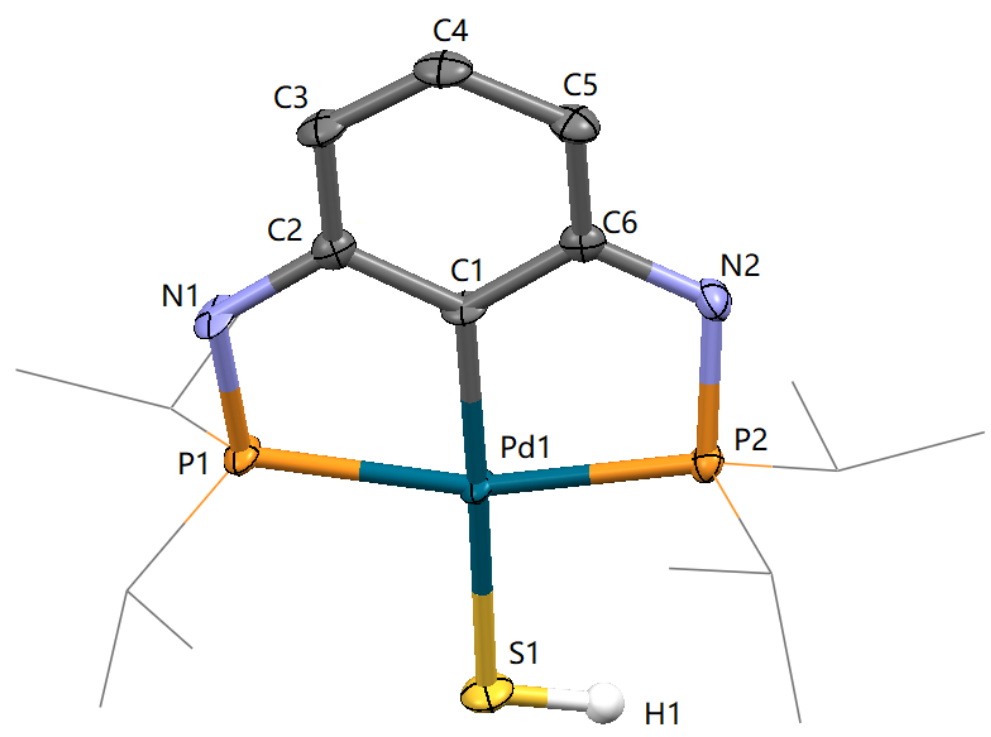

Figure S31. Thermal ellipsoid plots of complex 7 at the 50\% probability level (for clarity, hydrogen atoms except that attached to the $\mathrm{S}$ atom and a solvent molecule have been omitted and the isopropyl groups have been simplified). Selected bond lengths $(\AA)$ and angles ( ${ }^{\circ}$ ): Pd1-C1, 2.023(4); Pd1-P1, 2.2793(9); Pd1-P2, 2.2756(9); Pd1-S1, 2.3818(10); P1-Pd1-P2, 162.35(3); C1-Pd1-S1, 177.71(10); P1-Pd1-S1, 96.64(3); P2-Pd1-S1, 100.91(3); P1-Pd1-C1, 81.68(11); P2-Ni1-C1, 80.82(11). 
Table S1. Summary of crystal data and structure refinement for complexes 1-4

\begin{tabular}{lllll}
\hline Complex & $(\mathbf{1})$ & $(\mathbf{2})$ & $(\mathbf{3})$ & $(\mathbf{4}) \cdot \mathrm{C}_{7} \mathrm{H}_{8}$ \\
\hline CCDC number & 2090769 & 2090770 & 2090771 & 2090772 \\
Empirical formula & $\mathrm{C}_{22} \mathrm{H}_{42} \mathrm{~N}_{2} \mathrm{NiP}_{2} \mathrm{~S}$ & $\mathrm{C}_{28} \mathrm{H}_{46} \mathrm{~N}_{2} \mathrm{NiP}_{2} \mathrm{~S}$ & $\mathrm{C}_{29} \mathrm{H}_{48} \mathrm{~N}_{2} \mathrm{NiP}_{2} \mathrm{~S}$ & $\mathrm{C}_{29} \mathrm{H}_{50} \mathrm{~N}_{2} \mathrm{P}_{2} \mathrm{PdS}$ \\
Formula weight & 487.28 & 563.38 & 577.40 & 627.11 \\
Temp, K & 298 & 150 & 150 & 170 \\
Crystal system & orthorhombic & orthorhombic & orthorhombic & monoclinic \\
Space group & $\mathrm{Pna}_{1}$ & $\mathrm{Pna}_{1}$ & $\mathrm{Pbca}$ & $\mathrm{P}{ }_{1} / \mathrm{n}$ \\
$a, \AA$ & $22.6731(3)$ & $21.4745(3)$ & $10.7340(2)$ & $8.16290(10)$ \\
$b, \AA$ & $8.17890(10)$ & $8.78920(10)$ & $15.6737(2)$ & $28.7891(4)$ \\
$c, \AA$ & $13.9487(2)$ & $15.6698(2)$ & $35.8531(4)$ & $13.4127(2)$ \\
$\alpha\left(^{\circ}\right)$ & 90 & 90 & 90 & 90 \\
$\beta\left(^{\circ}\right)$ & 90 & 90 & 90 & $97.8290(10)$ \\
$\gamma\left(^{\circ}\right)$ & 90 & 90 & 90 & 90 \\
Volume, $\AA^{3}$ & $2586.66(6)$ & $2957.58(7)$ & $6031.98(15)$ & $3122.64(7)$ \\
$\mathrm{Z}$ & 4 & 4 & 8 & 4 \\
$d_{\text {calc }}$, g cm & -3 & 1.265 & 1.272 & 1.334 \\
$\lambda, \AA$ & 1.251 & 1.54184 & 1.54184 & 1.54184 \\
$\mu$, mm & -1 & 2.757 & 2.715 & 6.522 \\
No. of data collected & 7778 & 14354 & 23366 & 17089 \\
No. of unique data & 3411 & 5044 & 5773 & 5965 \\
$R_{\text {int }}$ & 0.0437 & 0.0819 & 0.0289 & 0.0600 \\
Goodness-of-fit on $F^{2}$ & 1.072 & 1.081 & 1.000 & 1.049 \\
$R_{1}$, w $R_{2}(I>2 \sigma(I))$ & $0.0398,0.1004$ & $0.0683,0.1690$ & $0.0339,0.1157$ & $0.0464,0.1269$ \\
$R_{1}$, w $R_{2}$ (all data) & $0.0497,0.1033$ & $0.0793,0.1760$ & $0.0371,0.1203$ & $0.0541,0.1346$ \\
\hline & & & & \\
\hline
\end{tabular}


Table S2. Summary of crystal data and structure refinement for complexes 5-7

\begin{tabular}{|c|c|c|c|}
\hline Complex & $3(\mathbf{5}) \cdot \mathrm{C}_{7} \mathrm{H}_{8}$ & $(6)$ & $(7) \cdot \mathrm{C}_{4} \mathrm{H}_{8} \mathrm{O}$ \\
\hline CCDC number & 2090773 & 2090774 & 2090775 \\
\hline Empirical formula & $\mathrm{C}_{91} \mathrm{H}_{146} \mathrm{~N}_{6} \mathrm{P}_{6} \mathrm{Pd}_{3} \mathrm{~S}_{3}$ & $\mathrm{C}_{29} \mathrm{H}_{48} \mathrm{~N}_{2} \mathrm{P}_{2} \mathrm{PdS}$ & $\mathrm{C}_{22} \mathrm{H}_{42} \mathrm{~N}_{2} \mathrm{OP}_{2} \mathrm{PdS}$ \\
\hline Formula weight & 1925.33 & 625.09 & 551.02 \\
\hline Temp, K & 161 & 293 & 150 \\
\hline Crystal system & triclinic & orthorhombic & monoclinic \\
\hline Space group & $\mathrm{P}-1$ & Pbca & $\mathrm{P} 2_{1} / \mathrm{n}$ \\
\hline$a, \AA$ & $11.3685(2)$ & $14.7631(4)$ & $10.37250(10)$ \\
\hline$b, \AA$ & $20.8486(4)$ & $18.7877(6)$ & $22.7578(2)$ \\
\hline$c, \AA$ & $23.6239(4)$ & $23.1611(7)$ & $11.14260(10)$ \\
\hline$\alpha\left(^{\circ}\right)$ & $112.755(2)$ & 90 & 90 \\
\hline$\beta\left(^{\circ}\right)$ & $96.9130(10)$ & 90 & $98.0500(10)$ \\
\hline$\gamma\left({ }^{\circ}\right)$ & $100.2800(10)$ & 90 & 90 \\
\hline Volume, $\AA^{3}$ & $4968.67(17)$ & $6424.1(3)$ & $2604.35(4)$ \\
\hline $\mathrm{Z}$ & 2 & 8 & 4 \\
\hline$d_{\text {calc }}, \mathrm{g} \mathrm{cm}^{-3}$ & 1.287 & 1.293 & 1.4052 \\
\hline$\lambda, \AA$ & 1.54184 & 1.54184 & 1.54184 \\
\hline$\mu, \mathrm{mm}^{-1}$ & 6.163 & 6.340 & 7.770 \\
\hline No. of data collected & 45428 & 17403 & 16650 \\
\hline No. of unique data & 18958 & 6154 & 4995 \\
\hline$R_{\text {int }}$ & 0.0315 & 0.0491 & 0.0600 \\
\hline Goodness-of-fit on $F^{2}$ & 1.024 & 1.034 & 1.036 \\
\hline$R_{1}, \mathrm{w} R_{2}(I>2 \sigma(I))$ & $0.0453,0.1161$ & $0.0594,0.1368$ & $0.0459,0.1265$ \\
\hline$R_{1}, \mathrm{w} R_{2}$ (all data) & $0.0517,0.1202$ & $0.1070,0.1622$ & $0.0482,0.1302$ \\
\hline
\end{tabular}



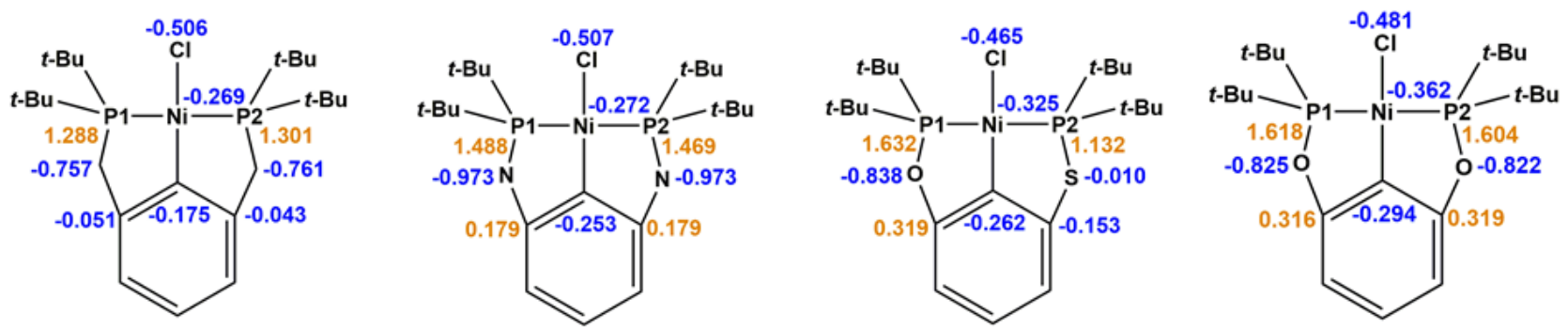

Figure S32. NPA charges of selected atoms in complexes $\left[2,6-\left({ }^{\mathrm{t}} \mathrm{Bu}_{2} \mathrm{PY}\right)_{2} \mathrm{C}_{6} \mathrm{H}_{3}\right] \mathrm{NiCl}\left(\mathrm{Y}=\mathrm{CH}_{2}, \mathrm{NH}, \mathrm{S} / \mathrm{O}, \mathrm{O}\right)$.
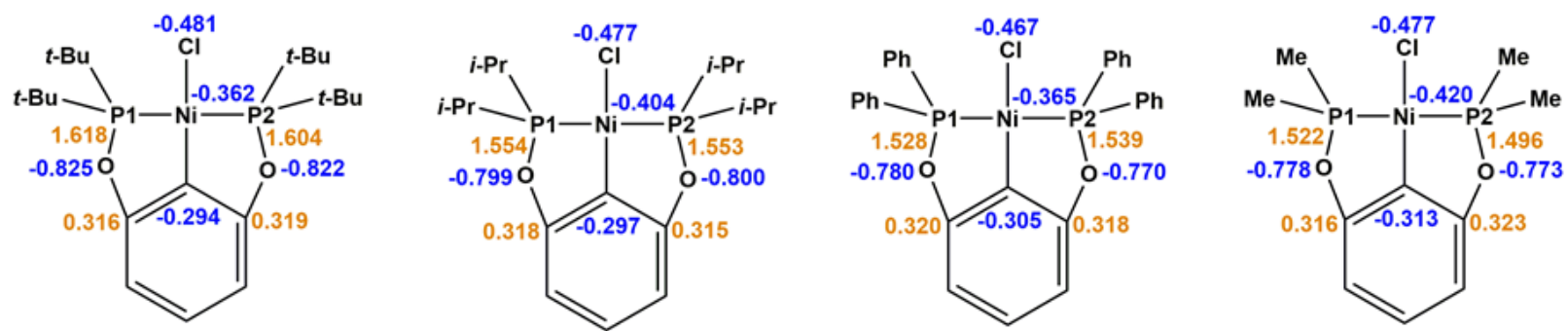

Figure S33. NPA charges of selected atoms in complexes $\left[2,6-\left(\mathrm{R}_{2} \mathrm{PO}\right)_{2} \mathrm{C}_{6} \mathrm{H}_{3}\right] \mathrm{NiCl}\left(\mathrm{R}={ }^{t} \mathrm{Bu},{ }^{\mathrm{i}} \mathrm{Pr}, \mathrm{Ph}, \mathrm{Me}\right)$.
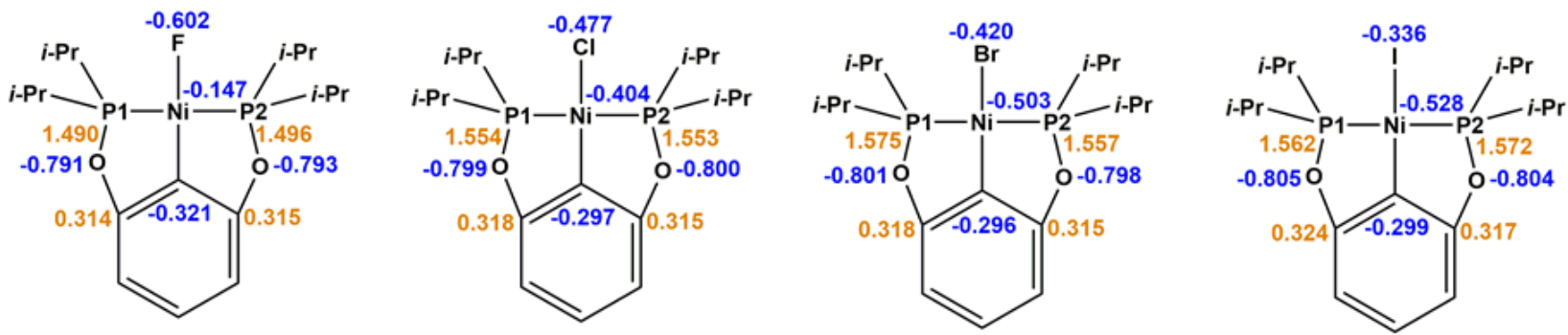

Figure S34. NPA charges of selected atoms in complexes $\left[2,6-\left({ }^{\mathrm{i}} \mathrm{Pr}_{2} \mathrm{PO}\right)_{2} \mathrm{C}_{6} \mathrm{H}_{3}\right] \mathrm{NiX}(\mathrm{X}=\mathrm{F}, \mathrm{Cl}, \mathrm{Br}, \mathrm{I})$.

\section{Computational Methods}

The computations were based on the molecular structures obtained through X-ray crystallography experiments ${ }^{\mathrm{S} 3}$ and performed by using Gaussian 09 software. ${ }^{\mathrm{S} 4}$ The PBE0 functional was used for geometry optimization, vibrational frequencies and natural population analysis (NPA). The TPSSh functional was used for single-point calculation. The DFT-D3 dispersion correction was applied in the optimization and single-point calculation. ${ }^{\mathrm{S} 5}$ The geometry optimization, vibrational frequency and NPA were calculated using the 6-311G(d,p) basis set for $\mathrm{H}, \mathrm{C}, \mathrm{N}, \mathrm{O}, \mathrm{F}, \mathrm{P}$ and $\mathrm{Cl}$, and the def2-TZVP basis set for Br, I, Ni. The single-point calculation was using the $6-311+\mathrm{G}(2 \mathrm{df}, 2 \mathrm{p})$ basis set for H, C, N, O, F, P and Cl, and the def2-TZVPD basis set for Br, I, and Ni. The def2-TZVP and def2-TZVPD basis sets were obtained from the Basis Set Exchange. ${ }^{\text {S6 }}$ It should be noticed that the def2-TZVP and def2-TZVPD basis sets are all-electron basis set for elements in the first four periods of the periodic table. For the other elements, they are pseudopotential basis sets. The 
frequencies calculations verified that all the structures are desired local minima. The topology analysis of atoms in molecules (AIM) methodology and Mayer bond order were analyzed using the Multiwfn software package to get the bond critical point (BCP) properties (density of electron and density of potential energy) and the bond order. ${ }^{\text {S7 }}$

Table S3. Electron Density $\left(\rho, \mathrm{e} \mathrm{Bohr}^{3}\right)$ and Potential Energy Density $\left(\mathrm{V}\right.$, Hartree/Bohr $\left.{ }^{3}\right)$ at Bond Critical Point for Complexes [2,6-( $\left.\left.{ }^{\mathrm{t}} \mathrm{Bu}_{2} \mathrm{PY}\right)_{2} \mathrm{C}_{6} \mathrm{H}_{3}\right] \mathrm{NiCl}\left(\mathrm{Y}=\mathrm{CH}_{2}, \mathrm{NH}, \mathrm{S} / \mathrm{O}, \mathrm{O}\right)$

\begin{tabular}{|c|c|c|c|c|c|c|c|c|c|c|c|c|}
\hline & \multicolumn{3}{|l|}{$\mathrm{Y}=\mathrm{CH}_{2}$} & \multicolumn{3}{|l|}{$\mathrm{Y}=\mathrm{NH}$} & \multicolumn{3}{|c|}{$\mathrm{Y}=\mathrm{S} / \mathrm{O}$} & \multicolumn{3}{|l|}{$\mathrm{Y}=\mathrm{O}$} \\
\hline & $\mathrm{Ni}-\mathrm{C}_{i p s o}$ & Ni-P & $\mathrm{Ni}-\mathrm{Cl}$ & $\mathrm{Ni}-\mathrm{C}_{i p s o}$ & Ni-P & $\mathrm{Ni}-\mathrm{Cl}$ & $\mathrm{Ni}-\mathrm{C}_{i p s o}$ & Ni-P & $\mathrm{Ni}-\mathrm{Cl}$ & $\mathrm{Ni}-\mathrm{C}_{i p s o}$ & Ni-P & $\mathrm{Ni}-\mathrm{Cl}$ \\
\hline$\rho$ & 0.123 & 0.096 & 0.073 & 0.125 & 0.094 & 0.073 & 0.127 & $0.092 / 0.102$ & 0.078 & 0.130 & 0.098 & 0.078 \\
\hline V & -0.156 & -0.112 & -0.100 & -0.159 & -0.110 & -0.100 & -0.167 & $-0.109 /-0.121$ & -0.108 & -0.173 & -0.116 & -0.108 \\
\hline
\end{tabular}

Table S4. Electron Density $\left(\rho, \mathrm{e} /\right.$ Bohr $\left.^{3}\right)$ and Potential Energy Density (V, Hartree/Bohr $\left.{ }^{3}\right)$ at Bond Critical Point for Complexes [2,6-( $\left.\left(\mathrm{R}_{2} \mathrm{PO}\right)_{2} \mathrm{C}_{6} \mathrm{H}_{3}\right] \mathrm{NiCl}\left(\mathrm{R}={ }^{\mathrm{t}} \mathrm{Bu},{ }^{\mathrm{i}} \mathrm{Pr}, \mathrm{Ph}, \mathrm{Me}\right)$

\begin{tabular}{|c|c|c|c|c|c|c|c|c|c|c|c|c|}
\hline & \multicolumn{3}{|l|}{$\mathrm{R}={ }^{\mathrm{t}} \mathrm{Bu}$} & \multicolumn{3}{|l|}{$\mathrm{R}={ }^{\mathrm{i}} \mathrm{Pr}$} & \multicolumn{3}{|l|}{$\mathrm{R}=\mathrm{Ph}$} & \multicolumn{3}{|l|}{$\mathrm{R}=\mathrm{Me}$} \\
\hline & $\mathrm{Ni}-\mathrm{C}_{i p s o}$ & Ni-P & $\mathrm{Ni}-\mathrm{Cl}$ & $\mathrm{Ni}-\mathrm{C}_{i p s o}$ & Ni-P & $\mathrm{Ni}-\mathrm{Cl}$ & $\mathrm{Ni}-\mathrm{C}_{i p s o}$ & Ni-P & $\mathrm{Ni}-\mathrm{Cl}$ & $\mathrm{Ni}-\mathrm{C}_{i p s o}$ & Ni-P & $\mathrm{Ni}-\mathrm{Cl}$ \\
\hline$\rho$ & 0.130 & 0.098 & 0.078 & 0.132 & 0.103 & 0.080 & 0.132 & 0.103 & 0.082 & 0.134 & 0.106 & 0.083 \\
\hline $\mathrm{V}$ & -0.173 & -0.116 & -0.108 & -0.177 & -0.126 & -0.111 & -0.178 & -0.127 & -0.113 & -0.181 & -0.133 & -0.116 \\
\hline
\end{tabular}

Table S5. Electron Density $\left(\rho, \mathrm{e} \mathbf{B o h r}^{3}\right)$ and Potential Energy Density (V, Hartree/Bohr $\left.{ }^{3}\right)$ at Bond Critical Point for Complexes [2,6- $\left.\left({ }^{\mathrm{i}} \mathrm{Pr}_{2} \mathrm{PO}\right)_{2} \mathrm{C}_{6} \mathrm{H}_{3}\right] \mathrm{NiX}(\mathrm{X}=\mathrm{F}, \mathrm{Cl}, \mathrm{Br}, \mathrm{I})$

\begin{tabular}{|c|c|c|c|c|c|c|c|c|c|c|c|c|}
\hline & \multicolumn{3}{|l|}{$X=F$} & \multicolumn{3}{|l|}{$\mathrm{X}=\mathrm{Cl}$} & \multicolumn{3}{|l|}{$\mathrm{X}=\mathrm{Br}$} & \multicolumn{3}{|l|}{$X=I$} \\
\hline & $\mathrm{Ni}-\mathrm{C}_{i p s o}$ & Ni-P & $\mathrm{Ni}-\mathrm{F}$ & $\mathrm{Ni}-\mathrm{C}_{i p s o}$ & Ni-P & $\mathrm{Ni}-\mathrm{Cl}$ & Ni-C $\mathrm{C}_{i p s o}$ & Ni-P & $\mathrm{Ni}-\mathrm{Br}$ & Ni-C $\mathrm{C}_{i p s o}$ & Ni-P & Ni-I \\
\hline$\rho$ & 0.133 & 0.103 & 0.100 & 0.132 & 0.103 & 0.080 & 0.130 & 0.105 & 0.072 & 0.132 & 0.104 & 0.064 \\
\hline $\mathrm{V}$ & -0.182 & -0.127 & -0.192 & -0.177 & -0.126 & -0.111 & -0.174 & -0.130 & -0.089 & -0.176 & -0.128 & -0.067 \\
\hline
\end{tabular}



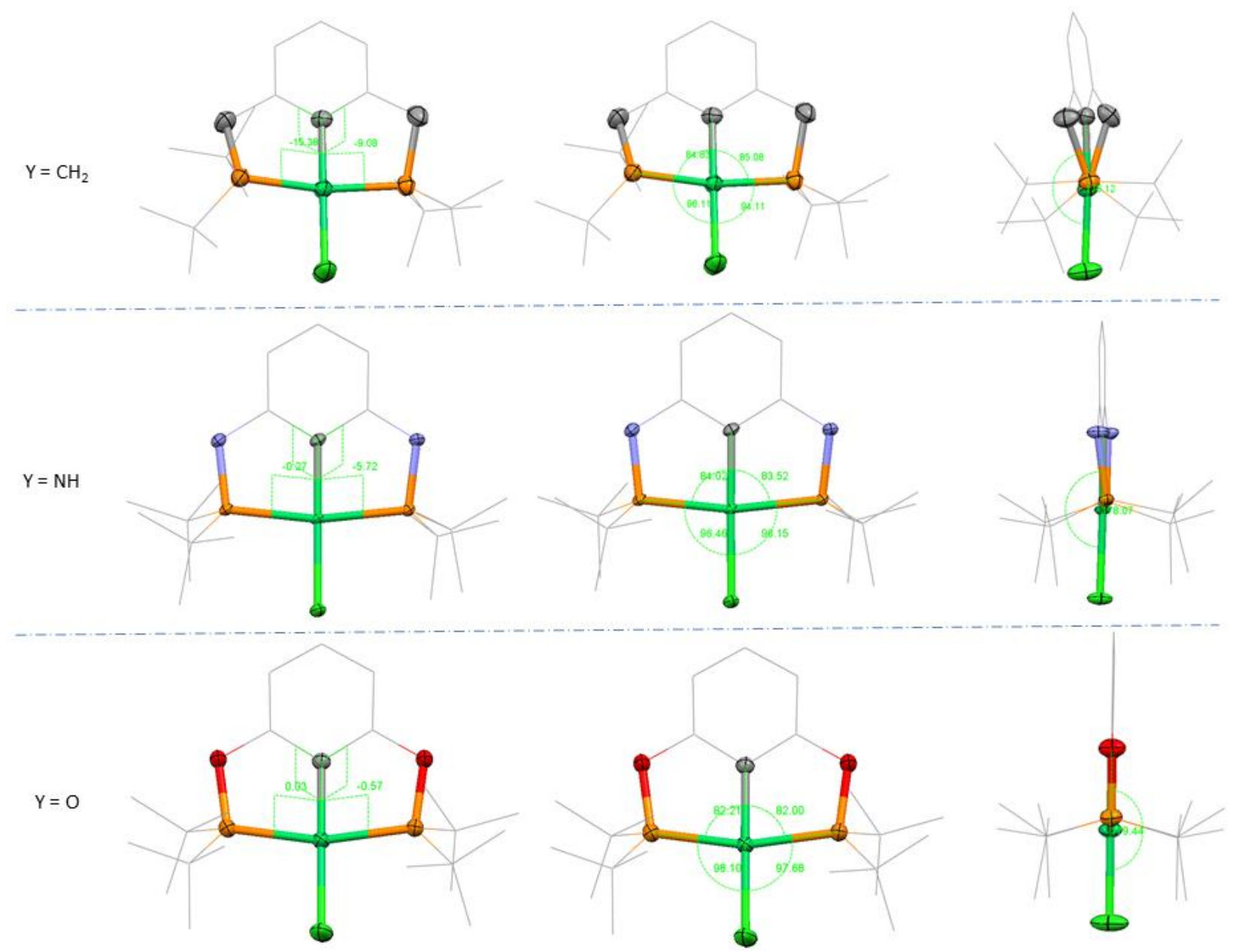

Figure S35. Views of molecular structure of $\left[2,6-\left({ }^{t} \mathrm{Bu}_{2} \mathrm{PY}\right)_{2} \mathrm{C}_{6} \mathrm{H}_{3}\right] \mathrm{NiCl}$ (hydrogen atoms have been omitted for clarity). 

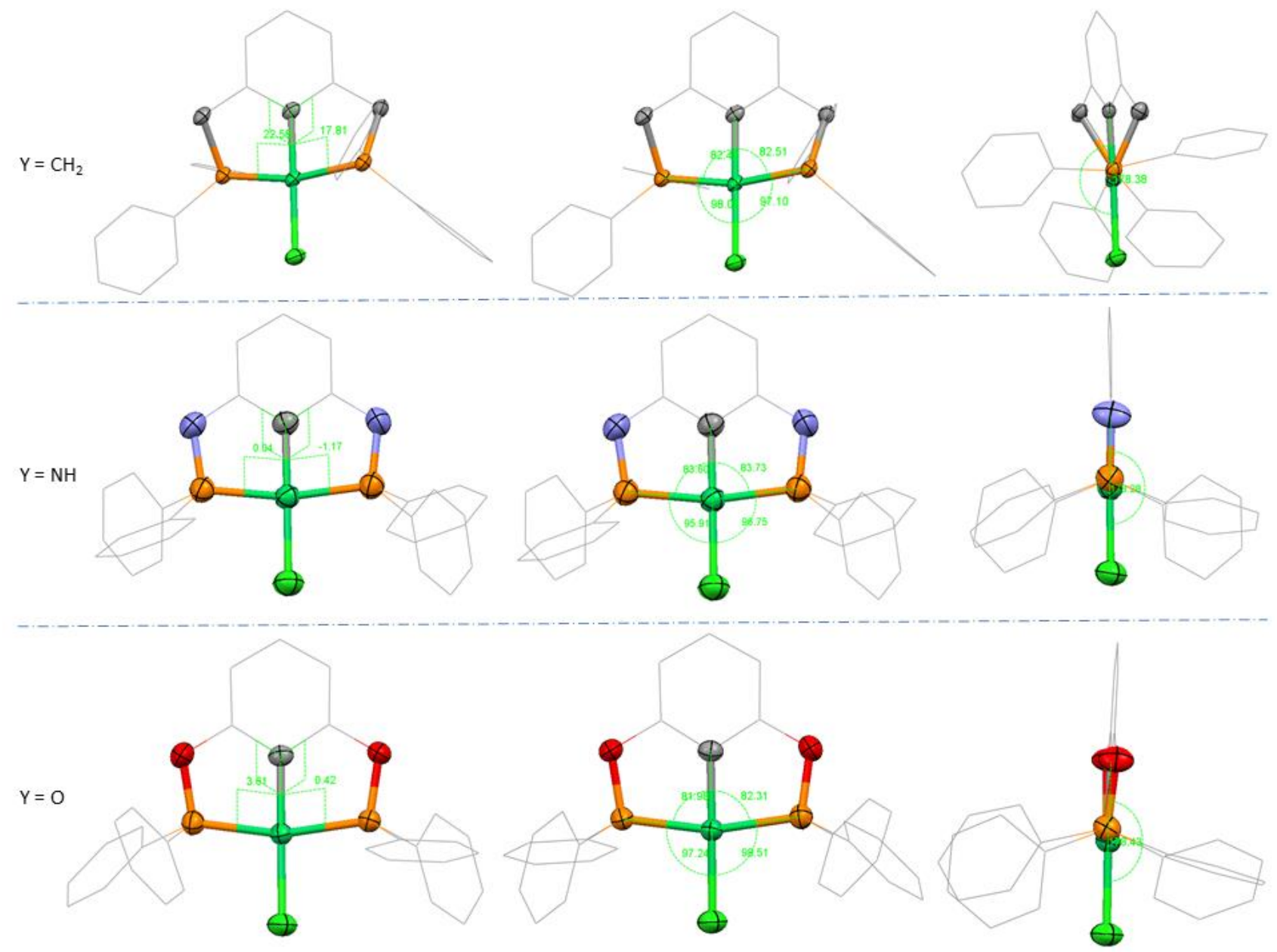

Figure S36. Views of molecular structure of $\left[2,6-\left(\mathrm{Ph}_{2} \mathrm{PY}\right)_{2} \mathrm{C}_{6} \mathrm{H}_{3}\right] \mathrm{NiCl}$ (hydrogen atoms have been omitted for clarity). 


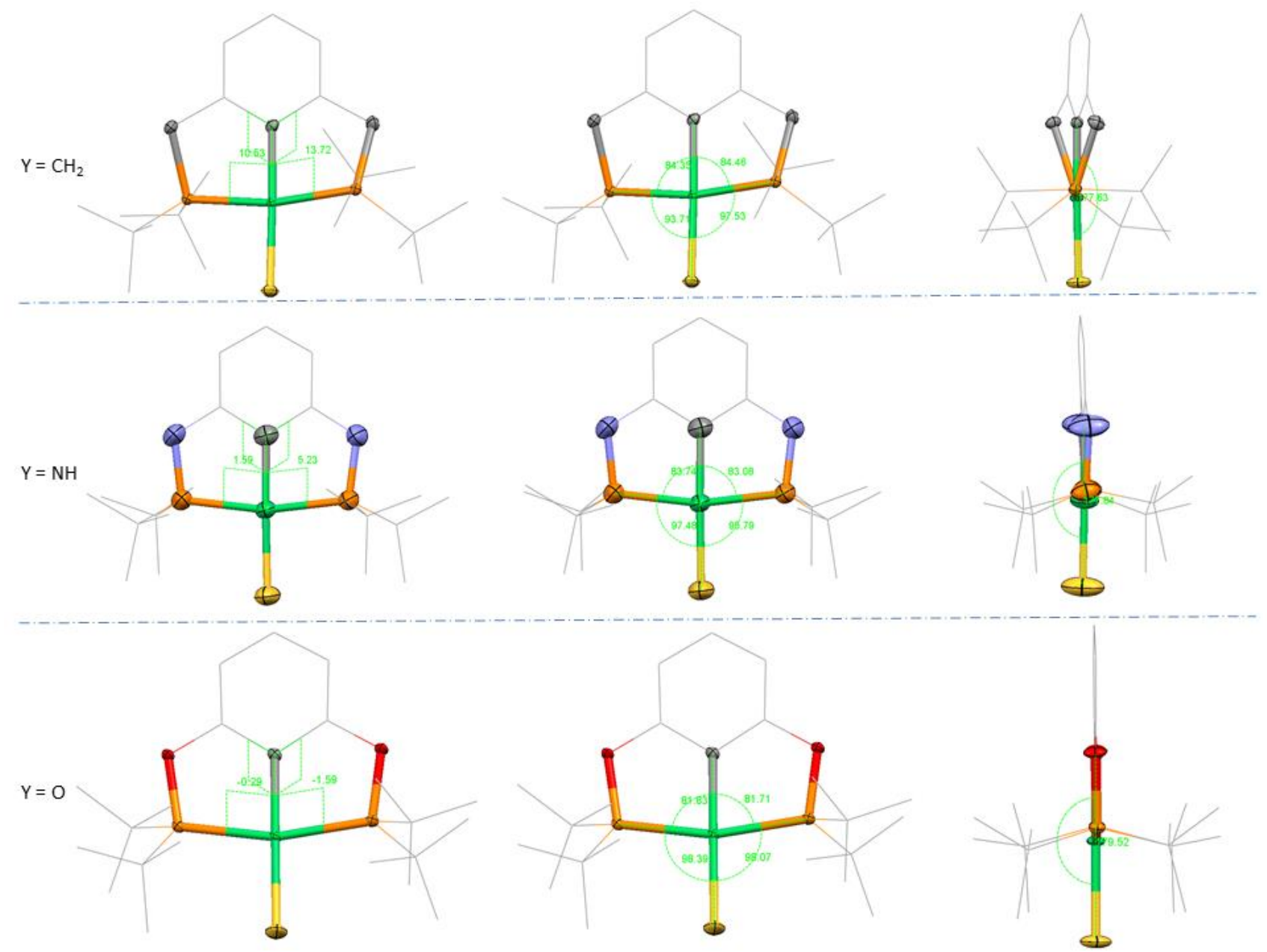

Figure S37. Views of molecular structure of $\left[2,6-\left({ }^{t} \mathrm{Bu}_{2} \mathrm{PY}\right)_{2} \mathrm{C}_{6} \mathrm{H}_{3}\right] \mathrm{NiSH}$ (hydrogen atoms have been omitted for clarity). 


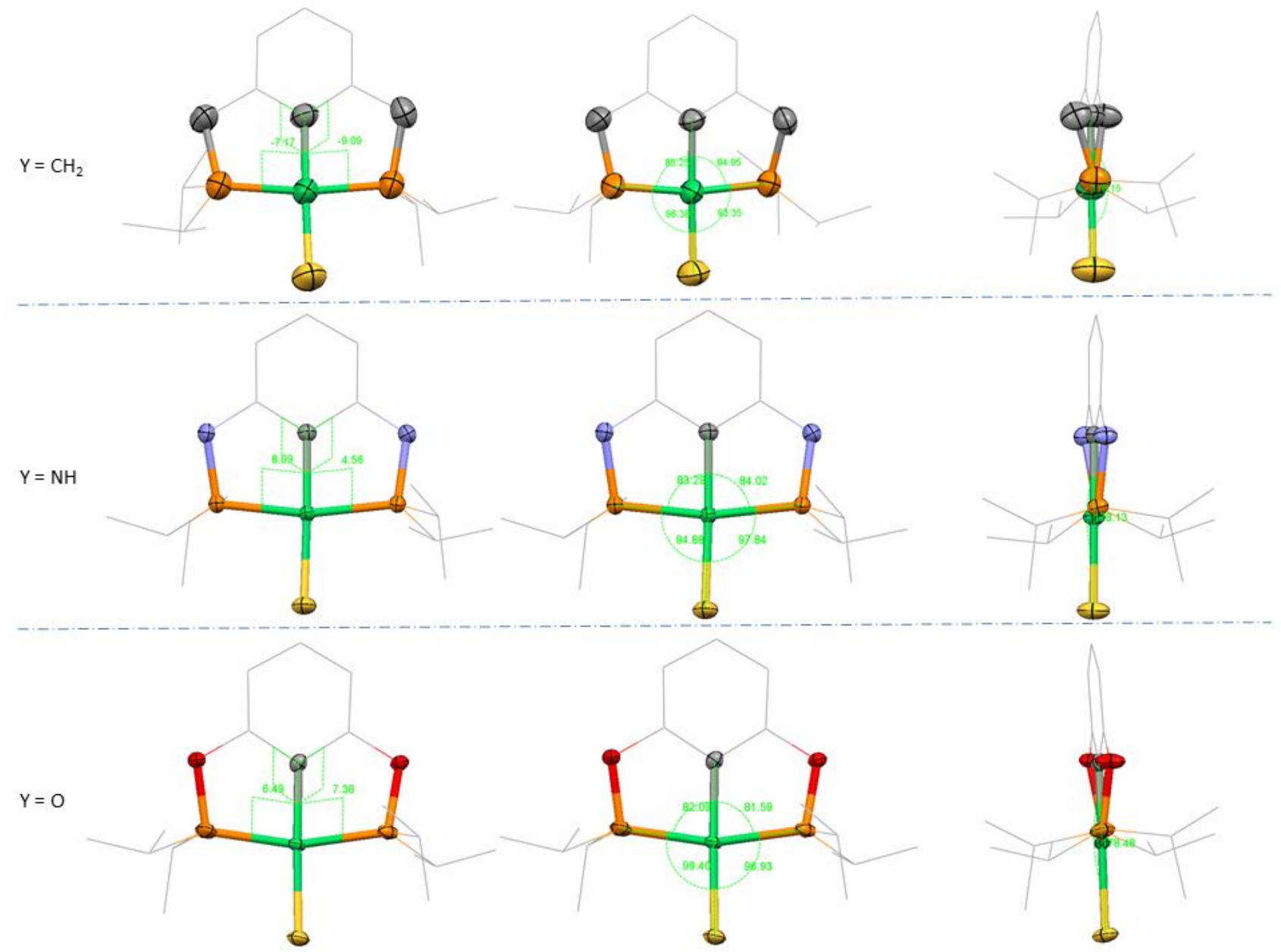

Figure S38. Views of molecular structure of $\left[2,6-\left({ }^{i} \mathrm{Pr}_{2} \mathrm{PY}\right)_{2} \mathrm{C}_{6} \mathrm{H}_{3}\right] \mathrm{NiSH}$ (hydrogen atoms have been omitted for clarity). 

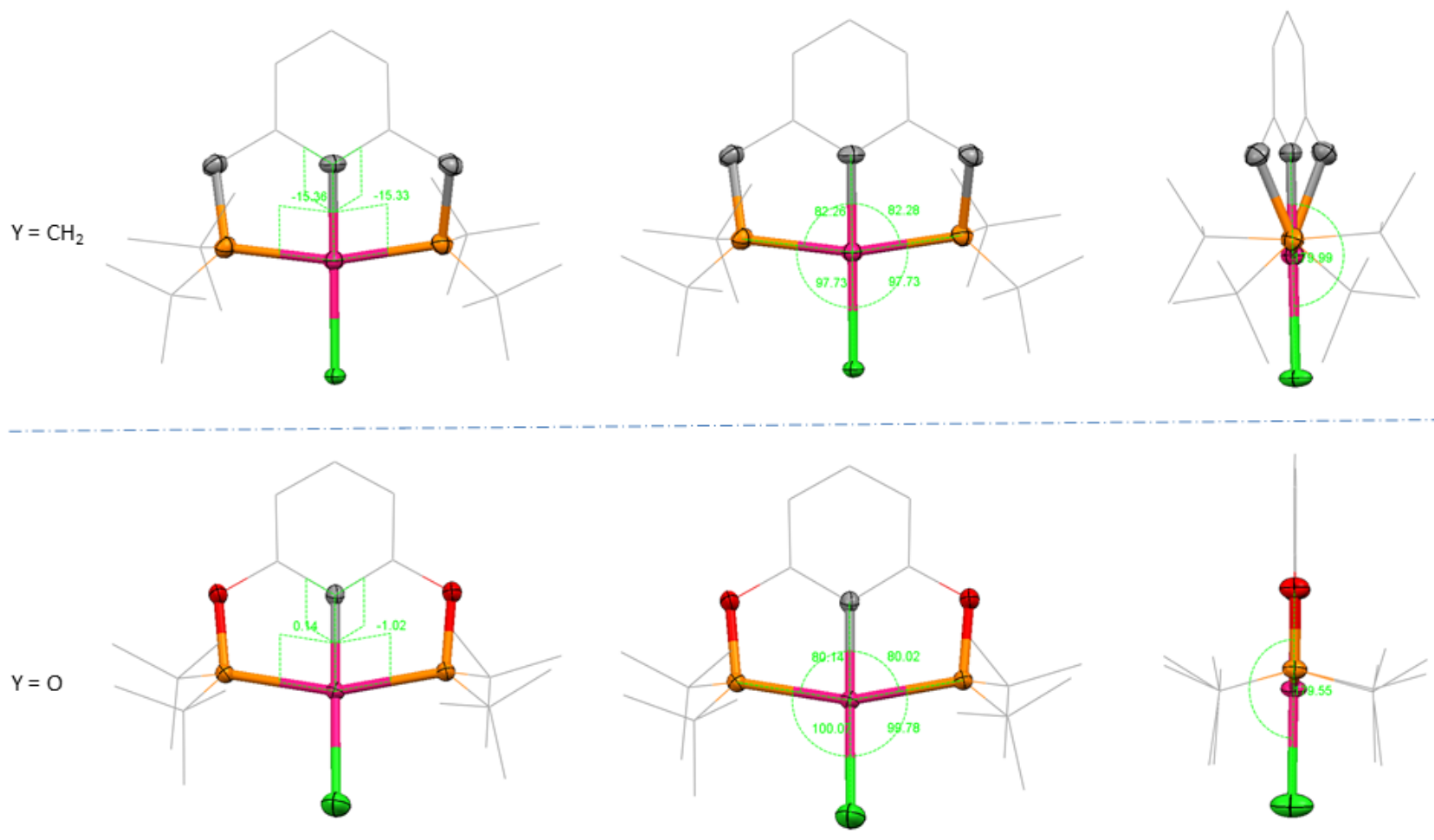

Figure S39. Views of molecular structure of $\left[2,6-\left({ }^{t} \mathrm{Bu}{ }_{2} \mathrm{PY}\right)_{2} \mathrm{C}_{6} \mathrm{H}_{3}\right] \mathrm{PdCl}$ (hydrogen atoms have been omitted for clarity). 

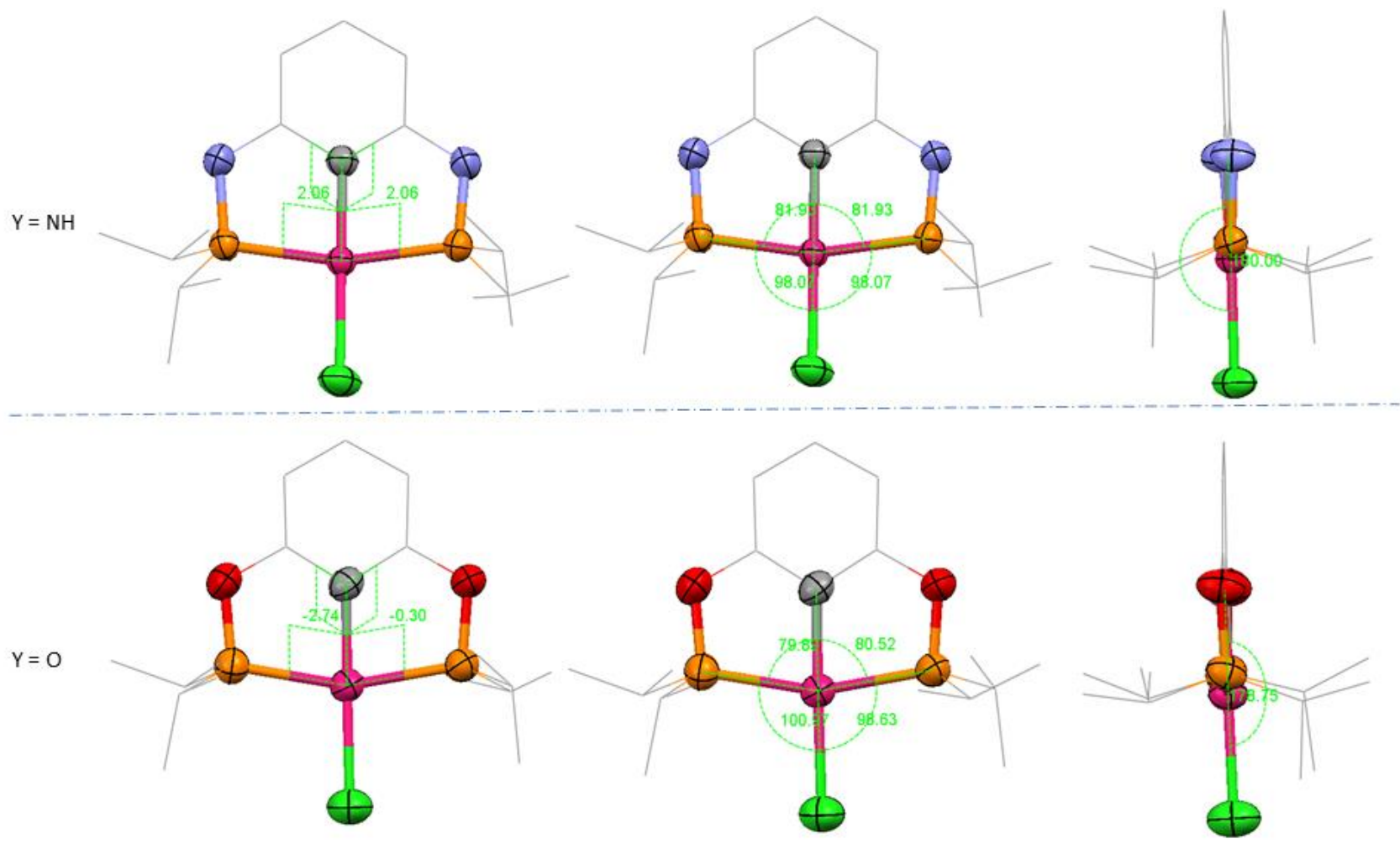

Figure S40. Views of molecular structure of $\left[2,6-\left({ }^{i} \mathrm{Pr}_{2} \mathrm{PY}\right)_{2} \mathrm{C}_{6} \mathrm{H}_{3}\right] \mathrm{PdCl}$ (hydrogen atoms have been omitted for clarity). 

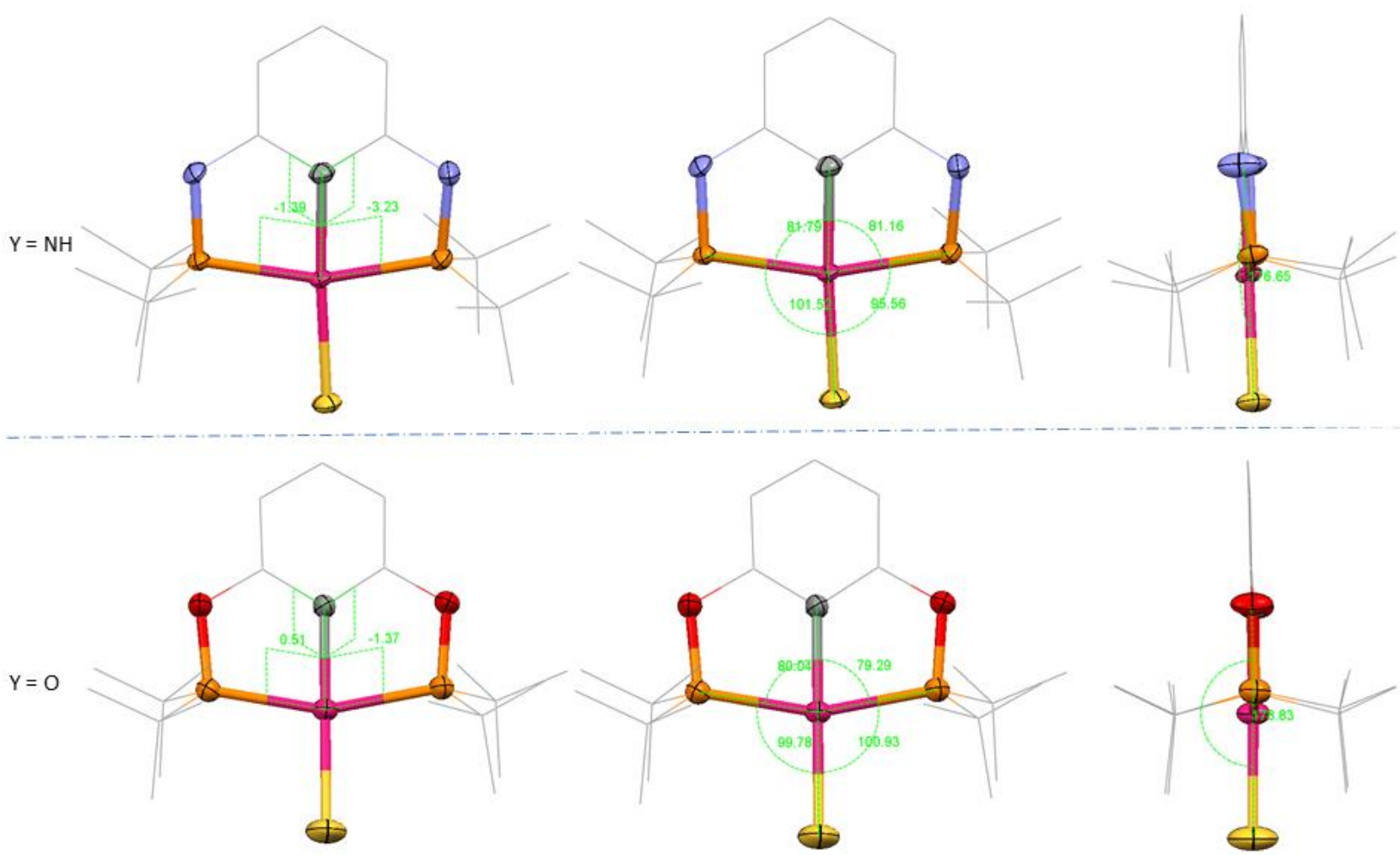

Figure S41. Views of molecular structure of $\left[2,6-\left({ }^{t} \mathrm{Bu}_{2} \mathrm{PY}\right)_{2} \mathrm{C}_{6} \mathrm{H}_{3}\right] \mathrm{PdSH}$ (hydrogen atoms have been omitted for clarity). 

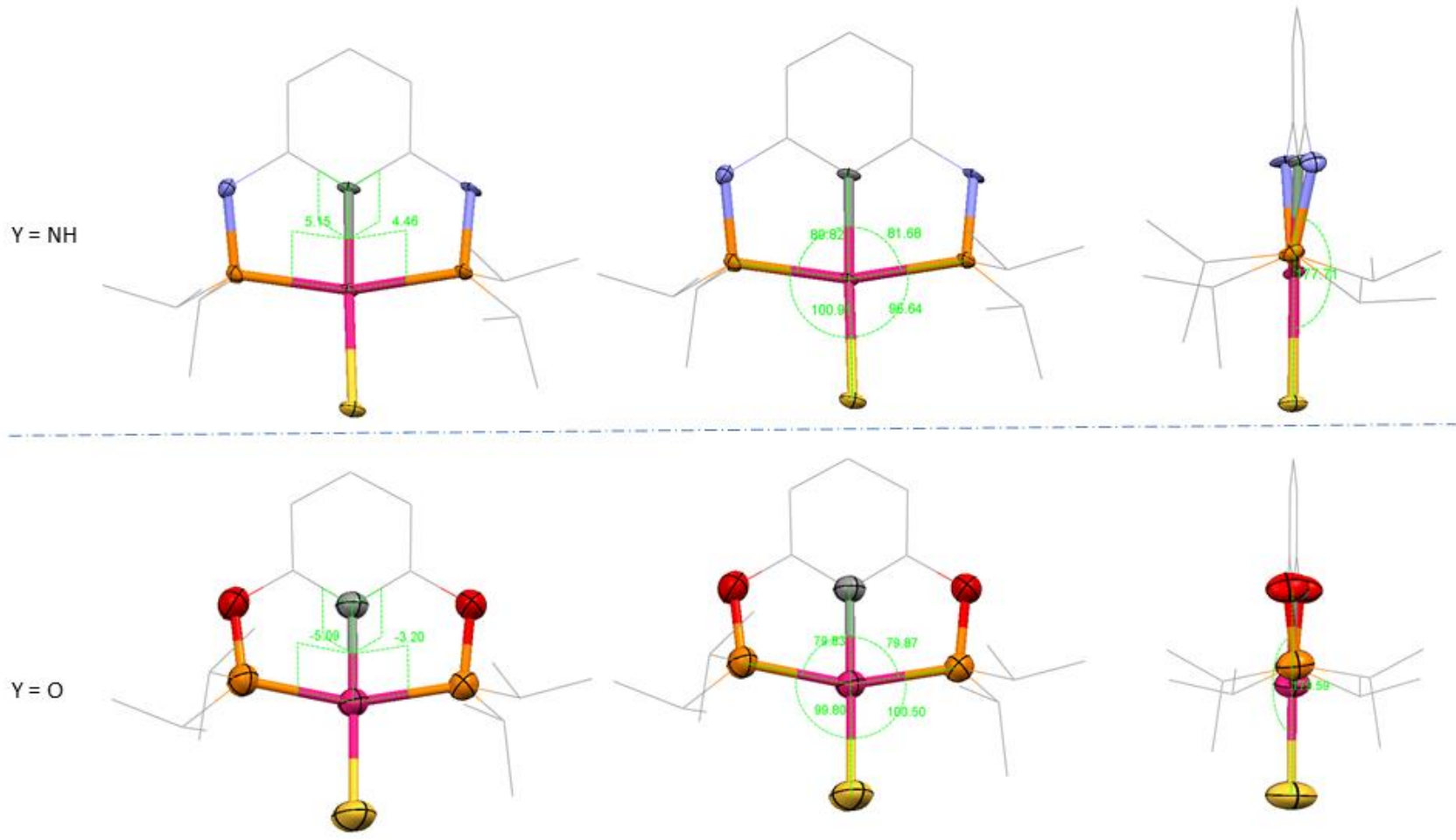

Figure S42. Views of molecular structure of $\left[2,6-\left({ }^{i} \mathrm{Pr}_{2} \mathrm{PY}\right)_{2} \mathrm{C}_{6} \mathrm{H}_{3}\right] \mathrm{PdSH}$ (hydrogen atoms have been omitted for clarity). 

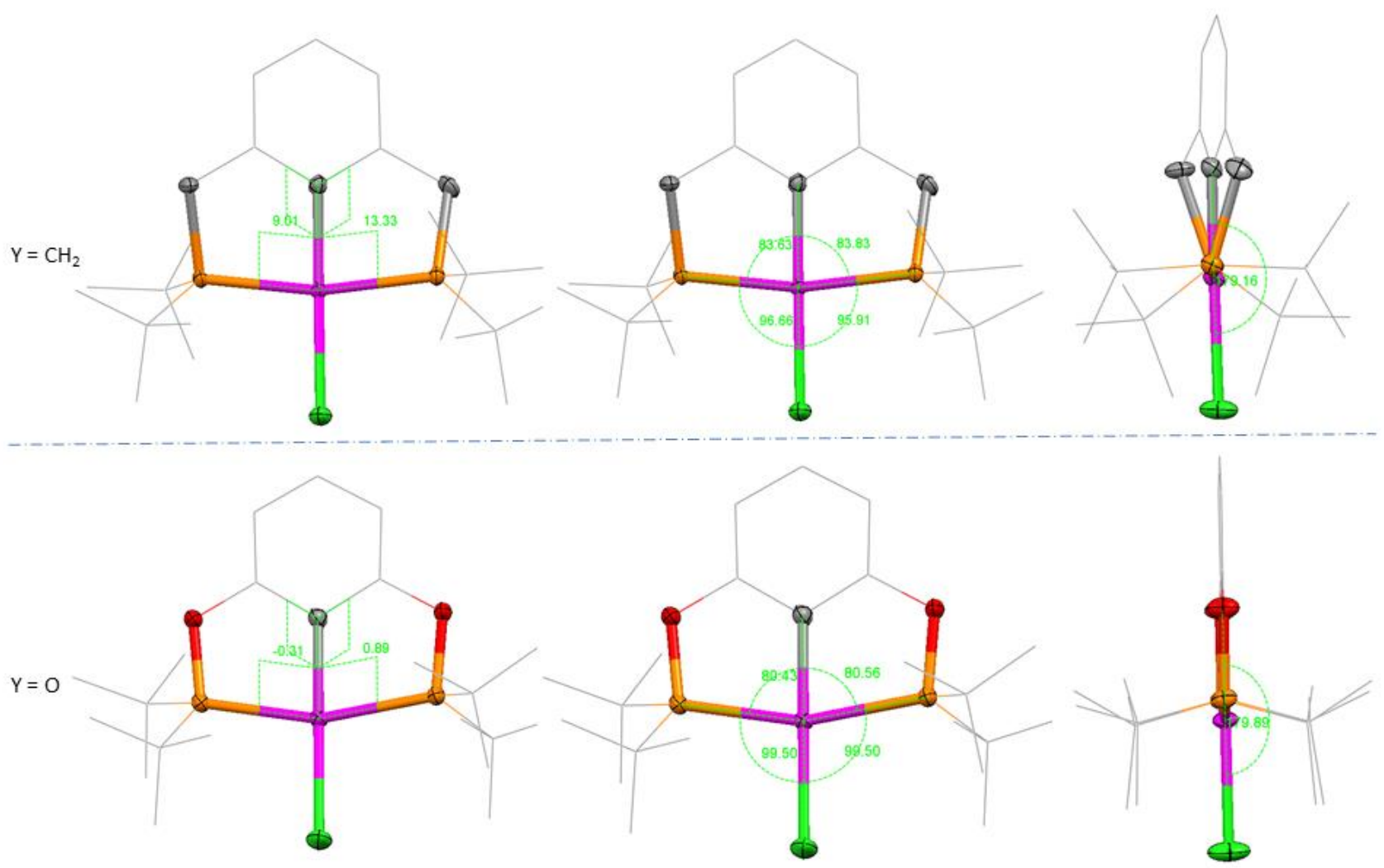

Figure S43. Views of molecular structure of $\left[2,6-\left({ }^{t} \mathrm{Bu}_{2} \mathrm{PY}\right)_{2} \mathrm{C}_{6} \mathrm{H}_{3}\right] \mathrm{PtCl}$ (hydrogen atoms have been omitted for clarity). 

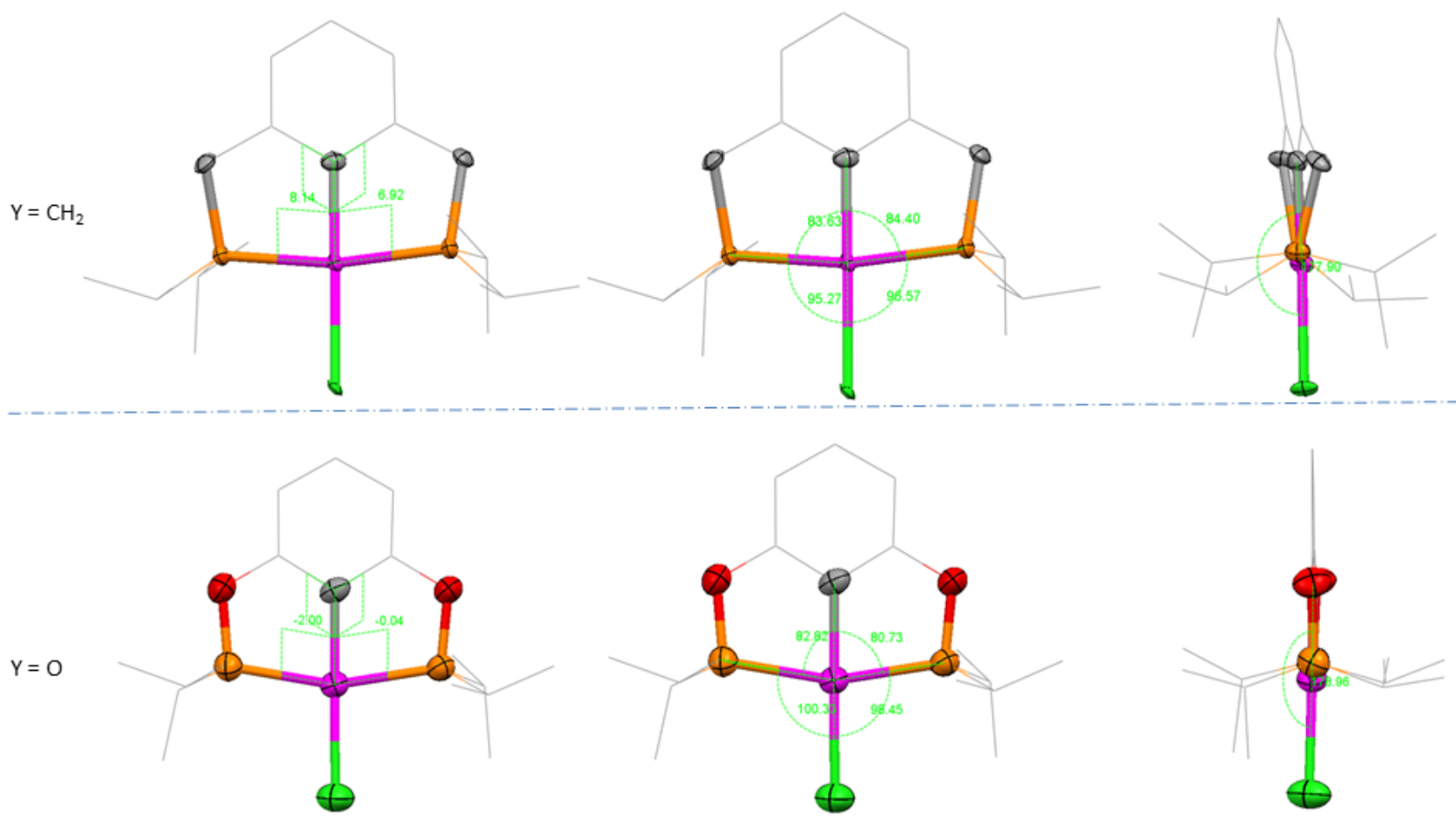

Figure S44. Views of molecular structure of $\left[2,6-\left({ }^{\mathrm{i}} \mathrm{Pr}_{2} \mathrm{PY}\right)_{2} \mathrm{C}_{6} \mathrm{H}_{3}\right] \mathrm{PtCl}$ (hydrogen atoms have been omitted for clarity). 
The Cartesian Coordinates of Optimized Structures

\begin{tabular}{|c|c|c|c|}
\hline \multicolumn{4}{|c|}{$\left[2,6-\left({ }^{t} \mathrm{Bu}_{2} \mathrm{PCH}_{2}\right)_{2} \mathrm{C}_{6} \mathrm{H}_{3}\right] \mathrm{NiCl}$} \\
\hline $\mathrm{Ni}$ & -0.01113000 & -0.27207600 & -0.03669900 \\
\hline $\mathrm{Cl}$ & 0.01731900 & -2.48110100 & -0.35282100 \\
\hline $\mathrm{P}$ & 2.16963700 & -0.10664900 & 0.11167400 \\
\hline $\mathrm{P}$ & -2.19842800 & -0.05955200 & -0.06760400 \\
\hline $\mathrm{C}$ & -0.00093800 & 1.64610600 & 0.11114300 \\
\hline $\mathrm{C}$ & 1.17747400 & 2.35525700 & 0.42984400 \\
\hline $\mathrm{C}$ & 1.21651400 & 3.74551600 & 0.38993800 \\
\hline $\mathrm{H}$ & 2.14740500 & 4.25853500 & 0.61949200 \\
\hline $\mathrm{C}$ & 0.10058800 & 4.46563600 & 0.07054800 \\
\hline $\mathrm{H}$ & 0.13734400 & 5.55017400 & 0.03649600 \\
\hline $\mathrm{C}$ & -1.09255800 & 3.80464100 & -0.19622700 \\
\hline $\mathrm{H}$ & -1.98840400 & 4.37163600 & -0.43430500 \\
\hline $\mathrm{C}$ & -1.13924800 & 2.40908100 & -0.17189100 \\
\hline $\mathrm{C}$ & -2.43079900 & 1.70850400 & -0.49616100 \\
\hline $\mathrm{H}$ & -2.62560100 & 1.76281400 & -1.57160700 \\
\hline $\mathrm{H}$ & -3.29550400 & 2.15636400 & 0.00411000 \\
\hline $\mathrm{C}$ & 2.39263300 & 1.56486200 & 0.82456500 \\
\hline $\mathrm{H}$ & 2.41875200 & 1.45089700 & 1.91381600 \\
\hline $\mathrm{H}$ & 3.33279300 & 2.04144900 & 0.53099600 \\
\hline $\mathrm{C}$ & 3.02308900 & -0.03840100 & -1.55296200 \\
\hline $\mathrm{C}$ & 2.70413700 & -1.28613900 & -2.37048100 \\
\hline $\mathrm{H}$ & 1.62616500 & -1.41902900 & -2.48519400 \\
\hline $\mathrm{H}$ & 3.09512000 & -2.20017300 & -1.92215800 \\
\hline $\mathrm{H}$ & 3.15276100 & -1.17950500 & -3.36476000 \\
\hline $\mathrm{C}$ & 4.54163300 & 0.12980800 & -1.42675400 \\
\hline $\mathrm{H}$ & 5.01651500 & -0.75845400 & -1.00571000 \\
\hline $\mathrm{H}$ & 4.81899900 & 0.99505000 & -0.81811000 \\
\hline $\mathrm{H}$ & 4.96492700 & 0.28432700 & -2.42606400 \\
\hline $\mathrm{C}$ & 2.44784500 & 1.16494500 & -2.30452100 \\
\hline $\mathrm{H}$ & 2.86469600 & 1.17540200 & -3.31775500 \\
\hline $\mathrm{H}$ & 2.69380200 & 2.11886000 & -1.83125400 \\
\hline $\mathrm{H}$ & 1.35869900 & 1.10494900 & -2.38002000 \\
\hline $\mathrm{C}$ & 3.05931000 & -1.23604600 & 1.31736200 \\
\hline $\mathrm{C}$ & 4.34865000 & -0.62029000 & 1.87709800 \\
\hline $\mathrm{H}$ & 4.77604100 & -1.31832500 & 2.60585100 \\
\hline $\mathrm{H}$ & 4.17077000 & 0.32215500 & 2.40058400 \\
\hline $\mathrm{H}$ & 5.10436600 & -0.44595400 & 1.11028700 \\
\hline $\mathrm{C}$ & 3.38023900 & -2.61364200 & 0.72361300 \\
\hline $\mathrm{H}$ & 4.16323000 & -2.55620500 & -0.03686700 \\
\hline $\mathrm{H}$ & 2.49475100 & -3.08068000 & 0.28916500 \\
\hline & & S35 & \\
\hline
\end{tabular}




\begin{tabular}{|c|c|c|c|}
\hline $\mathrm{H}$ & 3.75207800 & -3.25974900 & 1.52679700 \\
\hline $\mathrm{C}$ & 2.07057200 & -1.43266100 & 2.48829200 \\
\hline $\mathrm{H}$ & 2.55446200 & -2.03068300 & 3.26845100 \\
\hline $\mathrm{H}$ & 1.17260600 & -1.95532400 & 2.15096000 \\
\hline $\mathrm{H}$ & 1.76742400 & -0.48115400 & 2.93787500 \\
\hline $\mathrm{C}$ & -3.17034400 & -0.95168100 & -1.39945400 \\
\hline $\mathrm{C}$ & -2.27039200 & -0.88693400 & -2.65049700 \\
\hline $\mathrm{H}$ & -2.79579200 & -1.35139800 & -3.49249100 \\
\hline $\mathrm{H}$ & -1.33423900 & -1.42343800 & -2.48259700 \\
\hline $\mathrm{H}$ & -2.03381300 & 0.14321800 & -2.93596800 \\
\hline $\mathrm{C}$ & -4.51118600 & -0.28152000 & -1.72777600 \\
\hline $\mathrm{H}$ & -4.97664800 & -0.82898900 & -2.55528600 \\
\hline $\mathrm{H}$ & -4.39809200 & 0.75579600 & -2.05178100 \\
\hline $\mathrm{H}$ & -5.20944600 & -0.30148200 & -0.89028400 \\
\hline $\mathrm{C}$ & -2.94977100 & -0.28492100 & 1.63605300 \\
\hline $\mathrm{C}$ & -2.33748100 & 0.79857200 & 2.53271600 \\
\hline $\mathrm{H}$ & -2.62188900 & 1.80843500 & 2.22572500 \\
\hline $\mathrm{H}$ & -1.24497200 & 0.74802800 & 2.52969400 \\
\hline $\mathrm{H}$ & -2.68954500 & 0.64627600 & 3.55895200 \\
\hline $\mathrm{C}$ & -4.47261800 & -0.12739700 & 1.66312000 \\
\hline $\mathrm{H}$ & -4.97894500 & -0.93917100 & 1.13672800 \\
\hline $\mathrm{H}$ & -4.80023300 & 0.82429900 & 1.23386600 \\
\hline $\mathrm{H}$ & -4.81187800 & -0.15126000 & 2.70502400 \\
\hline $\mathrm{C}$ & -2.55752400 & -1.64614000 & 2.19416000 \\
\hline $\mathrm{H}$ & -2.90677000 & -1.72180200 & 3.23036300 \\
\hline $\mathrm{H}$ & -1.47299200 & -1.78220500 & 2.18132400 \\
\hline $\mathrm{H}$ & -2.99245100 & -2.47390000 & 1.63195600 \\
\hline $\mathrm{C}$ & -3.43373600 & -2.41958800 & -1.04904100 \\
\hline $\mathrm{H}$ & -4.16335800 & -2.51733900 & -0.24098200 \\
\hline $\mathrm{H}$ & -2.51658700 & -2.93918900 & -0.76745600 \\
\hline $\mathrm{H}$ & -3.85398500 & -2.91882200 & -1.92951800 \\
\hline \multicolumn{4}{|c|}{ 6-( $\left.\left.{ }^{t} \mathrm{Bu}_{2} \mathrm{PNH}\right)_{2} \mathrm{C}_{6} \mathrm{H}_{3}\right] \mathrm{NiCl}$} \\
\hline $\mathrm{Ni}$ & -0.00448100 & -0.31318700 & -0.09481500 \\
\hline $\mathrm{Cl}$ & -0.01140100 & -2.54452600 & -0.13368100 \\
\hline $\mathrm{P}$ & 2.19362100 & -0.07271300 & 0.00034000 \\
\hline $\mathrm{P}$ & -2.19120000 & -0.07178700 & -0.03329200 \\
\hline $\mathrm{N}$ & 2.37532400 & 1.60670400 & 0.01884800 \\
\hline $\mathrm{H}$ & 3.25520100 & 2.09412100 & 0.03011200 \\
\hline $\mathrm{N}$ & -2.39216400 & 1.59140700 & -0.26764400 \\
\hline $\mathrm{H}$ & -3.27074400 & 2.07083300 & -0.15723300 \\
\hline $\mathrm{C}$ & -0.01165400 & 1.59863100 & -0.12450500 \\
\hline $\mathrm{C}$ & 1.18491200 & 2.33297600 & -0.07634100 \\
\hline
\end{tabular}




\begin{tabular}{|c|c|c|c|}
\hline $\mathrm{C}$ & 1.19672000 & 3.72885900 & -0.09151500 \\
\hline $\mathrm{H}$ & 2.13483700 & 4.27331400 & -0.03830000 \\
\hline $\mathrm{C}$ & -0.01081400 & 4.41569300 & -0.18320100 \\
\hline $\mathrm{H}$ & -0.00765100 & 5.50089900 & -0.20089400 \\
\hline $\mathrm{C}$ & -1.22255900 & 3.73149000 & -0.25388000 \\
\hline $\mathrm{H}$ & -2.16104800 & 4.27189700 & -0.32846700 \\
\hline $\mathrm{C}$ & -1.20364200 & 2.33403200 & -0.21927300 \\
\hline $\mathrm{C}$ & 3.15978100 & -0.61905600 & -1.51270200 \\
\hline $\mathrm{C}$ & 3.10690200 & -2.13435000 & -1.73648600 \\
\hline $\mathrm{H}$ & 3.56178200 & -2.35488900 & -2.70889200 \\
\hline $\mathrm{H}$ & 2.07997700 & -2.50331100 & -1.73922900 \\
\hline $\mathrm{H}$ & 2.42945600 & -2.68832400 & -0.97849000 \\
\hline $\mathrm{C}$ & 2.91688600 & 0.07054000 & -2.68561100 \\
\hline $\mathrm{H}$ & 2.45363100 & -0.21310900 & -3.62441100 \\
\hline $\mathrm{H}$ & 1.38205600 & 1.15952900 & -2.59774900 \\
\hline $\mathrm{H}$ & 4.62072300 & -0.24262700 & -2.73162300 \\
\hline $\mathrm{C}$ & 5.07534700 & -0.14385500 & -1.47955500 \\
\hline $\mathrm{H}$ & 5.20897000 & -0.32830300 & -2.45948300 \\
\hline $\mathrm{H}$ & 4.71125000 & -0.69212600 & -0.74055000 \\
\hline $\mathrm{H}$ & 2.99507000 & 0.92825000 & -1.28062900 \\
\hline $\mathrm{C}$ & 3.28284000 & -0.60523300 & 1.61477000 \\
\hline $\mathrm{C}$ & 3.52374500 & -2.11107500 & 1.66107000 \\
\hline $\mathrm{H}$ & 4.14103500 & -2.38999000 & 2.69274100 \\
\hline $\mathrm{H}$ & 2.41747000 & -2.37942200 & 1.03987100 \\
\hline $\mathrm{H}$ & 1.94400300 & -2.69741400 & 1.34005700 \\
\hline $\mathrm{C}$ & 2.36957100 & -0.27445800 & 2.69136600 \\
\hline $\mathrm{H}$ & 1.05842900 & -0.46453900 & 3.68296900 \\
\hline $\mathrm{H}$ & 1.63302000 & -0.90424200 & 2.56769100 \\
\hline $\mathrm{H}$ & 4.26959500 & 0.77379800 & 2.64475300 \\
\hline $\mathrm{C}$ & 4.65192300 & 0.17752700 & 1.92398800 \\
\hline $\mathrm{H}$ & 4.07634600 & -0.14796600 & 2.89812700 \\
\hline $\mathrm{H}$ & 2.42945600 & 1.25124100 & 1.99799000 \\
\hline $\mathrm{H}$ & 5.06251300 & 0.01168800 & 1.19313600 \\
\hline $\mathrm{C}$ & -3.18900900 & -0.79158600 & -1.42585900 \\
\hline $\mathrm{C}$ & -3.46062600 & -2.28740500 & -1.22861700 \\
\hline $\mathrm{H}$ & -3.85027900 & -2.69853500 & -2.16644900 \\
\hline $\mathrm{H}$ & -4.21594600 & -2.46207900 & -0.45818700 \\
\hline $\mathrm{H}$ & -2.55231600 & -2.83473800 & -0.96739300 \\
\hline $\mathrm{C}$ & -2.32254200 & -0.59433000 & -2.67913500 \\
\hline $\mathrm{H}$ & -2.87914700 & -0.93121800 & -3.56033600 \\
\hline $\mathrm{H}$ & -1.39917700 & -1.17682600 & -2.60670300 \\
\hline $\mathrm{H}$ & -2.05787600 & 0.45805100 & -2.81919100 \\
\hline $\mathrm{C}$ & -4.53197500 & -0.05807900 & -1.64669800 \\
\hline
\end{tabular}




$\begin{array}{lrrr}\mathrm{H} & -5.03320400 & -0.51254100 & -2.50804200 \\ \mathrm{H} & -4.37708500 & 0.99861500 & -1.88015700 \\ \mathrm{H} & -5.20663000 & -0.13962300 & -0.79361100 \\ \mathrm{C} & -2.92980800 & -0.41522800 & 1.65031100 \\ \mathrm{C} & -2.77452700 & -1.88814000 & 2.04289400 \\ \mathrm{H} & -3.06117500 & -1.99901700 & 3.09497600 \\ \mathrm{H} & -1.74384300 & -2.22953700 & 1.92548800 \\ \mathrm{H} & -3.41222600 & -2.54892900 & 1.45549800 \\ \mathrm{C} & -2.08537600 & 0.42916000 & 2.61837800 \\ \mathrm{H} & -2.43352400 & 0.25284000 & 3.64182300 \\ \mathrm{H} & -2.16434400 & 1.49915000 & 2.40800900 \\ \mathrm{H} & -1.02814800 & 0.15798000 & 2.56081000 \\ \mathrm{C} & -4.40858800 & -0.00359900 & 1.77901700 \\ \mathrm{H} & -4.70299200 & -0.07726100 & 2.83164200 \\ \mathrm{H} & -5.06480800 & -0.66371900 & 1.20819900 \\ \mathrm{H} & -4.58607200 & 1.02991300 & 1.46487100\end{array}$

\section{$\left[2,6-\left({ }^{t} \mathrm{Bu}_{2} \mathrm{PO}\right)_{2} \mathrm{C}_{6} \mathrm{H}_{3}\right] \mathrm{NiCl}$}

$\begin{array}{rrrr}\mathrm{Ni} & -0.00607100 & -0.38592200 & -0.02836600 \\ \mathrm{Cl} & -0.00497700 & -2.59030800 & 0.01022100 \\ \mathrm{P} & 2.16310600 & -0.07580300 & -0.01808600 \\ \mathrm{P} & -2.17305900 & -0.09435600 & -0.00681200 \\ \mathrm{O} & 2.36901300 & 1.57145800 & -0.04871800 \\ \mathrm{O} & -2.40035100 & 1.54468600 & -0.02174900 \\ \mathrm{C} & -0.01735100 & 1.50142700 & -0.04627800 \\ \mathrm{C} & 1.16052200 & 2.25956000 & -0.04701000 \\ \mathrm{C} & 1.17774900 & 3.64434800 & -0.05199100 \\ \mathrm{H} & 2.12449000 & 4.17144100 & -0.05298700 \\ \mathrm{C} & -0.03121000 & 4.31589300 & -0.07265300 \\ \mathrm{H} & -0.03745900 & 5.40085500 & -0.08409400 \\ \mathrm{C} & -1.23821200 & 3.62956500 & -0.06632200 \\ \mathrm{H} & -2.19058200 & 4.14595600 & -0.07251200 \\ \mathrm{C} & -1.20090300 & 2.24632500 & -0.05172900 \\ \mathrm{C} & 3.07294400 & -0.56905200 & -1.56432500 \\ \mathrm{C} & 4.35536000 & 0.21668300 & -1.78934600 \\ \mathrm{H} & 4.80572200 & -0.11911500 & -2.73013700 \\ \mathrm{H} & 5.08382000 & 0.05553200 & -0.99605200 \\ \mathrm{H} & 4.17708200 & 1.29288400 & -1.86923600 \\ \mathrm{C} & 3.55209700 & -2.02456100 & -1.45440500 \\ \mathrm{H} & 3.9194500 & -2.34236200 & -2.43839000 \\ \mathrm{H} & 2.75414300 & -2.71227700 & -1.15719200 \\ \mathrm{H} & 4.38287700 & -2.11952300 & -0.75422800 \\ \mathrm{C} & 2.08498300 & -0.41804600 & -2.72587700\end{array}$




\begin{tabular}{|c|c|c|c|}
\hline $\mathrm{H}$ & 2.58667700 & -0.68001300 & -3.66351300 \\
\hline $\mathrm{H}$ & 1.71751400 & 0.60932600 & -2.81058900 \\
\hline $\mathrm{H}$ & 1.22709600 & -1.08276800 & -2.58893700 \\
\hline $\mathrm{C}$ & 3.07503000 & -0.49366700 & 1.55531300 \\
\hline $\mathrm{C}$ & 4.49343100 & 0.03930600 & 1.60695800 \\
\hline $\mathrm{H}$ & 4.86801300 & -0.05481600 & 2.63245800 \\
\hline $\mathrm{H}$ & 4.54471300 & 1.09465800 & 1.32611100 \\
\hline $\mathrm{H}$ & 5.17286500 & -0.52712100 & 0.96564300 \\
\hline $\mathrm{C}$ & 2.26611600 & 0.21572300 & 2.65407000 \\
\hline $\mathrm{H}$ & 2.71167400 & -0.01785800 & 3.62658200 \\
\hline $\mathrm{H}$ & 1.22446900 & -0.11869000 & 2.66640300 \\
\hline $\mathrm{H}$ & 2.27577800 & 1.30047900 & 2.52239300 \\
\hline $\mathrm{C}$ & 3.07198900 & -2.00375600 & 1.79835100 \\
\hline $\mathrm{H}$ & 3.43253000 & -2.18680700 & 2.81730800 \\
\hline $\mathrm{H}$ & 3.73215800 & -2.53894800 & 1.11770800 \\
\hline $\mathrm{H}$ & 2.07039200 & -2.43101100 & 1.70966200 \\
\hline $\mathrm{C}$ & -3.01004800 & -0.54250100 & 1.59300400 \\
\hline $\mathrm{C}$ & -1.93212300 & -0.31253000 & 2.66730700 \\
\hline $\mathrm{H}$ & -2.36228200 & -0.50924300 & 3.65557000 \\
\hline $\mathrm{H}$ & -1.56236100 & 0.71736600 & 2.65593200 \\
\hline $\mathrm{H}$ & -1.08415400 & -0.98738700 & 2.51777700 \\
\hline $\mathrm{C}$ & -3.42172700 & -2.01944000 & 1.60470800 \\
\hline $\mathrm{H}$ & -3.71995700 & -2.28948900 & 2.62359000 \\
\hline $\mathrm{H}$ & -2.59684900 & -2.67428500 & 1.30900900 \\
\hline $\mathrm{H}$ & -4.27726400 & -2.20599000 & 0.95152300 \\
\hline $\mathrm{C}$ & -4.22187400 & 0.33944000 & 1.91140200 \\
\hline $\mathrm{H}$ & -4.58516300 & 0.07529000 & 2.91061100 \\
\hline $\mathrm{H}$ & -5.04394300 & 0.19134100 & 1.20969000 \\
\hline $\mathrm{H}$ & -3.95749600 & 1.39868500 & 1.91060300 \\
\hline $\mathrm{C}$ & -3.13736400 & -0.57931200 & -1.51749300 \\
\hline $\mathrm{C}$ & -2.45095500 & 0.16339500 & -2.67813900 \\
\hline $\mathrm{H}$ & -2.92903900 & -0.13188700 & -3.61764700 \\
\hline $\mathrm{H}$ & -1.38748100 & -0.08901300 & -2.74093900 \\
\hline $\mathrm{H}$ & -2.53924400 & 1.24701600 & -2.57030000 \\
\hline $\mathrm{C}$ & -4.59827000 & -0.15717200 & -1.47012300 \\
\hline $\mathrm{H}$ & -5.04814300 & -0.32670500 & -2.45473600 \\
\hline $\mathrm{H}$ & -4.70712800 & 0.90373200 & -1.22886200 \\
\hline $\mathrm{H}$ & -5.17164500 & -0.74200200 & -0.74646200 \\
\hline $\mathrm{C}$ & -3.03379500 & -2.09118100 & -1.76556800 \\
\hline $\mathrm{H}$ & -3.50143800 & -2.31201000 & -2.73161800 \\
\hline $\mathrm{H}$ & -3.55219500 & -2.67612200 & -1.00538100 \\
\hline $\mathrm{H}$ & -1.99589200 & -2.42751800 & -1.79619600 \\
\hline
\end{tabular}




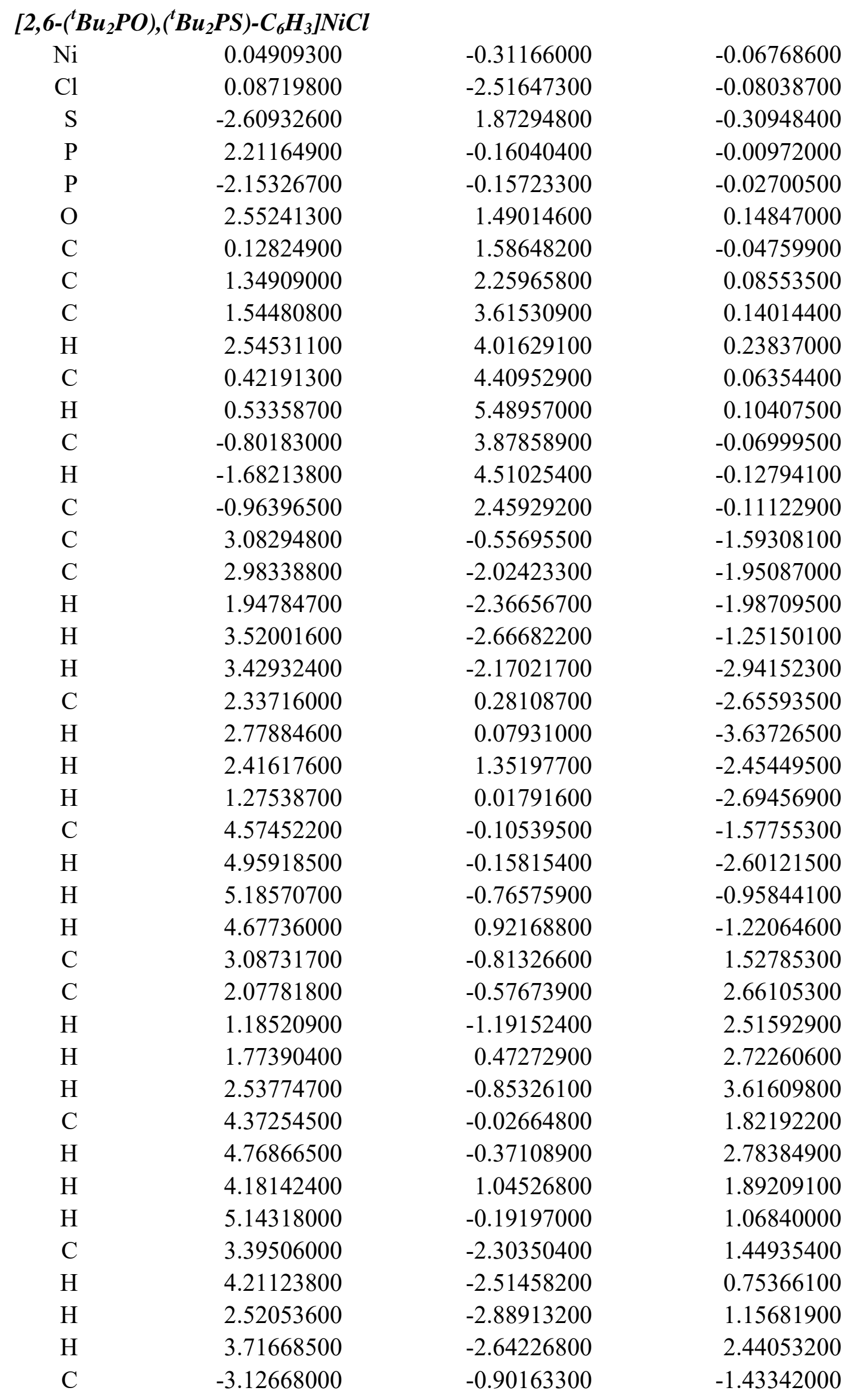




$\begin{array}{lrrr}\mathrm{C} & -2.33790300 & -0.58764700 & -2.71116300 \\ \mathrm{H} & -1.35198200 & -1.06213900 & -2.68504300 \\ \mathrm{H} & -2.20265300 & 0.48821400 & -2.85294700 \\ \mathrm{H} & -2.88731900 & -0.98145400 & -3.57237800 \\ \mathrm{C} & -3.24173600 & -2.40878500 & -1.29767800 \\ \mathrm{H} & -3.60172700 & -2.81381700 & -2.25032300 \\ \mathrm{H} & -3.96865700 & -2.69695800 & -0.53682600 \\ \mathrm{H} & -2.28724500 & -2.88674900 & -1.07049400 \\ \mathrm{C} & -4.53790000 & -0.33993700 & -1.57045500 \\ \mathrm{H} & -5.00729500 & -0.80300700 & -2.44574000 \\ \mathrm{H} & -4.54608100 & 0.74122900 & -1.73229000 \\ \mathrm{H} & -5.16521400 & -0.56611700 & -0.70777400 \\ \mathrm{C} & -2.86080600 & -0.54963900 & 1.67634100 \\ \mathrm{C} & -1.95426000 & 0.16938900 & 2.64553100 \\ \mathrm{H} & -1.95727300 & 1.25186900 & 2.48705100 \\ \mathrm{H} & -0.91988700 & -0.17659800 & 2.56414400 \\ \mathrm{H} & -2.29619200 & -0.02192700 & 3.66893900 \\ \mathrm{C} & -4.29912900 & -0.08794600 & 1.88676800 \\ \mathrm{H} & -5.00916300 & -0.66713400 & 1.29372000 \\ \mathrm{H} & -4.43453900 & 0.97352200 & 1.66226000 \\ \mathrm{H} & -4.55912500 & -0.23997500 & 2.94053900 \\ \mathrm{C} & -2.80412400 & -2.04380700 & 1.94223700 \\ \mathrm{H} & -3.01041400 & -2.20797400 & 3.00658800 \\ \mathrm{H} & -1.82543300 & -2.47474000 & 1.72042300 \\ \mathrm{H} & -3.55669700 & -2.59635700 & 1.38126600\end{array}$

\section{[2,6-( $\left.\left.{ }^{i} \mathrm{Pr}_{2} \mathrm{PO}\right)_{2} \mathrm{C}_{6} \mathrm{H}_{3}\right] \mathrm{NiCl}$}

$\begin{array}{rrrr}\mathrm{Ni} & 0.00284600 & -0.46681200 & -0.10107200 \\ \mathrm{Cl} & 0.02165400 & -2.64939900 & -0.32629800 \\ \mathrm{P} & 2.13888300 & -0.16239200 & -0.05404100 \\ \mathrm{P} & -2.13624400 & -0.20253700 & 0.04569100 \\ \mathrm{O} & 2.36878500 & 1.46526700 & 0.12887000 \\ \mathrm{O} & -2.39962500 & 1.43334300 & 0.02412000 \\ \mathrm{C} & -0.00973500 & 1.40734300 & 0.03694000 \\ \mathrm{C} & 1.16153400 & 2.16596000 & 0.09938200 \\ \mathrm{C} & 1.17845600 & 3.54698300 & 0.10589100 \\ \mathrm{H} & 2.12218500 & 4.07832100 & 0.13468400 \\ \mathrm{C} & -0.04162800 & 4.22121300 & 0.08083200 \\ \mathrm{H} & -0.05108400 & 5.30580900 & 0.08729500 \\ \mathrm{C} & -1.24394400 & 3.52551800 & 0.05828700 \\ \mathrm{H} & -2.19833900 & 4.03856100 & 0.05153300 \\ \mathrm{C} & -1.20363100 & 2.14470100 & 0.03921100 \\ \mathrm{C} & 3.20939200 & -0.48642600 & -1.50014500\end{array}$




\begin{tabular}{|c|c|c|c|}
\hline $\mathrm{H}$ & 4.15082500 & 0.03319800 & -1.28205900 \\
\hline $\mathrm{C}$ & 2.98353600 & -0.88907000 & 1.39372400 \\
\hline $\mathrm{H}$ & 3.00332400 & -1.96029900 & 1.15388700 \\
\hline $\mathrm{C}$ & -3.18971500 & -0.77939400 & -1.32661400 \\
\hline $\mathrm{H}$ & -3.15722800 & -1.87284100 & -1.25058300 \\
\hline $\mathrm{C}$ & -2.96262100 & -0.69531500 & 1.59631400 \\
\hline $\mathrm{H}$ & -3.93286200 & -0.18386200 & 1.59488300 \\
\hline $\mathrm{C}$ & 2.56863300 & 0.15471700 & -2.73743100 \\
\hline $\mathrm{H}$ & 3.23151200 & 0.04385000 & -3.60058500 \\
\hline $\mathrm{H}$ & 2.37959400 & 1.22037200 & -2.58590100 \\
\hline $\mathrm{H}$ & 1.61677800 & -0.33208100 & -2.97127600 \\
\hline $\mathrm{C}$ & 3.46725600 & -1.98131300 & -1.69235100 \\
\hline $\mathrm{H}$ & 2.52808000 & -2.53432800 & -1.78084300 \\
\hline $\mathrm{H}$ & 4.03761100 & -2.41183100 & -0.86524300 \\
\hline $\mathrm{H}$ & 4.04503400 & -2.13624900 & -2.60854400 \\
\hline $\mathrm{C}$ & 4.40610000 & -0.37631800 & 1.61487000 \\
\hline $\mathrm{H}$ & 4.40564400 & 0.70587300 & 1.77128700 \\
\hline $\mathrm{H}$ & 5.06320000 & -0.59887300 & 0.76978500 \\
\hline $\mathrm{H}$ & 4.83516600 & -0.84896000 & 2.50334700 \\
\hline $\mathrm{C}$ & 2.10119300 & -0.70749100 & 2.63327800 \\
\hline $\mathrm{H}$ & 2.57206100 & -1.17932800 & 3.50066200 \\
\hline $\mathrm{H}$ & 1.12137900 & -1.16618300 & 2.47888300 \\
\hline $\mathrm{H}$ & 1.95306600 & 0.35252500 & 2.86173900 \\
\hline $\mathrm{C}$ & -2.53963500 & -0.36424900 & -2.64691600 \\
\hline $\mathrm{H}$ & -3.12633400 & -0.74317600 & -3.48877200 \\
\hline $\mathrm{H}$ & -1.52416200 & -0.76235600 & -2.72700800 \\
\hline $\mathrm{H}$ & -2.49062600 & 0.72564100 & -2.73166600 \\
\hline $\mathrm{C}$ & -4.62520600 & -0.26968400 & -1.22738500 \\
\hline $\mathrm{H}$ & -4.64458800 & 0.82332800 & -1.21838300 \\
\hline $\mathrm{H}$ & -5.13672500 & -0.62919000 & -0.33032500 \\
\hline $\mathrm{H}$ & -5.19956600 & -0.61183800 & -2.09367200 \\
\hline $\mathrm{C}$ & -2.14568000 & -0.20987200 & 2.79688100 \\
\hline $\mathrm{H}$ & -2.67641700 & -0.43940400 & 3.72552400 \\
\hline $\mathrm{H}$ & -1.97157400 & 0.86867000 & 2.75869500 \\
\hline $\mathrm{H}$ & -1.17298800 & -0.70892900 & 2.82494900 \\
\hline $\mathrm{C}$ & -3.17178500 & -2.21882900 & 1.62171100 \\
\hline $\mathrm{H}$ & -2.22418200 & -2.74680100 & 1.48165100 \\
\hline $\mathrm{H}$ & -3.86541000 & -2.55258800 & 0.84605400 \\
\hline $\mathrm{H}$ & -3.58916500 & -2.51232400 & 2.58951800 \\
\hline
\end{tabular}

\section{[2,6- $\left.\left(\mathrm{Ph}_{2} \mathrm{PO}\right)_{2} \mathrm{C}_{6} \mathrm{H}_{3}\right] \mathrm{NiCl}$}

$\begin{array}{rrrr}\mathrm{Ni} & 0.00475500 & -0.06167800 & -0.09880500 \\ \mathrm{P} & 2.13538600 & 0.01699900 & 0.21902900\end{array}$




\begin{tabular}{|c|c|c|c|}
\hline $\mathrm{P}$ & -2.13636500 & -0.06143800 & 0.17259700 \\
\hline $\mathrm{Cl}$ & 0.05398700 & -0.12031300 & -2.28538900 \\
\hline $\mathrm{O}$ & 2.36191700 & 0.07450400 & 1.84857900 \\
\hline $\mathrm{O}$ & -2.38646700 & -0.20983600 & 1.79068800 \\
\hline $\mathrm{C}$ & 1.15084500 & -0.00157300 & 2.53397700 \\
\hline $\mathrm{C}$ & -0.01044800 & -0.05520000 & 1.78004000 \\
\hline $\mathrm{C}$ & -1.19311700 & -0.12739000 & 2.50744100 \\
\hline $\mathrm{C}$ & -1.23247100 & -0.14488500 & 3.88745900 \\
\hline $\mathrm{H}$ & -2.18634800 & -0.20226100 & 4.39839500 \\
\hline $\mathrm{C}$ & -0.04289000 & -0.09503800 & 4.57599400 \\
\hline $\mathrm{H}$ & -0.05609400 & -0.11322000 & 5.66087200 \\
\hline $\mathrm{C}$ & 1.16525100 & -0.02653300 & 3.91743200 \\
\hline $\mathrm{H}$ & 2.10879100 & 0.00771500 & 4.44865500 \\
\hline $\mathrm{C}$ & 3.13043500 & -1.39558200 & -0.28084500 \\
\hline $\mathrm{C}$ & 2.50734500 & -2.60009500 & -0.54061500 \\
\hline $\mathrm{H}$ & 1.42215300 & -2.65020600 & -0.52748300 \\
\hline $\mathrm{C}$ & 3.25340300 & -3.72080600 & -0.84467400 \\
\hline $\mathrm{H}$ & 2.74895900 & -4.65814900 & -1.05410000 \\
\hline $\mathrm{C}$ & 4.61591400 & -3.63974300 & -0.89639800 \\
\hline $\mathrm{H}$ & 5.20171800 & -4.51983100 & -1.14366400 \\
\hline $\mathrm{C}$ & 5.24432300 & -2.45285500 & -0.64282700 \\
\hline $\mathrm{H}$ & 6.32684900 & -2.38789800 & -0.68479500 \\
\hline $\mathrm{C}$ & 4.51156900 & -1.33338100 & -0.33166800 \\
\hline $\mathrm{H}$ & 5.01858600 & -0.39391500 & -0.13410500 \\
\hline $\mathrm{C}$ & 3.03433600 & 1.45559000 & -0.34929500 \\
\hline $\mathrm{C}$ & 3.30523600 & 2.52491200 & 0.47163300 \\
\hline $\mathrm{H}$ & 3.03657800 & 2.48082700 & 1.52206800 \\
\hline $\mathrm{C}$ & 3.91407100 & 3.65255100 & -0.04115600 \\
\hline $\mathrm{H}$ & 4.12116500 & 4.48583300 & 0.62299300 \\
\hline $\mathrm{C}$ & 4.26668800 & 3.71949700 & -1.35346400 \\
\hline $\mathrm{H}$ & 4.74787700 & 4.61153900 & -1.74234500 \\
\hline $\mathrm{C}$ & 3.99468200 & 2.67197600 & -2.17989900 \\
\hline $\mathrm{H}$ & 4.25699500 & 2.71469700 & -3.23186200 \\
\hline $\mathrm{C}$ & 3.39240800 & 1.53872500 & -1.68269500 \\
\hline $\mathrm{H}$ & 3.16691600 & 0.71454300 & -2.35291600 \\
\hline $\mathrm{C}$ & -3.14197700 & -1.41701000 & -0.46558100 \\
\hline $\mathrm{C}$ & -4.08448500 & -1.26353200 & -1.44479900 \\
\hline $\mathrm{H}$ & -4.29458700 & -0.27916700 & -1.85209300 \\
\hline $\mathrm{C}$ & -4.77867100 & -2.35361900 & -1.91807200 \\
\hline $\mathrm{H}$ & -5.52246800 & -2.20526200 & -2.69456800 \\
\hline $\mathrm{C}$ & -4.55891300 & -3.58666800 & -1.40887300 \\
\hline $\mathrm{H}$ & -5.12642000 & -4.43559300 & -1.77822800 \\
\hline $\mathrm{C}$ & -3.61645300 & -3.75867200 & -0.46100800 \\
\hline
\end{tabular}




$\begin{array}{lrrr}\mathrm{H} & -3.41264000 & -4.74355700 & -0.05313100 \\ \mathrm{C} & -2.90440200 & -2.68507800 & -0.00222600 \\ \mathrm{H} & -2.14586000 & -2.84130800 & 0.76085900 \\ \mathrm{C} & -3.02640500 & 1.45468300 & -0.23972400 \\ \mathrm{C} & -2.73541600 & 2.13529900 & -1.38302500 \\ \mathrm{H} & -1.96953700 & 1.75874700 & -2.05664200 \\ \mathrm{C} & -3.38602600 & 3.33184800 & -1.68309300 \\ \mathrm{H} & -3.12698400 & 3.85911400 & -2.59492400 \\ \mathrm{C} & -4.31182600 & 3.82477900 & -0.82574300 \\ \mathrm{H} & -4.81317100 & 4.76252900 & -1.04687000 \\ \mathrm{C} & -4.61482400 & 3.14602600 & 0.30078400 \\ \mathrm{H} & -5.35861000 & 3.53338700 & 0.99038900 \\ \mathrm{C} & -3.97651500 & 1.96481300 & 0.60804300 \\ \mathrm{H} & -4.21368400 & 1.44475000 & 1.53037700\end{array}$

\section{[2,6- $\left.\left(\mathrm{Me}_{2} \mathrm{PO}\right)_{2} \mathrm{C}_{6} \mathrm{H}_{3}\right] \mathrm{NiCl}$}

$\begin{array}{llll}\mathrm{Ni} & 0.01746400 & -0.74094600 & -0.00044000 \\ \mathrm{Cl} & 0.16968300 & -2.91385000 & -0.11790500 \\ \mathrm{P} & -2.12025500 & -0.53597800 & 0.02542000 \\ \mathrm{P} & 2.12649000 & -0.40048500 & 0.04191200 \\ \mathrm{O} & -2.42394200 & 1.09312500 & -0.01638200 \\ \mathrm{O} & 2.35195800 & 1.23347600 & -0.03159000 \\ \mathrm{C} & -0.02960600 & 1.13078700 & -0.00015100 \\ \mathrm{C} & -1.24381300 & 1.83689800 & -0.01219600 \\ \mathrm{C} & -1.30705500 & 3.22201400 & -0.03972100 \\ \mathrm{H} & -2.26856600 & 3.72119800 & -0.04402400 \\ \mathrm{C} & -0.11552000 & 3.93446500 & -0.07082000 \\ \mathrm{H} & -0.15040800 & 5.01866600 & -0.09735800 \\ \mathrm{C} & 1.12062200 & 3.29606900 & -0.08125000 \\ \mathrm{H} & 2.05280200 & 3.84617100 & -0.11180500 \\ \mathrm{C} & 1.12503300 & 1.90944700 & -0.03582100 \\ \mathrm{C} & -3.01946000 & -1.06069500 & 1.49576800 \\ \mathrm{H} & -4.06974200 & -0.76523500 & 1.43638000 \\ \mathrm{H} & -2.56140400 & -0.61283300 & 2.37896200 \\ \mathrm{H} & -2.94033200 & -2.14789500 & 1.57687300 \\ \mathrm{C} & -3.11964000 & -1.20176000 & -1.32270300 \\ \mathrm{H} & -4.17110300 & -0.92863000 & -1.20874700 \\ \mathrm{H} & -3.00691000 & -2.28895900 & -1.30612300 \\ \mathrm{H} & -2.74120500 & -0.83041800 & -2.27621700 \\ \mathrm{C} & 3.06939800 & -0.87010600 & 1.49850900 \\ \mathrm{H} & 4.10613100 & -0.53508100 & 1.41579000 \\ \mathrm{H} & 3.03289800 & -1.95821300 & 1.59457600 \\ \mathrm{H} & 2.60921300 & -0.42624500 & 2.38261400\end{array}$




$\begin{array}{llll}\mathrm{C} & 3.08902500 & -1.01687900 & -1.34251000 \\ \mathrm{H} & 4.13359300 & -0.70373100 & -1.27480800 \\ \mathrm{H} & 2.65207800 & -0.64668000 & -2.27126000 \\ \mathrm{H} & 3.01778900 & -2.10746500 & -1.33898800\end{array}$

\section{[2,6- $\left.\left({ }^{i} \mathrm{Pr}_{2} \mathrm{PO}\right)_{2} \mathrm{C}_{6} \mathrm{H}_{3}\right] \mathrm{NiF}$}

\begin{tabular}{|c|c|c|c|}
\hline $\mathrm{Ni}$ & 0.01809300 & -0.49922200 & 0.03248700 \\
\hline $\mathrm{P}$ & -2.13812800 & -0.34854500 & 0.03042600 \\
\hline $\mathrm{P}$ & 2.13339900 & -0.07636200 & 0.04978100 \\
\hline $\mathrm{C}$ & -0.09827700 & 1.36444000 & -0.13742800 \\
\hline $\mathrm{C}$ & 1.03537600 & 2.17793300 & -0.20022000 \\
\hline $\mathrm{C}$ & -1.32524600 & 2.03506700 & -0.19750900 \\
\hline $\mathrm{C}$ & -0.27074600 & 4.16280800 & -0.34068100 \\
\hline $\mathrm{H}$ & -0.33708100 & 5.24296000 & -0.41536200 \\
\hline $\mathrm{C}$ & -1.43822200 & 3.40879900 & -0.28321700 \\
\hline $\mathrm{H}$ & -2.41727000 & 3.87170500 & -0.31825800 \\
\hline $\mathrm{C}$ & 0.97662000 & 3.55656700 & -0.30310200 \\
\hline $\mathrm{H}$ & 1.89177200 & 4.13509500 & -0.34850700 \\
\hline $\mathrm{C}$ & 3.20386700 & -0.73618800 & -1.27782200 \\
\hline $\mathrm{H}$ & 4.18972100 & -0.27160700 & -1.15890300 \\
\hline $\mathrm{C}$ & 2.61734000 & -0.32757400 & -2.63355300 \\
\hline $\mathrm{H}$ & 3.27154800 & -0.67083700 & -3.44057300 \\
\hline $\mathrm{H}$ & 2.51006300 & 0.75669600 & -2.71454600 \\
\hline $\mathrm{H}$ & 1.63163700 & -0.78108800 & -2.77750900 \\
\hline $\mathrm{C}$ & 4.49976200 & -0.05685100 & 1.57123300 \\
\hline $\mathrm{H}$ & 4.92897500 & -0.02621100 & 2.57794300 \\
\hline $\mathrm{H}$ & 4.72749300 & 0.89402400 & 1.08218300 \\
\hline $\mathrm{H}$ & 5.00735500 & -0.85817000 & 1.02540900 \\
\hline $\mathrm{C}$ & 3.31207800 & -2.26403000 & -1.14016100 \\
\hline $\mathrm{H}$ & 2.31704300 & -2.71259500 & -1.04664800 \\
\hline $\mathrm{H}$ & 3.89450300 & -2.55454100 & -0.26231100 \\
\hline $\mathrm{H}$ & 3.80684200 & -2.67925700 & -2.02274200 \\
\hline $\mathrm{C}$ & 3.00020600 & -0.30737200 & 1.65699500 \\
\hline $\mathrm{H}$ & 2.55583000 & 0.53270000 & 2.21220000 \\
\hline $\mathrm{C}$ & 2.65753600 & -1.55834700 & 2.36945500 \\
\hline $\mathrm{H}$ & 3.14917400 & -2.43115000 & 1.92831500 \\
\hline $\mathrm{H}$ & 1.58421300 & -1.76735700 & 2.34403100 \\
\hline $\mathrm{H}$ & 2.98034500 & -1.49980300 & 3.41403000 \\
\hline $\mathrm{C}$ & -3.02198700 & -1.12356600 & -1.36222700 \\
\hline $\mathrm{H}$ & -4.04907900 & -0.73934300 & -1.34678600 \\
\hline $\mathrm{C}$ & -3.05103700 & -0.77373300 & 1.54668200 \\
\hline $\mathrm{H}$ & -2.85529500 & -1.84608100 & 1.67622500 \\
\hline $\mathrm{C}$ & -3.01838300 & -2.64589900 & -1.18279600 \\
\hline
\end{tabular}




$\begin{array}{lrrr}\mathrm{H} & -3.41659100 & -3.12509600 & -2.08172100 \\ \mathrm{H} & -3.63367900 & -2.96174200 & -0.33572900 \\ \mathrm{H} & -1.99764500 & -3.00729500 & -1.01480300 \\ \mathrm{C} & -4.55165200 & -0.52020000 & 1.44961700 \\ \mathrm{H} & -5.03006200 & -0.74978800 & 2.40674700 \\ \mathrm{H} & -5.03079100 & -1.13746800 & 0.68541300 \\ \mathrm{H} & -4.75103500 & 0.53008600 & 1.21793000 \\ \mathrm{C} & -2.42591400 & -0.01964600 & 2.72287200 \\ \mathrm{H} & -2.56693100 & 1.05927400 & 2.60913100 \\ \mathrm{H} & -1.35196200 & -0.21423800 & 2.79332500 \\ \mathrm{H} & -2.89677400 & -0.32791500 & 3.66061400 \\ \mathrm{C} & -2.35783200 & -0.71348100 & -2.67808000 \\ \mathrm{H} & -1.33197000 & -1.09287100 & -2.72224000 \\ \mathrm{H} & -2.32482800 & 0.37298900 & -2.79253000 \\ \mathrm{H} & -2.91472000 & -1.13140000 & -3.52191200 \\ \mathrm{O} & -2.48717700 & 1.26015100 & -0.16938100 \\ \mathrm{O} & 2.28605900 & 1.55214700 & -0.16376800 \\ \mathrm{~F} & 0.13017300 & -2.32317700 & 0.19552000\end{array}$

\section{$\left[2,6-\left({ }^{i} \mathrm{Pr}_{2} \mathrm{PO}\right)_{2} \mathrm{C}_{6} \mathrm{H}_{3}\right] \mathrm{NiBr}$}

$\begin{array}{rrrr}\mathrm{Ni} & -0.00626200 & -0.25106300 & -0.02794200 \\ \mathrm{Br} & 0.08744700 & -2.57220100 & -0.01926900 \\ \mathrm{P} & -2.14537700 & -0.00477800 & -0.06246200 \\ \mathrm{P} & 2.11082100 & 0.06331200 & 0.06247800 \\ \mathrm{O} & -2.41346000 & 1.63587300 & -0.10661800 \\ \mathrm{O} & 2.35248500 & 1.69616100 & -0.02600500 \\ \mathrm{C} & 1.15052400 & 2.39226500 & -0.05648100 \\ \mathrm{C} & -0.02884300 & 1.63384700 & -0.06790100 \\ \mathrm{C} & -1.22137400 & 2.34997200 & -0.09894600 \\ \mathrm{C} & -1.26864800 & 3.73685500 & -0.15085500 \\ \mathrm{H} & -2.22301300 & 424816700 & -0.18627400 \\ \mathrm{C} & -0.06310500 & 4.43501200 & -0.13222900 \\ \mathrm{H} & -0.07885400 & 5.51941100 & -0.16212100 \\ \mathrm{C} & 1.16155000 & 3.77304800 & -0.09199200 \\ \mathrm{H} & 2.10118700 & 4.31213100 & -0.08377000 \\ \mathrm{C} & -3.05641400 & -0.53495500 & 1.42131400 \\ \mathrm{H} & -3.06828400 & -1.62951500 & 1.35146800 \\ \mathrm{C} & -3.11177200 & -0.55272100 & -1.51052900 \\ \mathrm{H} & -4.03881600 & 0.03320300 & -1.48355800 \\ \mathrm{C} & 2.98438800 & -0.33552100 & 1.61973700 \\ \mathrm{H} & 3.90485900 & 0.26174800 & 1.57481700 \\ \mathrm{C} & 3.12000800 & -0.58928500 & -1.30360200 \\ \mathrm{H} & 3.05092400 & -1.67648200 & -1.17090000\end{array}$




\begin{tabular}{|c|c|c|c|}
\hline $\mathrm{C}$ & -4.47342800 & 0.02187000 & 1.47081500 \\
\hline $\mathrm{H}$ & -4.97355400 & -0.31242400 & 2.38495800 \\
\hline $\mathrm{H}$ & -5.08273700 & -0.30508200 & 0.62340300 \\
\hline $\mathrm{H}$ & -4.45592300 & 1.11485600 & 1.47420100 \\
\hline $\mathrm{C}$ & -2.26283800 & -0.13170200 & 2.66934300 \\
\hline $\mathrm{H}$ & -2.16263000 & 0.95612500 & 2.73257500 \\
\hline $\mathrm{H}$ & -1.26016800 & -0.56681400 & 2.65536000 \\
\hline $\mathrm{H}$ & -2.77879400 & -0.47799100 & 3.56953300 \\
\hline $\mathrm{C}$ & -3.43366500 & -2.04904600 & -1.46851800 \\
\hline $\mathrm{H}$ & -3.94651000 & -2.33431100 & -2.39188900 \\
\hline $\mathrm{H}$ & -4.08786800 & -2.30776700 & -0.63182100 \\
\hline $\mathrm{H}$ & -2.51981500 & -2.64358300 & -1.38624500 \\
\hline $\mathrm{C}$ & -2.32177600 & -0.18299200 & -2.77251600 \\
\hline $\mathrm{H}$ & -1.39268500 & -0.75903900 & -2.81895900 \\
\hline $\mathrm{H}$ & -2.06668900 & 0.87985300 & -2.79356800 \\
\hline $\mathrm{H}$ & -2.91262700 & -0.40997700 & -3.66489600 \\
\hline $\mathrm{C}$ & 3.33453200 & -1.80772300 & 1.73361900 \\
\hline $\mathrm{H}$ & 3.83240000 & -1.99126800 & 2.69103700 \\
\hline $\mathrm{H}$ & 4.01153900 & -2.13855500 & 0.94191100 \\
\hline $\mathrm{H}$ & 2.43743600 & -2.43112800 & 1.69109300 \\
\hline $\mathrm{C}$ & 2.14634900 & 0.15723200 & 2.80810700 \\
\hline $\mathrm{H}$ & 1.22482500 & -0.42645700 & 2.88963000 \\
\hline $\mathrm{H}$ & 1.87667200 & 1.21145900 & 2.70473700 \\
\hline $\mathrm{H}$ & 2.71228100 & 0.03711200 & 3.73659100 \\
\hline $\mathrm{C}$ & 2.47247600 & -0.22054000 & -2.63703900 \\
\hline $\mathrm{H}$ & 2.46455200 & 0.86435300 & -2.77981700 \\
\hline $\mathrm{H}$ & 1.44075100 & -0.57952700 & -2.68950000 \\
\hline $\mathrm{H}$ & 3.03505100 & -0.66744000 & -3.46164400 \\
\hline $\mathrm{C}$ & 4.57646000 & -0.13176100 & -1.26477800 \\
\hline $\mathrm{H}$ & 5.11763000 & -0.55124900 & -2.11818900 \\
\hline $\mathrm{H}$ & 5.09569500 & -0.44868200 & -0.35645700 \\
\hline $\mathrm{H}$ & 4.63746700 & 0.95826400 & -1.32945300 \\
\hline \multicolumn{4}{|c|}{$\left.-\left({ }^{i} \mathrm{Pr}_{2} \mathrm{PO}\right)_{2} \mathrm{C}_{6} \mathrm{H}_{3}\right] \mathrm{NiI}$} \\
\hline $\mathrm{Ni}$ & -0.03113600 & -0.05675200 & 0.02083900 \\
\hline $\mathrm{I}$ & 0.04532800 & -2.54720600 & -0.01997800 \\
\hline $\mathrm{P}$ & -2.17010200 & 0.19364100 & 0.08385400 \\
\hline $\mathrm{P}$ & 2.09190300 & 0.25012500 & -0.02106000 \\
\hline $\mathrm{O}$ & -2.42852000 & 1.83533500 & 0.07918800 \\
\hline $\mathrm{O}$ & 2.32376600 & 1.88918000 & 0.00099000 \\
\hline $\mathrm{C}$ & -1.24173500 & 2.55682600 & 0.01591600 \\
\hline $\mathrm{C}$ & -0.06173300 & 1.82255000 & 0.02696200 \\
\hline $\mathrm{C}$ & 1.11527700 & 2.56974200 & -0.02583500 \\
\hline
\end{tabular}




\begin{tabular}{|c|c|c|c|}
\hline $\mathrm{C}$ & 1.11713700 & 3.97284800 & -0.05261300 \\
\hline $\mathrm{H}$ & 2.06241700 & 4.50196300 & -0.08320800 \\
\hline $\mathrm{C}$ & -0.07613400 & 4.61942200 & -0.04519800 \\
\hline $\mathrm{H}$ & -0.09462600 & 5.70469300 & -0.06437200 \\
\hline $\mathrm{C}$ & -1.27840200 & 3.93298600 & 0.00494500 \\
\hline $\mathrm{H}$ & -2.23030700 & 4.45009100 & 0.01846900 \\
\hline $\mathrm{C}$ & -3.09612400 & -0.28257100 & 1.58455400 \\
\hline $\mathrm{H}$ & -3.99908600 & 0.34183500 & 1.54036700 \\
\hline $\mathrm{C}$ & -3.12068900 & -0.36285800 & -1.35436800 \\
\hline $\mathrm{H}$ & -3.16039100 & -1.45397500 & -1.24978200 \\
\hline $\mathrm{C}$ & 3.06037600 & -0.19432100 & -1.51724500 \\
\hline $\mathrm{H}$ & 3.92623400 & 0.47759300 & -1.46206900 \\
\hline $\mathrm{C}$ & -3.51188800 & -1.75443000 & 1.58342700 \\
\hline $\mathrm{H}$ & -2.64227000 & -2.41319800 & 1.51730800 \\
\hline $\mathrm{H}$ & -4.18516200 & -1.99143000 & 0.75595300 \\
\hline $\mathrm{H}$ & -4.03939500 & -1.98011400 & 2.51528200 \\
\hline $\mathrm{C}$ & -2.30214600 & 0.10607400 & 2.80983500 \\
\hline $\mathrm{H}$ & -2.89521100 & -0.06420100 & 3.71364200 \\
\hline $\mathrm{H}$ & -2.01371900 & 1.16067700 & 2.78949000 \\
\hline $\mathrm{H}$ & -1.38860900 & -0.49239000 & 2.88574000 \\
\hline $\mathrm{C}$ & -2.36869900 & -0.02078300 & -2.64350900 \\
\hline $\mathrm{H}$ & -2.92314700 & -0.39791900 & -3.50734900 \\
\hline $\mathrm{H}$ & -1.36994900 & -0.46610100 & -2.65242600 \\
\hline $\mathrm{H}$ & -2.26156000 & 1.06256700 & -2.75457700 \\
\hline $\mathrm{C}$ & -4.52056100 & 0.23213000 & -1.40620300 \\
\hline $\mathrm{H}$ & -4.47018900 & 1.32247400 & -1.46095700 \\
\hline $\mathrm{H}$ & -5.12735700 & -0.03422600 & -0.53566400 \\
\hline $\mathrm{H}$ & -5.04451100 & -0.13001400 & -2.29575600 \\
\hline $\mathrm{C}$ & 3.53734700 & -1.63843100 & -1.51986600 \\
\hline $\mathrm{H}$ & 2.69927700 & -2.33668900 & -1.45605800 \\
\hline $\mathrm{H}$ & 4.22524900 & -1.85482400 & -0.70028400 \\
\hline $\mathrm{H}$ & 4.06949000 & -1.83852200 & -2.45591400 \\
\hline $\mathrm{C}$ & 2.24194200 & 0.17476200 & -2.72834200 \\
\hline $\mathrm{H}$ & 2.82600400 & 0.05020800 & -3.64642800 \\
\hline $\mathrm{H}$ & 1.90434200 & 1.21442500 & -2.68729300 \\
\hline $\mathrm{H}$ & 1.35575000 & -0.46362100 & -2.80762800 \\
\hline $\mathrm{C}$ & 3.23863500 & -0.27787800 & 1.31536800 \\
\hline $\mathrm{H}$ & 3.26010800 & -1.37106300 & 1.23579800 \\
\hline $\mathrm{C}$ & 4.63593100 & 0.30115800 & 1.20951800 \\
\hline $\mathrm{H}$ & 4.60071700 & 1.39397900 & 1.19813200 \\
\hline $\mathrm{H}$ & 5.17425500 & -0.03207400 & 0.31925900 \\
\hline $\mathrm{H}$ & 5.22046600 & -0.00732100 & 2.08196400 \\
\hline $\mathrm{C}$ & 2.58809700 & 0.10380400 & 2.61843400 \\
\hline
\end{tabular}




$\begin{array}{llrl}\mathrm{H} & 3.19089500 & -0.22859600 & 3.47006900 \\ \mathrm{H} & 1.59381000 & -0.34234200 & 2.71692800 \\ \mathrm{H} & 2.47709100 & 1.19029800 & 2.69872800\end{array}$

\section{REFERENCES}

(S1) (a) Benito-Garagorri, D.; Bocokić, V.; Mereiter, K.; Kirchner, K. A Modular Approach to Achiral and Chiral Nickel(II), Palladium(II), and Platinum(II) PCP Pincer Complexes Based on Diaminobenzenes. Organometallics 2006, 25, 3817-3823. (b) Ozerov, O. V.; Guo, C.; Foxman, B. M. Missing link: PCP pincer ligands containing $\mathrm{P}-\mathrm{N}$ bonds and their $\mathrm{Pd}$ complexes. $J$. Organomet. Chem. 2006, 691, 4802-4806.

(S2) (a) Sheldrick, G. M. A Short History of SHELX. Acta Crystallogr Sect. A: Found. Crystallogr. 2008, 64, 112-122. (b) Dolomanov, O. V.; Bourhis, L. J.; Gildea, R. J.; Howard, J. A. K.; Puschmann, H. OLEX 2 : a Complete Structure Solution, Refinement and Analysis Program. $J$. Appl. Crystallogr. 2009, 42, 339-341.

(S3) (a) Boro, B. J.; Dickie, D. A.; Goldberg, K. I.; Kemp, R. A. \{2,6-Bis[(di-tert-butylphosphino) methyl]phenyl\}chloridonickel(II). Acta Cryst. 2008, E64, m1304. (b) Benito-Garagorri, D.; Bocokić, V.; Mereiter, K.; Kirchner, K. A Modular Approach to Achiral and Chiral Nickel(II), Palladium(II), and Platinum(II) PCP Pincer Complexes Based on Diaminobenzenes. Organometallics 2006, 25, 3817-3823. (c) Chakraborty, S.; Krause, J. A.; Guan, H. Hydrosilylation of Aldehydes and Ketones Catalyzed by Nickel PCP-Pincer Hydride Complexes. Organometallics 2009, 28, 582-586. (d) Valderrama-García, B. X.; Rufino-Felipe, E.; Valdés, H.; Hernandez-Ortega, S.; Aguilar-Castillo, B. A.; Morales-Morales, D. Novel and Facile Procedure for the Synthesis of Ni(II) and Pd(II) PSCOP Pincer Complexes. Evaluation of Their Catalytic Activity on C-S, C-Se and C-C Cross Coupling Reactions. Inorg. Chim. Acta 2020, 502, 119283. 
(e) Pandarus, V.; Zargarian, D. New Pincer-Type Diphosphinito (POCOP) Complexes of Nickel. Organometallics 2007, 26, 4321-4334. (f) Gómez-Benítez, V.; Baldovino-Pantaleón, O.; Herrera-Álvarez, C.; Toscano, R. A.; Morales-Morales, D. High Yield Thiolation of Iodobenzene Catalyzed by the Phosphinite Nickel PCP Pincer Complex: [NiCl $\left.\left\{\mathrm{C}_{6} \mathrm{H}_{3}-2,6-\left(\mathrm{OPPh}_{2}\right)_{2}\right\}\right]$. Tetrahedron Lett. 2006, 47, 5059-5062. (g) Duncan, D.; Hope, E. G.; Singh, K.; Stuart, A. M. A Recyclable Perfluoroalkylated PCP Pincer Palladium Complex. Dalton Trans. 2011, 40, 19982005. (h) Vabre, B.; Petiot, P.; Declercq, R.; Zargarian, D. Fluoro and Trifluoromethyl Derivatives of POCOP-Type Pincer Complexes of Nickel: Preparation and Reactivities in $\mathrm{S}_{\mathrm{N}} 2$ Fluorination and Direct Benzylation of Unactivated Arenes. Organometallics 2014, 33, 51735184. (i) Pandarus, V.; Zargarian, D. New Pincer-Type Diphosphinito (POCOP) Complexes of $\mathrm{Ni}^{\mathrm{II}}$ and $\mathrm{Ni}{ }^{\mathrm{III}}$. Chem. Commun. 2007, 978-980.

(S4) Frisch, M. J.; Trucks, G. W.; Schlegel, H. B.; Scuseria, G. E.; Robb, M. A.; Cheeseman, J. R.; Scalmani, G.; Barone, V.; Petersson, G. A.; Nakatsuji, H.; Li, X.; Caricato, M.; Marenich, A.; Bloino, J.; Janesko, B. G.; Gomperts, R.; Mennucci, B.; Hratchian, H. P.; Ortiz, J. V.; Izmaylov, A. F.; Sonnenberg, J. L. Williams-Young, D.; Ding, F.; Lipparini, F.; Egidi, F.; Goings, J.; Peng, B.; Petrone, A.; Henderson, T.; Ranasinghe, D.; Zakrzewski, V. G.; Gao, J.; Rega, N.; Zheng, G.; Liang, W.; Hada, M.; Ehara, M.; Toyota, K.; Fukuda, R.; Hasegawa, J.; Ishida, M.; Nakajima, T.; Honda, Y.; Kitao, O.; Nakai, H.; Vreven, T.; Throssell, K.; Montgomery Jr., J. A.; Peralta, J. E.; Ogliaro, F.; Bearpark, M.; Heyd, J. J.; Brothers, E.; Kudin, K. N.; Staroverov, V. N.; Keith, T.; Kobayashi, R.; Normand, J.; Raghavachari, K.; Rendell, A.; Burant, J. C.; Iyengar, S. S.; Tomasi, J.; Cossi, M.; Millam, J. M.; Klene, M.; Adamo, C.; Cammi, R.; Ochterski, J. W.; Martin, R. L.; 
Morokuma, K.; Farkas, O.; Foresman, J. B.; Fox, D. J. Gaussian 09, Revision D.01, Gaussian, Inc., Wallingford, CT, 2009.

(S5) (a) Adamo, C.; Barone, V. Toward Reliable Density Functional Methods without Adjustable Parameters: The PBE0 model. J. Chem. Phys. 1999, 110, 6158-6170. (b) Perdew, J. P.; Burke, K.; Ernzerhof, M. Generalized Gradient Approximation Made Simple. Phys. Rev. Lett. 1996, 77, 3865-3868. (c) Grimme, S.; Antony, J.; Ehrlich, S.; Krieg, H. A Consistent and Accurate Ab initio Parametrization of Density Functional Dispersion Correction (DFT-D) for the 94 Elements H-Pu. J. Chem. Phys. 2010, 132, 154104. (d) Johnson, E, R.; Becke, A, D. A Post-Hartree-Fock Model of Intermolecular Interactions: Inclusion of Higher-Order Corrections. J. Chem. Phys. 2006, 124, 174104.

(S6) Schuchardt, K. L.; Didier, B. T.; Elsethagen, T.; Sun, L.; Gurumoorthi, V.; Chase, J.; Li, J.; Windus, T. L. Basis Set Exchange: A Community Database for Computational Sciences. J. Chem. Inf. Model. 2007, 47, 1045-1052.

(S7) Lu, T.; Chen, F. Multiwfn: A Multifunctional Wavefunction Analyzer. J. Comput. Chem. 2012, $33,580-592$. 